\title{
LOW-TEMPERATURE GEOTHERMAL ASSESSMENT OF THE SANTA CLARA AND VIRGIN RIVER VALLEYS, WASHINGTON COUNTY, UTAH
}

By Karin E. Budding and Steven N. Sommer

Work Performed Under Contract No.DE-FG07-84ID12543

Prepared for the U. S. Department of Energy

Idaho Operations Office, Idaho Falls, ID

UTAH GEOLOGICAL AND MINERAL SURVEY

a division of

UTAH DEPARTMENT OF NATURAL RESOURCES

SPECIAL STUDIES 67

1986

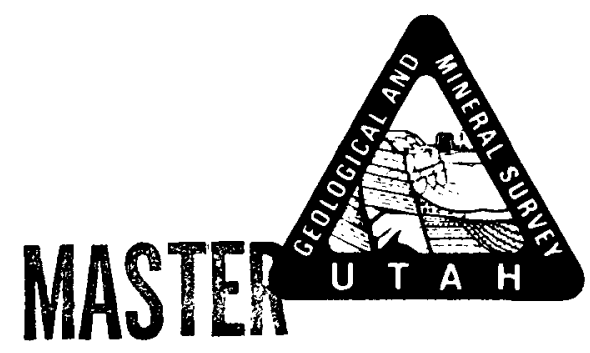




\section{DISCLAIMER}

This report was prepared as an account of work sponsored by an agency of the United States Government. Neither the United States Government nor any agency Thereof, nor any of their employees, makes any warranty, express or implied, or assumes any legal liability or responsibility for the accuracy, completeness, or usefulness of any information, apparatus, product, or process disclosed, or represents that its use would not infringe privately owned rights. Reference herein to any specific commercial product, process, or service by trade name, trademark, manufacturer, or otherwise does not necessarily constitute or imply its endorsement, recommendation, or favoring by the United States Government or any agency thereof. The views and opinions of authors expressed herein do not necessarily state or reflect those of the United States Government or any agency thereof. 


\section{DISCLAIMER}

Portions of this document may be illegible in electronic image products. Images are produced from the best available original document. 
STATE OF UTAH

Norman H. Bangerter, Governor

DEPARTMENT OF NATURAL RESOURCES

Dee C. Hansen, Executive Director

\title{
UTAH GEOLOGICAL AND MINERAL SURVEY Genevieve Atwood, Director
}

\begin{abstract}
BOARD

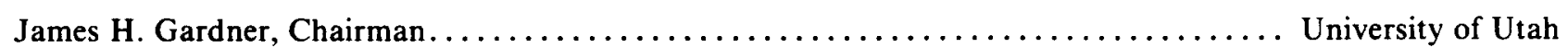

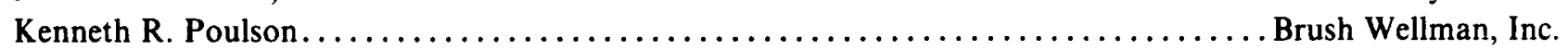

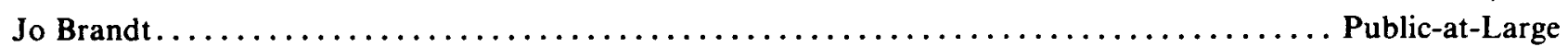

Robert L. Haffner .............................. American Gilsonite/Chevron Resources

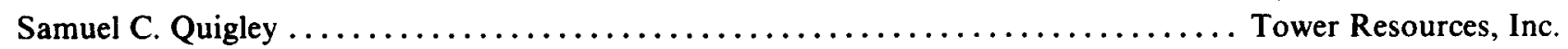

Lawrence Reaveley $\ldots \ldots \ldots \ldots \ldots \ldots \ldots \ldots \ldots \ldots \ldots \ldots \ldots \ldots \ldots \ldots$ Reaveley Engineers \& Associates

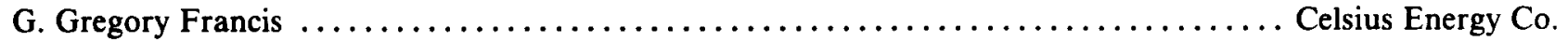

Ralph A Miles, Director, Division of State Lands ..................... exficio member
\end{abstract}

\section{UGMS Editorial aNd Illustrations StafF}

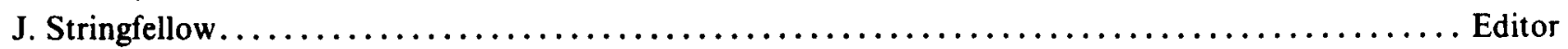
Leigh M. MacManus, Carolyn M. Olsen $\ldots \ldots \ldots \ldots \ldots \ldots \ldots \ldots \ldots \ldots \ldots \ldots \ldots \ldots \ldots$ Editorial Staff Kent D. Brown, James W. Parker, Patricia H. Speranza ..................... Cartographers

\section{DISCLAIMER}

This book was prepared as an account of work sponsored by an agency of the United States Government. Neither the United States Government nor any agency thereof, nor any of their employees, makes any warranty, express or implied, or assumes any legal liability or responsibility for the accuracy, completeness, or usefulness of any information, apparatus, product or process disclosed, or represents that its use would not infringe privately owned rights. References herein to any specific commercial product, process, or service by trade name, trademark, manufacturer, or otherwise, does not necessarily constitute or imply its endorsement, recommendation, or favoring by the United States Government or any agency thereof. The views and opinions of authors expressed herein do not necessarily state or reflect those of the United States Government or any agency thereof. 


\section{LOW-TEMPERATURE GEOTHERMAL ASSESSMENT OF THE SANTA CLARA AND VIRGIN RIVER VALLEYS, WASHINGTON COUNTY, UTAH}

By Karin E. Budding and Steven N. Sommer

UTAH GEOLOGICAL AND MINERAL SURVEY

a division of

UTAH DEPARTMENT OF NATURAL RESOURCES

SPECIAL STUDIES 67

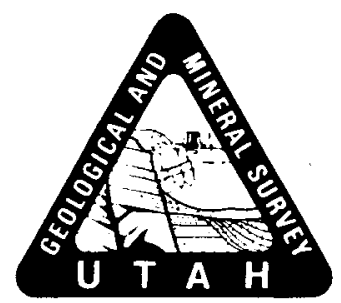




\section{TABLE OF CONTENTS}

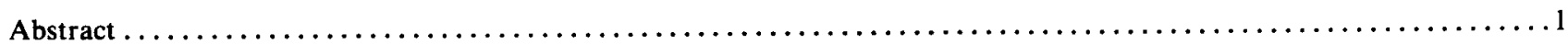

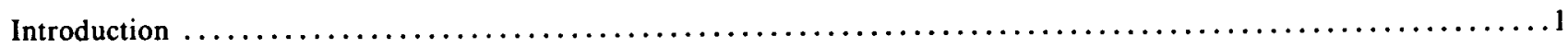

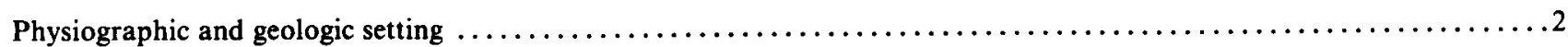

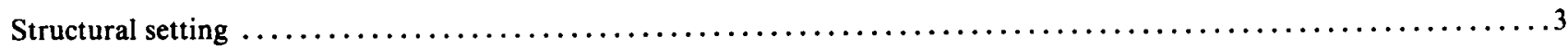

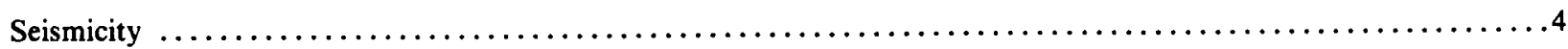

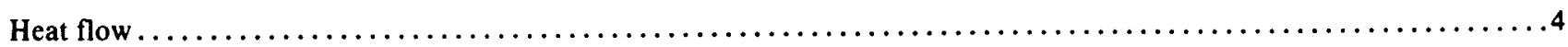

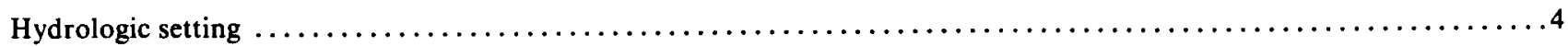

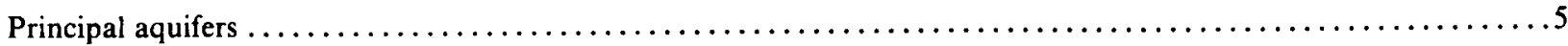

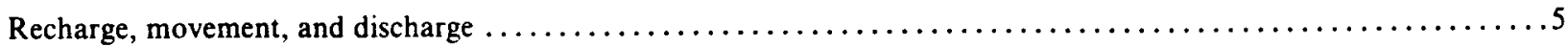

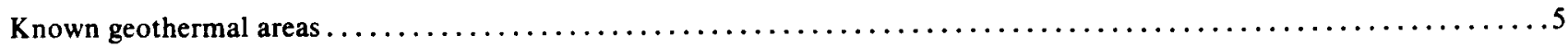

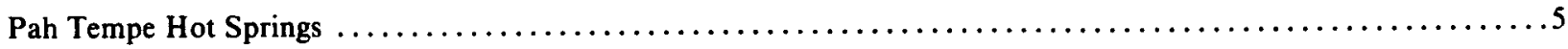

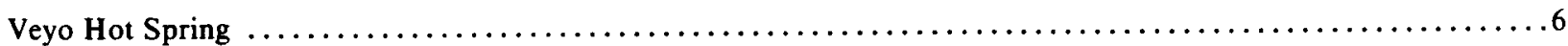

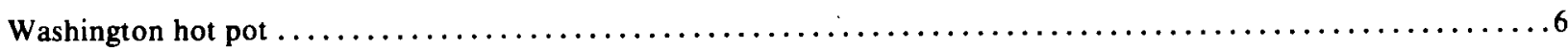

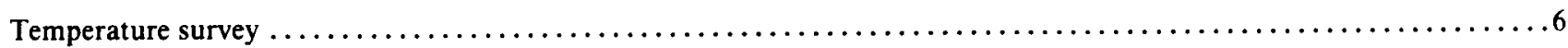

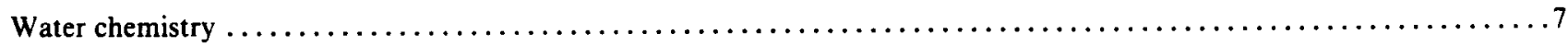

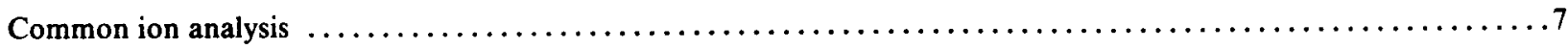

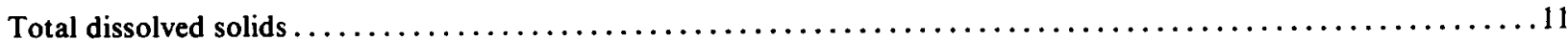

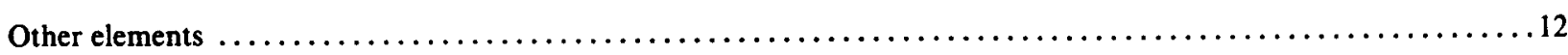

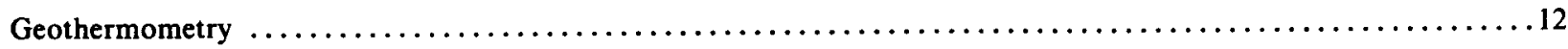

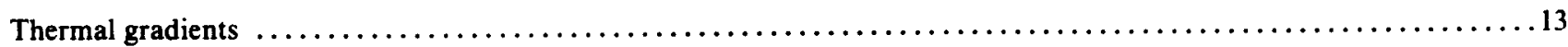

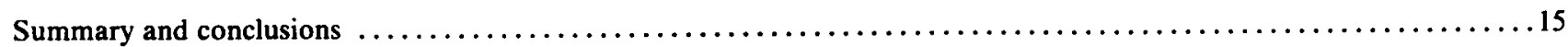

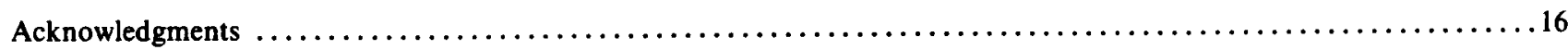

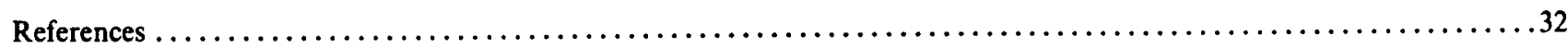

\section{ILLUSTRATIONS}

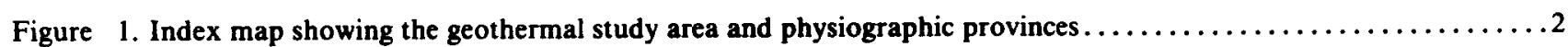

2. Heat flow map of Utah from Lachenbruch and Sass (1980) showing measurements taken in the

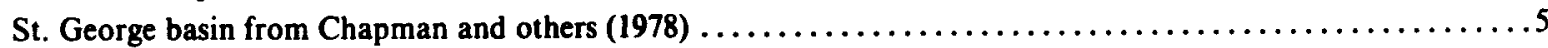

3. Map showing locations, temperatures (in ${ }^{\circ} \mathrm{C}$ ), and calculated TDS values (in ppm) of spring and well samples in the St. George basin, and locations of temperature-depth

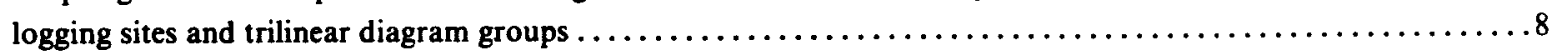

4. Piper diagram showing nomenclature used to describe water samples from Back (1961)

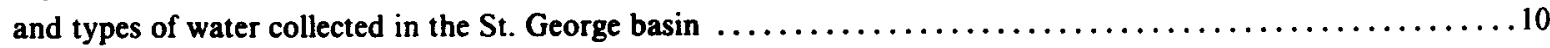

5. Piper diagram of common ions in samples collected from the northwestern

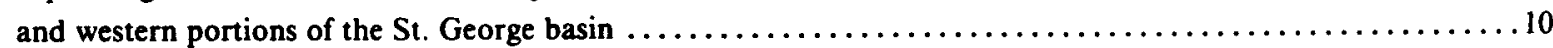

6. Piper diagram of common ions in samples collected from the west-central portion

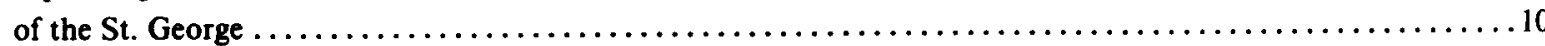

7. Piper diagram of common ions in samples collected from the central portion of the St. George basin .

8. Piper diagram of common ions in samples collected from the south-central portion of the St. George basin 


\section{TABLE OF CONTENTS}

9. Piper diagram of common ions in samples collected from the southeastern portion

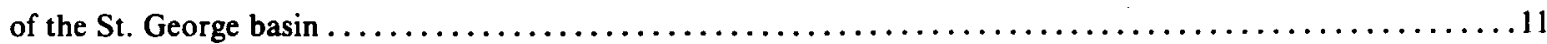

10. Piper diagram of common ions in samples collected from the northeastern portion

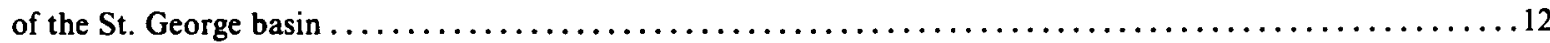

11. Temperature-depth profiles TG1, TG3, and TG14 logged south of Washington Fields

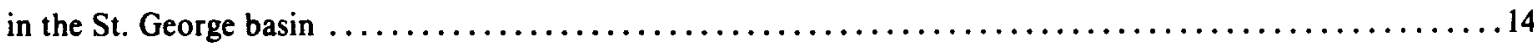

12. Temperature-depth profiles TG4, TG5, TG7, and TG15 logged south of Washington Fields

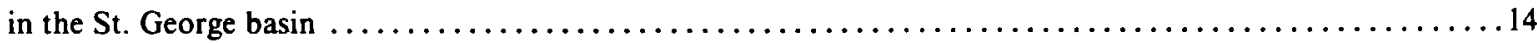

13. Temperature-depth profiles TG9 through TG13 logged south of Berry Springs

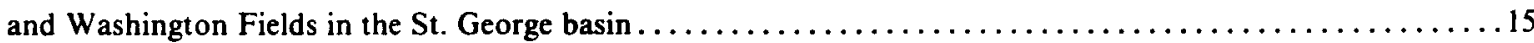

14. Temperature-depth profiles TG2, TG8, TG11, TG16, and TG18 logged in scattered

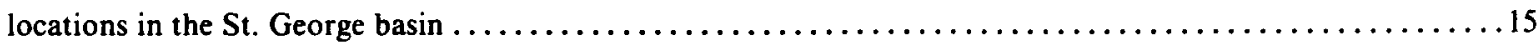

15. Temperature-depth profile TG6 logged southeast of Veyo in the

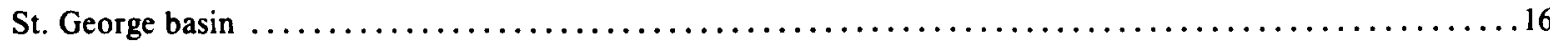

\section{TABLES}

Table 1. Chemical analyses of spring and well water samples collected in the study area

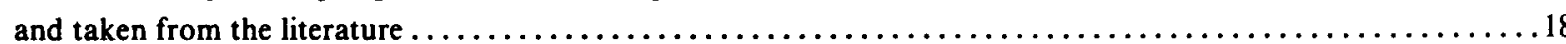

2. Calculated chemical geothermometer temperatures and surface temperatures $\left(\right.$ in ${ }^{\circ} \mathrm{C}$ ) for spring

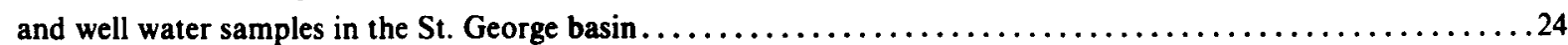

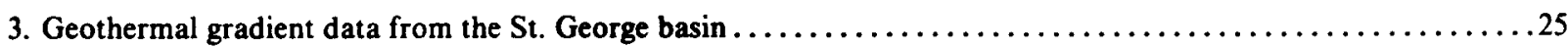

4. Temperature-depth profile data for TG1 through TG16 and TG18, St. George Basin ...............26

\section{PLATE}

Plate 1. Geologic map of the St. George basin modified from Hamblin (1986; in press, a and b) and Cook (1960) unless indicated otherwise. (Includes locations of Pah Temple and Veyo Hot Spring and

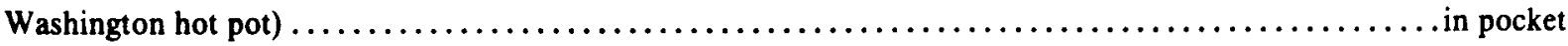




\title{
LOW-TEMPERATURE GEOTHERMAL ASSESSMENT OF THE SANTA CLARA AND VIRGIN RIVER VALLEYS, WASHINGTON COUNTY, UTAH
}

\author{
By Karin E. Budding and Steven N. Sommer
}

\begin{abstract}
The low-temperature geothermal assessment of the Santa Clara and Virgin River Valleys and surrounding terrain was funded jointly by the U.S. Department of Energy (grant no. DE-FG07-84ID12543) and the Utah Geological and Mineral Survey (UGMS). Exploration techniques employed included the following: 1) a temperature survey of springs, 2) chemical analyses and calculated geothermometer temperatures of water samples collected from selected springs and wells, 3) chemical analyses and calculated geothermometer temperatures of spring and well water samples in the literature, 4) thermal gradients measured in accessible wells, and 5) geology.

The highest water temperature recorded in the St. George basin is $42^{\circ} \mathrm{C}$ at $\mathrm{Pah}$ Tempe Hot Springs. Additional spring temperatures higher than $20^{\circ} \mathrm{C}$ are at Veyo Hot Spring, Washington hot pot, and Green Spring. The warmest well water in the study area is $40^{\circ} \mathrm{C}$ in Middleton Wash. Additional warm well water (higher than $24.5^{\circ} \mathrm{C}$ ) is present north of St. George, north of Washington, southeast of St. George, and in Dameron Valley.

Trilinear plots of common ion analysis of water samples collected resulted in the designation of three types of water. In general, type I waters, ( $\mathrm{Ca}-\mathrm{Na} \mathrm{HCO}_{3}-\mathrm{Cl}-\mathrm{SO}_{4}$ ) are from aquifers in the Navajo Sandstone and basalt in the northeastern part of the basin, in Snow Canyon, in the Pine Valley Mountains, and near Anderson Junction. Most type II waters ( $\mathrm{Ca}-\mathrm{Na} \mathrm{Cl}-\mathrm{SO}_{4}-\mathrm{HCO}_{3}$ ) are from shallow alluvial aquifers in the Santa Clara and St. George areas, in addition to water from the Moenkopi Formation in Washington Fields. Type Ill water $\left(\mathrm{Na}-\mathrm{Ca} \mathrm{Cl}-\mathrm{SO}_{4}-\mathrm{HCO}_{3}\right.$ is from the Navajo Sandstone aquifer north of St. George and Washington. Total dissolved solids values in tested water range from $103 \mathrm{ppm}((\mathrm{mg} / \mathrm{l})$ in the recharge area to 9,523 ppm (mg/l) at Pah Tempe Hot Springs. Less than one-third of the samples collected are slightly saline and thirteen samples are moderately saline.
\end{abstract}

In most instances the $\mathrm{Na}-\mathrm{K}-\mathrm{Ca}$ and chalcedony geothermometers are the appropriate ones to employ in temperature calculations. The majority of the $\mathrm{Na}-\mathrm{K}-\mathrm{Ca}$ calculated reservoir temperatures range between $30^{\circ}$ and $50^{\circ} \mathrm{C}$. Anomalous geothermometer temperatures were calculated for water from Pah Tempe and a number of locations in St. George and vicinity.

Temperature-depth measurements were made in 17 shallow water wells and in one deep geothermal exploration well. Most gradients calculated are from $0.98^{\circ}$ to $1.3^{\circ} \mathrm{F} / 100$ feet $\left(18^{\circ}\right.$ $24^{\circ} \mathrm{C} / \mathrm{km}$ ) although one well is considerably higher with a gradient of $1.85^{\circ} \mathrm{F} / 100$ feet $\left(33.7^{\circ} \mathrm{C} / \mathrm{km}\right)$.

In addition to the known thermal areas of $\mathrm{Pah}$ Tempe and Veyo Hot Spring, an area north of Washington and St. George is delineated in this study to have possible low-temperature geothermal potential. This area is distinguished on the basis of both anomalous surface and calculated geothermometer temperatures. Further work is needed, however, to define the resource.

\section{INTRODUCTION}

The low-temperature geothermal assessment of the Santa Clara and Virgin River Valleys and surrounding terrain was funded jointly by the U.S. Department of Energy (grant no. DE-FG07-84ID12543) and the Utah Geological and Mineral Survey. The boundaries of the study area are taken from the Geothermal Resources of Utah map (Murphy, 1980) which designates the area as being favorable for discovery and development of local sources of low-temperature (less than $90^{\circ} \mathrm{C}$ ) water.

The geothermal study encompasses an area of approximately 250 square miles $\left(650 \mathrm{~km}^{2}\right)$ in south-central Washington County in southwestern Utah (figure 1). St. George, population 25,000 (1986), is the largest city in the area, 


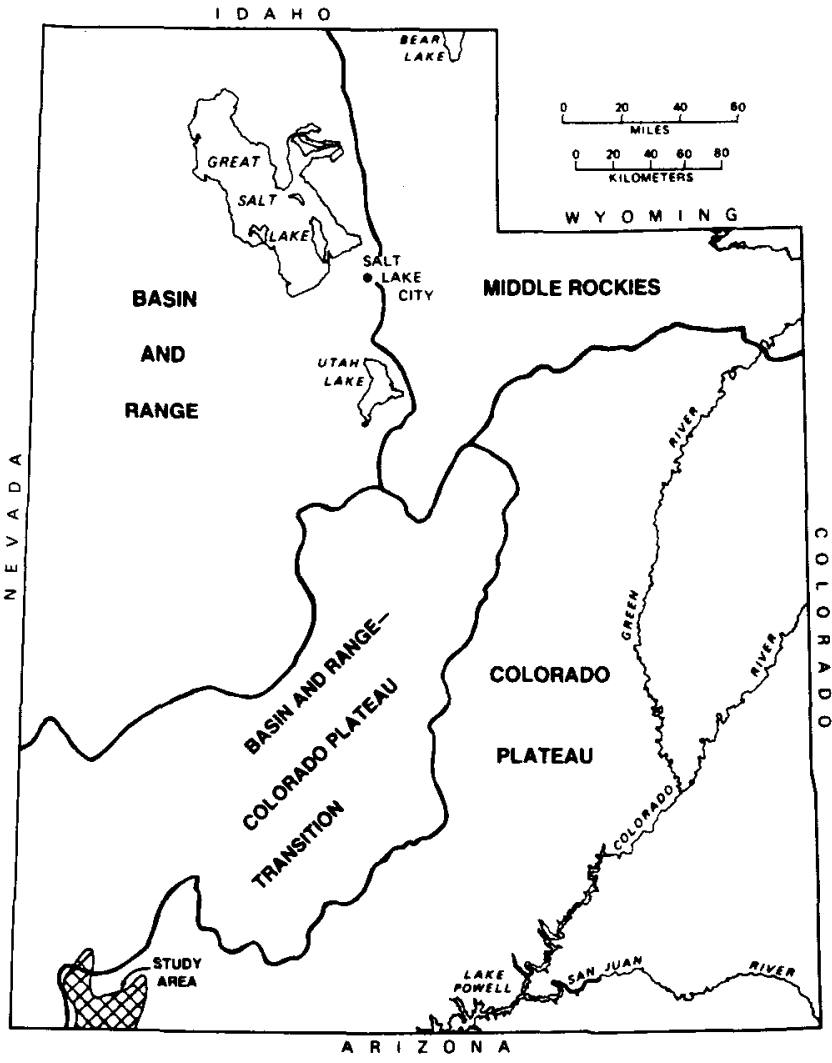

Figure 1. Index map showing the geothermal study area and physiographic provinces.

growing at an annual rate of 12 percent. The metropolitan area of St. George, Bloomington, Santa Clara, and Washington has a combined population of 35,000 . Smaller cities include Veyo and Central in the northwest corner of the study area and Hurricane, La Verkin, and Toquerville northeast of St. George.

The geothermal assessment is primarily based on the following:1) a temperature survey of springs, 2) chemical analyses and calculated geothermometer temperatures of water samples collected from selected springs and wells, 3) chemical analyses and calculated geothermometer temperatures of spring and well water samples in the literature, 4) thermal gradients measured in accessible wells, and 5) geology.

\section{PHYSIOGRAPHIC AND GEOLOGIC SETTING}

The majority of the study area lies in the Colorado Plateau physiographic province, immediately south of the Basin and Range-Colorado Plateau transition zone (figure 1). The study area approximately coincides with the boundary for the St. George basin subprovince of Stokes (1977) and in this report will be referred to as the St. George basin. The basin is bordered by the Pine Valley Mountains to the north, the Beaver Dam Mountains to the west, the Hurricane Cliffs to the east, and the Arizona state line to the south. The Virgin River is the largest river in the basin and drains the eastern portion of the area. It enters the study area just south of La Verkin and flows into Arizona southwest of Bloomington. The Santa Clara River has its headwaters in the Pine Valley Mountains and drains the western half of the study area. The confluence of the Santa Clara with the Virgin River is about two miles (3 $\mathrm{km}$ ) south of St. George.

A structural transition exists within Washington County with flat-lying sedimentary strata, typical of the Colorado Plateau, on the east, and fault blocks of previously folded and thrust-faulted rocks typical of the Basin and Range Province on the west. The St. George basin, although part of the Colorado Plateau, is a transition block with sedimentary rocks moderately folded along northeast axes (Cook, 1960) and is more typical of the Basin and Range-ColoradoPlateau transition zone. The block, bordered on the east by the Hurricane fault and on the west by the Grand Wash fault, has a very gentle regional dip to the northeast (Peterson, 1983).

A sequence of sedimentary rocks over 19,000 feet $(5,800 \mathrm{~m})$ thick lies between the Precambrian metamorphic rocks in the Beaver Dam Mountains west of the St. George basin and the Tertiary igneous rocks of the Pine Valley and Bull Valley Mountains north and northwest of the basin (Cook, 1960). Paleozoic sedimentary rocks include the Permian Kaibab Limestone, which is exposed along the crest of the Virgin anticline and with the Permian Toroweap Limestone in the Virgin River gorge west of Hurricane. Descriptions of all the formations are given in the description of map units accompanying plate 1 .

Most of the basin is characterized by Mesozoic strata, which include the Triassic Moenkopi, Shinarump, Chinle, Moenave, and Kayenta Formations; the Jurassic Navajo, Carmel, and Entrada Formations; and Cretaceous rocks which include the Dakota, Tropic, Straight Cliffs, Wahweap, and Kaiparowits Formations (Cook, 1960; Hamblin, in press a and b). Sedimentation during the Triassic and Jurassic periods took place during three phases:1) deposition of fine, largely terrestrial sediments throughout the Triassic, 2) deposition of continental sandstone in Early Jurassic, and 3) shallow marine sedimentation in Late Jurassic.

The Moenkopi Formation and the Navajo Sandstone are the predominant sedimentary units outcropping in the St. George basin. The Moenkopi Formation outcrops south of the Santa Clara River, along the Virgin anticline, and on the east side of the Washington fault. The Navajo Sandstone forms the massive cliffs west of Leeds and north of St. George and is also present in the Sand Mountain area in the southeast portion of the basin. The formation is an important aquifer.

The Tertiary Claron Formation is only present in the northwest corner of the study area; however, it is found along the base of the Pine Valley Mountains where it has been intruded by a laccolith. Cook (1960) refers to this Tertiary quartz monzonite porphyry as among the largest known laccoliths. The Pine Valley laccolith has not been dated; however, the three intrusions, perhaps laccoliths, of the Iron Springs district, approximately 12.5 miles $(20 \mathrm{~km}$ ) west of 
Cedar City, are of Miocene age. The Three Peaks, Granite Mountain, and Iron Mountain porphyritic quartz monzonite plutons are about 20 m.y. to 21 m.y. old based partly on $\mathrm{K}-\mathrm{Ar}$ ages of intrusive rocks (Armstrong, 1970) and largely on field relations between the plutons and dated volcanic rocks (Rowley and Barker, 1978). The nearby quartz monzonite Pine Valley laccolith may be the same age as the plutons in the Iron Springs district.

A late Cenozoic hornblende dacite outcrops approximately one mile $(2 \mathrm{~km})$ northeast of the town of Central. It flowed down an ancient valley to the south of Eight Mile Spring. The dacite is composed of a lower, glassy, cliff-forming unit about 50 to 100 feet $(15-30 \mathrm{~m})$ thick and an upper, denser porphyritic dacite at least 200 feet $(60 \mathrm{~m})$ thick (Cook, 1960). The gray, porphyritic dacite has phenocrysts of hornblende, biotite, plagioclase, and sanidine. As part of this study, a potassiumargon age determination was done on the biotite concentration and an age of $3.1 \pm 0.2 \mathrm{~m} . \mathrm{y}$. was determined:

Hornblende dacite (C-39-16) ldbb; Washington County, Utah

Analytical data: $\mathrm{K}_{2} \mathrm{O}=7.77 \% ;{ }^{40} \mathrm{Ar}=3.49 \times 10^{-11} \mathrm{~mol} / \mathrm{g}$; ${ }^{40} \mathrm{Ar} / \Sigma{ }^{\circ 0} \mathrm{Ar}=0.134$

$\mathrm{K}-\mathrm{Ar}$ (biotite) $3.1 \pm 0.2$. m.y.

(note: ${ }^{40} \mathrm{Ar}$ refers to radiogenic ${ }^{40} \mathrm{Ar}$ )

Late Cenozoic basaltic flows and cinder cones in the St. George basin provide important data on the tectonic and geomorphic history of the area. Volcanic centers were primarily near the Pine Valley Mountains and the flows traveled southward along stream valleys. After the basalt solidified, the stream channels moved laterally into the lessresistant sedimentary rock and cut new channels. The erosionresistant basalt flows now cap long, narrow, sinuous ridges called inverted valleys. This process repeated itself with successively younger flows, and the relative ages of the flows can be determined from their height above the present drainage, the older flows lying above the younger basalt. Displacement of the flows by faulting provides time constraints for the periods of recurrent movement along major faults (Hamblin, 1963).

Four stages of basalt flows have been distinguished in the St. George basin on the basis of geomorphic relationships and age determinations (Hamblin, 1970a). The oldest flows (Tb on plate 1) have been classified as Stage I and are those deposited on an erosional surface that is not related to the present drainage system. These basalts are more than $2 \mathrm{~m}$.y. old. Only minor flows of these basalts over $2 \mathrm{~m}$.y. old occur in the basin. Stage I flows on the Shivwits Plateau, south of the St. George basin in Arizona, have been dated at $6 \mathrm{~m}$.y. (Hamblin, 1970b). Stage I flows represent a long time period with intermittent eruption of basalt. Stage II flows (QTb on plate 1) were deposited on an erosional surface which is now 200 to 500 feet $(60-150 \mathrm{~m})$ above the present drainage. These flows are approximately $1 \mathrm{~m}$.y. to $2 \mathrm{~m}$.y. old and present throughout the basin. Erosional remnants are usually elongate and parallel to the present drainge as inverted valleys. $K-A r$ dates for two St. George flows range from $2.24 \pm 0.11 \mathrm{~m}$.y. (highest flow) to 1.07 $\pm 0.04 \mathrm{~m}$.y. (lower flow) (Hamblin and others, 1981). Stage III flows ( $\mathrm{Qb}_{1}$ on plate 1) are those that were deposited on a surface that is 20 to 100 feet $(6-30 \mathrm{~m})$ above the present drainage. Incipient inverted valleys are developed on these flows, and the sources and cinder cones associated with the eruptions are preserved. These flows are near Veyo, Central, and Hurricane. Stage III flows are approximately between 1,000 years and $0.25 \mathrm{~m}$.y. old. A flow near Hurricane has an age of $0.293 \pm 0.087 \mathrm{~m}$.y. (Hamblin and others, 1981). Stage IV flows ( $Q b_{2}$ on plate 1) have been deposited on the present erosional surface. Cinder cones are well preserved and most flows are traceable to their source. These basalts, present north of Santa Clara in Snow Canyon, are less than 1,000 years old. Flows in the San Francisco Mountains area near Flagstaff, Arizona, with similar preservation of original flow structures, are dated at 900 years old (Hamblin, in press b).

The St. George basin contains varied types of late Cenozoic lavas (Best and Brimhall, 1970). Basalts are undersaturated in silica (Yoder and Tilley, 1962) and within the alkalic basalt field on the alkalies-silica plot (Macdonald and Katsura, 1964). In the St. George basin the majority of the basalt flows are quartz-bearing basaltic andesite and hawaiite. The basaltic andesite occurs in Stage II and IIl flows (QTb and $\mathrm{Qb}_{1}$ on plate 1) in the northeast portion of the basin and near St. George. These lavas are characterized by sparse phenocrysts of olivine and large, cognate crystals of quartz and plagioclase. The hawaiite is found as Stage II and III flows in the eastern part of the basin and as Stage IV flows ( $\mathrm{Qb}_{2}$ on plate 1) north of Santa Clara. The matrix is medium gray and some basalts are aphyric, although olivine phenocrysts are usually present and bytownite and augite appear in many flows (Best and Brimhall, 1974). There are two groups of unconsolidated Quaternary sediments in the area. Older sediments are, largely, coarse gravels that mantle the pediment. These poorly sorted gravels were probably deposited by torrents and mudflows during the Pleistocene (Proctor, 1953). The younger sediments form narrow valleys as well as local deposits of landslide, hillwash, and dune material (Cook, 1960).

\section{STRUCTURAL SETTING}

Two structural trends are present in Washington County. Laramide-age structures are seen by northeasterly aligned folds and faults. The second set of structures formed during the Tertiary primarily as north-south-striking faults. Late Cenozoic movements have been influenced by both structural trends. The geologic map presents the major structural features of the St. George basin, including: 1) Virgin anticline, 2) Hurricane fault, 3) Grand Wash fault, and 4) Washington fault (plate 1).

The Virgin anticline cuts the St. George basin in a northeasterly direction for about 16.5 miles $(27 \mathrm{~km})$. The feature is a broad, symmetrical fold with maximum flank dips ranging from $25^{\circ}$ to $30^{\circ}$. The anticline formed as a result of compression late in the Laramide orogeny, probably in Eocene time (Hamblin personal communication, 1986). The oldest formation exposed along the axis of the anticline is the Permian Kaibab Limestone (Cook, 1960). 
Extension and faulting associated with post-Laramide tectonics in early to middle Miocene time produced the northtrending Hurricane, Grand Wash, and Washington faults. The age of initial movement on these faults may be related to relative down-dropping of the eastern Basin and Range Province as a result of collapse of regional upwarping during late Tertiary time (Best and Hamblin, 1978; Earth Sciences Associates, 1982). The upthrown block is to the east on these normal faults.

The Hurricane fault is a major structural feature extending over 186 miles $(300 \mathrm{~km})$ from Cedar City, Utah southward into Arizona. It is marked by the west-facing escarpment named the Hurricane Cliffs on the east side of the St. George basin. Approximate displacement on the fault increases northward from 5900 feet $(1,800 \mathrm{~m})$ at the state line to 7900 feet $(2,400 \mathrm{~m})$ near the town of Hurricane, and a possible 9850 feet $(3,000 \mathrm{~m})$ north of Hurricane. The fault is composed of several fault planes in a zone of displacement with a maximum width of one mile $(1.6 \mathrm{~km})$ (Hamblin, 1970b). Reverse drag has been formed repeatedly during recurrent movement along the fault (Hamblin, 1965). Eight basalt flows ranging in age from 18 m.y. to a few thousand years erupted across the fault and have been subsequently displaced. Hamblin estimates that the recurrence interval for the Hurricane fault during the last 10 to $15 \mathrm{~m}$.y. is $0.25 \mathrm{~m}$.y. (personal communication, 1986). Based on offset of dated basalt flows, 200 feet $(600 \mathrm{~m})$ of movement on the fault has occurred during the last one m.y. Current displacements are judged to be on the order of 1000 to 1650 feet per m.y. (300-500 m/m.y. or 0.03-0.05 cm/yr). Quaternary movement is evidenced by displaced late Pleistocene alluvium (Earth Sciences Associates, 1982).

The Grand Wash fault, also known as the Gunlock/Cedar Pocket Canyon/Veyo fault, can be traced from Gunlock, on the west side of the St. George basin, into northwestern Arizona, a distance of approximately 100 miles $(159 \mathrm{~km})$. The structural block between this fault and the Hurricane fault has been uplifted at least 210 feet $/ \mathrm{m} . y$. ( $64 \mathrm{~m} / \mathrm{m}$.y.) in late Cenozoic time (Hamblin and others, 1981). Displacement along the Grand Wash fault zone decreases northward. Offset that may be 3 miles $(4,880 \mathrm{~m})$ near the mouth of the Grand Canyon, Arizona decreases to less than 1500 feet $(460 \mathrm{~m})$ at the state line and to less than 300 feet $(90 \mathrm{~m})$ in Utah. Based on the amount of erosion on the Grand Wash Cliffs in Arizona, the main movement of the fault occurred in early Miocene to late Pliocene time. Stage I basalt flows about 6 m.y. old, approximately 34 miles $(55 \mathrm{~km})$ south of Utah, have been displaced by the fault, which indicates recurrent movement in that area (Hamblin, 1970b).

The Washington fault is a small-scale version of the Hurricane and Grand Wash faults. The St. George basin is nearly bisected by the Washington fault, which extends southward from the foothills of the Pine Valley Mountains across the Virgin anticline and into Arizona over a distance of about 36 miles $(58 \mathrm{~km})$. The fault system follows a conjugate fracture system trending $\mathrm{N} 26^{\circ} \mathrm{E}$ and $\mathrm{N} 16^{\circ} \mathrm{W}$. Similarities in fault patterns between this system and the Hurricane fault suggest origins with similiar stress fields on rocks of closely related composition (Petersen, 1983). Displacement on the Washington fault increases southward. Offset has been estimated at less than 1,000 feet near the Virgin River where the fault breaches the Virgin anticline, increasing to $2495(760 \mathrm{~m})$ at the Arizona border (Dobbin, 1939). Stage I basalt flows dated at 2.9 m.y. (Best and Hamblin, 1978) are offset by 197 feet $(60 \mathrm{~m})$ where they cross the fault indicating an average fault displacement of about 69 feet $/ \mathrm{m} . y .(21 \mathrm{~m} / \mathrm{m} . \mathrm{y}$.) Drag features, thought to be the result of fault movement, are seen on 2.3 m.y.-old Stage I basalts and suggest recurrent movement during this time span. Woodward and Clyde have found displaced Quaternary alluvial sediment along the Washington fault (Petersen, 1983). Late Quaternary movement along the Washington fault has been documented by Earth Sciences Associates (1982) who believe that fault-related displacements of alluvial materials, seen in exploratory trenches, are likely to have occurred during Holocene time.

\section{SEISMICITY}

The Hurricane, Grand Wash, and Washington faults are considered to be seismically active (Earth Sciences Associates, 1982). All three fault zones lie within the Intermountain seismic belt - a major zone of intraplate seismicity in western North America. Two earthquakes of about 5 to 5.5 magnitude and several earthquake swarms have occurred in historic time on the Hurricane fault zone in the Cedar City area. An earthquake of magnitude 5.0 (estimated) that may have been associated with the Washington fault occurred near St. George in 1891. Two other earthquakes of magnitudes 5.0 and 6.3 occurred in 1902 near Pine Valley about 22 miles $(35 \mathrm{~km})$ north of St. George (Arabasz and others, 1979; Christensen and Deen, 1983).

\section{HEAT FLOW}

Heat flow is the conductive transfer of heat from the earth's interior and, therconditions at depth. Heat flow data within the study area are sparse. The only two measurements are 98 $\mathrm{mW} / \mathrm{m}^{2}$ (milliwatts per square meter) or $2.3 \mathrm{HFU}$ (heat flow units) near Central on the western edge of the Pine Valley intrusion, and $74 \mathrm{~mW} / \mathrm{m}^{2}$ (1.8 HFU) in Snow Canyon State Park, 7.5 miles $(12 \mathrm{~km})$ northwest of St. George (Chapman and others, 1978). Figure 2 illustrates heat flow for the entire state (Lachenbruch and Sass, 1980). Representative heat flow for the Utah portion of the Basin and Range Province is $90 \pm$ $10 \mathrm{~mW} / \mathrm{m}^{2}$ (2.2 HFU), significantly above the continental average. Heat flow in the Colorado Plateau is near the average at $49 \pm 8 \mathrm{~mW} / \mathrm{m}^{2}(1.2 \mathrm{HFU})$ (Chapman and others, 1978). The high heat flow in regions of extensional tectonics, like the Basin and Range Province, is caused by lithosphere extension and magmatism (Lachenbruch and Sass, 1978). Even though the study area is within the Colorado Plateau, it exhibits heat flow values similar to those measured in the Basin and Range.

\section{HYDROLOGIC SETTING}

The central Virgin River basin covers about 1000 square miles $(2,590$ square $\mathrm{km})$ in Washington and Iron Counties 


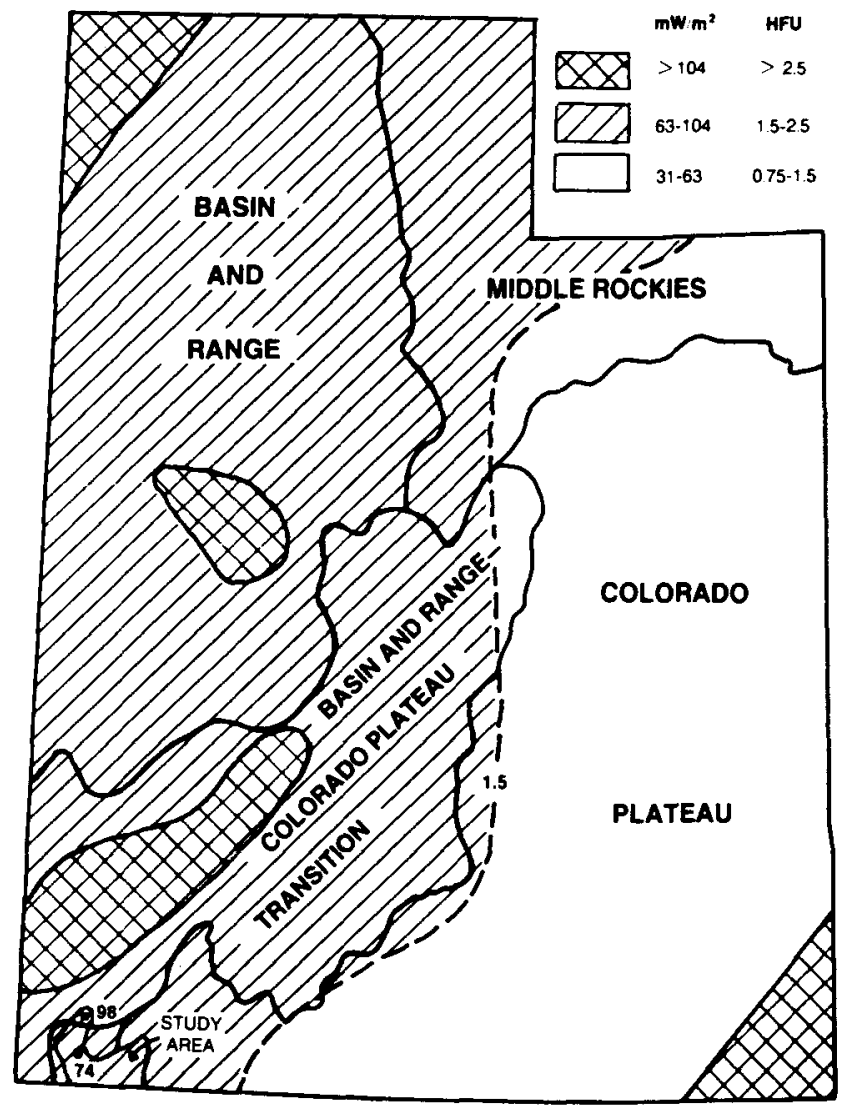

Figure 2. Heat flow map of Utah from Lachenbruch and Sass (1980) showing measurements taken in the George basin from Chapman and others (1978).

This basin includes the study area and additional ground north along the Hurricane fault to Kanarraville, west from there including the Pine Valley and Bull Valley Mountains, and south from there along the crest of the Bull Valley and Beaver Dam Mountains. As the name implies, the area is drained by the Virgin River and its tributaries, part of the Colorado River system. The major tributary within the study area is the Santa Clara River. The Virgin River is perennial and its tributaries are perennial, intermittent, or ephemeral (Cordova and others, 1972).

\section{PRINCIPAL AQUIFERS}

Aquifers are present in both unconsolidated and consolidated rocks in the St. George basin. About 25 percent of the basin is covered by unconsolidated alluvial sands and gravels which supply about 80 percent of the water discharged by relatively shallow water wells. Half of the water samples collected for the geothermal assessment were from aquifers in unconsolidated rocks. The thickness of the saturated zone in these aquifers varies but generally is less than 100 feet $(30 \mathrm{~m})$; depth to the saturated zone ranges from 10 to 85 feet $(3-25 \mathrm{~m})$. Average yield of these wells is less than $250 \mathrm{gpm}(16 \mathrm{l} / \mathrm{s})$.

The Moenkopi, Chinle, Moenave, and Kayenta Formations, the Navajo Sandstone, and the Tertiary and Quaternary basalts supply most of the springs in the basin discharging from the consolidated-rock aquifers (generally yielding less than $50 \mathrm{gpm}$ or $3 \mathrm{l} / \mathrm{s}$ ). Although many wells tap consolidatedrock aquifers, the yield is so low that only about 20 percent of the water withdrawn by wells in the basin comes from consolidated rocks. Water samples in the basin were collected from the Moenkopi, Shinarump, Kayenta Formations, the Navajo Sandstone, the Cretaceous unit, and the basalts. Yield from the aquifers in these units is small to moderate ( 9.5 to 100 gpm or $0.6-6.3 \mathrm{l} / \mathrm{s}$ ), with the exception of the Navajo Sandstone and basalt where the flow is moderate to very large (100 to more than $1000 \mathrm{gpm}, 6.3-63 \mathrm{l} / \mathrm{s}$ ). This higher yield is due to the larger, more extensive fractures in the hard, brittle rock and, locally, the Navajo Sandstone may contain a significant amount of intergranular openings (Cordova and others, 1972).

\section{RECHARGE, MOVEMENT, AND DISCHARGE}

Recharge to the ground-water reservoir in the central Virgin River basin is from the following three sources: 1) infiltration of precipitation primarily in winter $-70,000$ acre feet $(8,640$ $\mathrm{km}^{3}$ ) annually; 2) infiltration of stream flow directly from water-ways or irrigated land - 15,000 acre feet $\left(1,850 \mathrm{~km}^{3}\right)$ annually; 3) subsurface inflow in the upper 500 feet $(150 \mathrm{~m})$ of saturated rock from east of the Hurricane Cliffs and from Arizona $-20,000$ acre feet $\left(2,470 \mathrm{~km}^{3}\right.$ ) annually (Cordova and others, 1972).

The direction of ground-water movement in the St. George basin is toward the Virgin River and its tributaries. Arizona provides flow from east of the Hurricane Cliffs and gains water from beneath and west of the Virgin River valley.

Discharge of ground water in the central Virgin River basin is estimated for 1970 as: 1) seepage into streams $-24,000$ acre feet $\left.\left(2,960 \mathrm{~km}^{3}\right) ; 2\right)$ spring and drain discharge from consolidated rocks - 40,000 acre feet $\left(4,930 \mathrm{~km}^{3}\right)$; 3) evapotranspiration by phreatophytes, mainly in and next to the channels of the Santa Clara and Virgin Rivers - 13,000 acre feet $\left.\left(1,600 \mathrm{~km}^{3}\right) ; 4\right)$ discharge by wells largely from the Santa Clara River valley and Fort Pierce Wash in the St. George basin -9,100 acre feet $\left(1,120 \mathrm{~km}^{3}\right)$; and 5) subsurface outflow in the upper 500 feet $(150 \mathrm{~m})$ of saturated rock most likely at the Arizona border west of the Virgin River - 2,000 acre feet $\left(250 \mathrm{~km}^{3}\right)$ (Cordova and others, 1972).

\section{KNOWN GEOTHERMAL AREAS}

\section{PAH TEMPE HOT SPRINGS}

Pah Tempe Hot Springs, also known as La Verkin and Dixie Hot Springs, is the highest-temperature thermal area within the basin. The springs are located in the Virgin River gorge on the east side of Utah State 17 between Hurricane and La Verkin (plate 1). The springs issue from fractures in the Permian Toroweap Limestone at the base of the cliff and also from the channel of the Virgin River. The majority of the cliffs forming the Virgin River gorge are composed of the overlying Permian Kaibab Limestone. The north-trending Hurricane 
fault passes just to the west of the springs, but the springs lie within the fault zone. The hot springs are located within 650 feet $(200 \mathrm{~m}$ ) of 1 to $2 \mathrm{~m}$.y.-old basalts (QTb plate 1) and are approximately one-half mile $(1 \mathrm{~km})$ from basalt flows that outcrop widely in the vicinity of Hurricane ranging from 1,000 years to $0.25 \mathrm{~m} . \mathrm{y}$. old ( $\mathrm{Qb}$ plate 1).

The recorded temperatures of the hot springs have varied with time from $38^{\circ}$ to $56^{\circ} \mathrm{C}$ (Mundorff, 1970). Measured temperatures between 1960 and 1966 ranged from $38^{\circ}$ to $42^{\circ} \mathrm{C}$; however, much warmer temperatures of $42^{\circ}$ to $56^{\circ} \mathrm{C}$ (Crook, 1899; Peale, 1886) were reported in the 1800s. It is not known if the original temperature measurements were inaccurate or if the springs have cooled significantly over the past 80 years. A temperature of $42^{\circ} \mathrm{C}$ was measured in February, 1986. The flow of the springs has also varied with time. Gregory (1950) reports a flow of about $1000 \mathrm{gpm}(63 \mathrm{l} / \mathrm{s})$, whereas Mundorff (1970) lists flow measurements taken by the U.S. Geological Survey and Utah State University from 1956 to 1966 to be between 4500 and $5200 \mathrm{gpm}(283-328 \mathrm{l} / \mathrm{s})$.

Pah Tempe springs have a very high TDS content. Calculated TDS values on five samples taken between 1940 and 1966 range from 9,390 to $9,760 \mathrm{ppm}(\mathrm{mg} / \mathrm{l})$. A slightly lower TDS of $7,214 \mathrm{ppm}(\mathrm{mg} / \mathrm{l})$ was found in the sample collected for this study. The source of these dissolved solids is not known (Mundorff, 1970), and the high TDS content of the springs has an adverse effect on the quality of water in the Virgin and Colorado Rivers. Water in the hot springs is probably of meteoric origin. Current development at Pah Tempe consists of a swimming pool and mineral bath spa.

\section{VEYO HOT SPRING}

Veyo Hot Spring is located southeast of the town of Veyo along the Santa Clara River which has incised 1 and $2 \mathrm{~m} . y$.-old basalt flows (QTb plate 1). The spring flows into the river at the base of these canyon walls. Holocene and Pleistocene basalt flows $\left(\mathrm{Qb}_{1}\right.$ plate 1) surround the hot spring area. The water is probably of meteoric origin. Mundorff (1970) reports temperatures of $32^{\circ}$ to $37^{\circ} \mathrm{C}$, calculated TDS of 389 to 402 ppm (mg/1), and a discharge of $120 \mathrm{gpm}(7.6 \mathrm{l} / \mathrm{s})$ in 1966 and 1967. A temperature of $29.5^{\circ} \mathrm{C}$ was measured in February 1986 , with a calculated TDS of $395 \mathrm{ppm}(\mathrm{mg} / \mathrm{l})$. The orifice of the spring has been covered by a swimming pool which is part of a resort open from the end of March through August.

\section{WASHINGTON HOT POT}

A warm spring located north of the city of Washington fills a circular depression about 30 feet $(9 \mathrm{~m})$ in diameter with a maximum depth of 5 feet $(1.5 \mathrm{~m})$. The hot pot is located in the Navajo Sandstone and is a little over one-half mile $(1 \mathrm{~km})$ west of the Washington fault. No information on this spring could be found in the literature. A temperature of $24.5^{\circ} \mathrm{C}$ was measured in February, 1986 with a calculated TDS of 311 ppm (mg/l).

\section{TEMPERATURE SURVEY}

Geothermal resources that are below $90^{\circ}$ are designated as low temperature. The minimum temperature for a low- temperature geothermal resource has been defined to be $10^{\circ}$ above the mean annual air temperature at the surface and should increase by $1.37^{\circ} \mathrm{F} / 100$ feet $\left(25^{\circ} / \mathrm{km}\right)$ with depth (Reed, 1983). The State Climatologist's office in Logan reports the mean temperature in St. George to be $16.6^{\circ}$. In this study, $26^{\circ} \mathrm{C}$ or warmer water was considered to have low-temperature geothermal potential; water between $20^{\circ}$ and $25.9^{\circ} \mathrm{C}$ may have geothermal potential. The $20^{\circ}$ minimum for thermal water has been used in previous studies (Bliss, 1983; Mundorff, 1970).

An attempt was made to locate all springs in the basin that are shown on the USGS $30 \times 60$ minute St. George quadrangle; however, some springs were not found and others were not flowing. Figure 3 shows the spring and well temperatures that were measured as part of this study, in addition to 22 well and spring temperatures compiled from the literature. The published data were selected because their complete chemical analyses were used in the trilinear diagrams and geothermometer temperature calculations discussed in a later section. Temperatures were measured using a Yellow Springs Instrument (YSI) Model 33 Temperature-Conductivity Meter.

Spring and well temperatures range from a low of $7^{\circ} \mathrm{C}$ in recharge areas in the Pine Valley and Bull Valley Mountains to a high of $42^{\circ} \mathrm{C}$ at Pah Tempe Hot Springs. Spring temperatures of $20^{\circ}$ or higher were found at Pah Tempe Hot Springs $\left(42^{\circ} \mathrm{C}\right)$, Veyo Hot Spring $\left(29.5^{\circ} \mathrm{C}\right)$, and Washington hot pot $\left(24.5^{\circ} \mathrm{C}\right)$ as already discussed. Additional thermal water in the basin is evident at Green Spring, about threefourths mile $(1.2 \mathrm{~km})$ west of the Washington hot pot, where a temperature of $23^{\circ} \mathrm{C}$ was measured (figure 3). Two springs with water temperatures of $20^{\circ} \mathrm{C}$ are listed in the literature and include West St. George Springs, located near the northwest edge of the city, and an unnamed spring just northwest of Interstate 15 between Washington and Middleton. A temperature of $11.5^{\circ} \mathrm{C}$, however, was measured for the West St. George Spring in February, 1986. Washington City Spring, approximately one-half mile $(1 \mathrm{~km})$ east of the hot pot, was $19.5^{\circ} \mathrm{C}$ and a large number of other springs in the basin have water temperatures of $19^{\circ} \mathrm{C}$.

Some wells in the basin have water temperatures between $20^{\circ}$ and $21.5^{\circ} \mathrm{C}$, fewer are between $24.5^{\circ}$ and $29^{\circ} \mathrm{C}$, and one well measured $40^{\circ} \mathrm{C}$. The well temperatures are discussed from northwest to northeast across the basin (figure 3). A temperature of $26.5^{\circ} \mathrm{C}$ (W16) was measured at Dameron Valley and reportedly the well pipe is warm to the touch during the winter. The St. George City wells in Snow Canyon (W12, W17, W69) range from $18^{\circ}$ to $20^{\circ} \mathrm{C}$. Sample W31, west of Ivins, measured $20^{\circ} \mathrm{C}$, but the well stopped flowing after 15 minutes when the temperature was taken. Water from St. George City Creek Wells no. 1 and 2(W36, W74, W75), north of St. George, measured $26^{\circ} \mathrm{C}$. The warmest well water found in the basin was north of these wells along Middleton Wash where sample W68 measured $40^{\circ} \mathrm{C}$. This well was drilled by Terracor for culinary water but was abandoned because of temperature and high TDS. Washington City well (W76), located north of Green Spring and the hot pot, was $29^{\circ} \mathrm{C}$. A 
temperature of $24.5^{\circ} \mathrm{C}$ was measured southeast of St. George (W49), and southeast of that in Washington Fields two samples (W33 and $\mathrm{W} 41)$ are $21^{\circ}$ and $21.5^{\circ} \mathrm{C}$, respectively. South of Berry Springs, two samples (W22 and W23) from Stratton Turf Farm measure $21^{\circ}$ and $20^{\circ} \mathrm{C}$. Approximately $2-1 / 2$ miles $(4 \mathrm{~km})$ to the east, sample $W 70$ is $21.5^{\circ} \mathrm{C}$ and sample W 35 is $20^{\circ} \mathrm{C}$. Sample W35 is from a well drilled by Floratec. Three exploratory wells were drilled at this location in an attempt to establish a geothermally-heated greenhouse operation; drilling did not encounter water of the required temperature. An artesian well approximately $3.5 \mathrm{~km}$ southeast of Leeds (W61) has a water temperature of $21.5^{\circ} \mathrm{C}$.

\section{WATER CHEMISTRY}

Fifty-five spring and well samples were collected as part of this study and 22 samples taken from the literature (figure 4). A Corning-Orion Model $407 \mathrm{~A} / \mathrm{F}$ specific ion meter with an Orion gel-filled Model 91-05 combination $\mathrm{pH}$ electrode was used to measure $\mathrm{pH}$. Three readings were taken and averaged. A YSI Model 33 Temperature-Conductivity Meter was used to measure conductivity. The water samples were analyzed at the Earth Science Laboratory of the University of Utah Research Institute (ESL/UURI) and results are presented in table 1.

Sample collection involved filtering the water through a GeoFilter Peristaltic Pump - Model \#004 using a 0.45 micron filter paper to fill two $500 \mathrm{ml}$ and one $32 \mathrm{ml}$ polyethylene bottles at each site. The $32 \mathrm{ml}$ bottle was acidified with reagent grade $\mathrm{HNO}_{3}$ to a final concentration of 20 percent $\mathrm{HNO}_{3}$ and analyzed for most of the elements and compounds in table 1 by an APL Inductivity Coupled Plasma Quantometer (ICPQ). One $570 \mathrm{ml}$ bottle was acidified with concentrated $\mathrm{HCl}$ to a final concentration of one percent $\mathrm{HCl}$ and analyzed for $\mathrm{SO}_{4}$. The water in the remaining bottle was not acidified and analyzed for $\mathrm{Cl}, \mathrm{F}, \mathrm{HCO}_{3}, \mathrm{CO}_{3}$, and TDS.

\section{COMMON ION ANALYSES}

The chemical analyses were entered into the elemental analyses program ELE at the ESL/UURI that generates trilinear diagrams and calculates geothermometers (Withrow, 1983). Common ion analyses, in percent of total milliequivalents per liter, are plotted on trilinear diagrams in figures 5 through 10 . The nomenclature to describe water samples is from Back (1961) and is presented on figure 4. The delineation of type I, Ia, II, IIa, and III waters is arbitrary and was done to aid the discussion of the water chemistry. Samples W43 and W24 are not shown because the percent of error in common ion balance was greater than 3 percent.

A spring sample was collected for chemical analysis if the water temperature was $20^{\circ} \mathrm{C}$ or greater. In addition, samples were taken in the Pine Valley Mountains and west of the basin in order to characterize recharge areas. An attempt was made to sample wells that were geographically representative of the basin; however, collection was largely controlled by the presence of water wells, their sampling access, and pumping schedule.

The samples are plotted on six trilinear diagrams grouped on the basis of geography and drainage basins. These groups are indicated on figure 3. Water from the northwest portion of the basin is shown on figure 5 . Samples include those taken northwest and southeast of the Santa Clara River and those west of the river, just west of the study area. Sample S6 (Pahcoon Spring) is from a recharge area. Veyo Hot Spring samples are $\mathrm{S} 2$ and $\mathrm{S} 56$. All the samples in figure 5 are $\mathrm{Ca}-\mathrm{Na}$ $\mathrm{HCO}_{3}-\mathrm{Cl}-\mathrm{SO}_{4}$ water (type I). The $\mathrm{pH}$ varies slightly between 7.3 and 7.7, with the exception of W27 near Gunlock Reservoir with $\mathrm{pH}$ 8.0. The well samples in the Veyo area were collected from wells drilled into basalt to depths of approximately 230 feet $(70 \mathrm{~m})$; the two wells south of Gunlock Reservoir were drilled into Navajo Sandstone about 560 feet $(170 \mathrm{~m})$.

Figure 6 represents those samples in the west-central part of the basin - northeast of the Santa Clara River, south of Red Mountains, and west of West Black Ridge. Well samples from Snow Canyon and Snow Spring are $\mathrm{Ca}-\mathrm{Na} \mathrm{HCO}_{3}-\mathrm{Cl}-\mathrm{SO}_{4}$ in character (type I) and slightly basic with a pH range of 7.8 - 8.3. The wells in Snow Canyon drilled in Navajo Sandstone are approximately 590 feet $(180 \mathrm{~m})$ deep, tapping an aquifer about 215 feet $(65 \mathrm{~m})$ below the surface. Water from the shallow wells south of Santa Clara and Miller Spring is $\mathrm{Ca}-\mathrm{Na} \mathrm{Cl-SO} 4-$ $\mathrm{HCO}_{3}$ in character (type II) with pH range of $7.2-7.9$. The water sampled in and near Ivins (W30, W31, W46) varies considerably. The Santa Clara and Ivins wells are shallow, about 130 feet $(40 \mathrm{~m})$ deep, and are located in alluvium. Aquifers are approximately 30 feet $(10 \mathrm{~m})$ below the surface.

Samples from the central part of the basin, the area northwest of the Virgin River and east of West Black Ridge, are plotted on figure 7 . This water is slightly basic with $\mathrm{pH}$ range 7.1 to 8.4 . Sample W49, southeast of Washington, is slightly acidic with a $\mathrm{pH}$ of 6.6. Samples S20 from Cougar Spring and S15 from Diamond Valley were collected in the Pine Valley Mountains, a recharge area. Along with the Washington hot pot and a well north of Washington, these four samples are $\mathrm{Ca}-\mathrm{Mg} \mathrm{HCO} 3-\mathrm{Cl}-\mathrm{SO}_{4}$ in character (type Ia). Well W21 is about 660 feet $(200 \mathrm{~m})$ deep and is completed in the Navajo Sandstone. The water table is 115 feet $(35 \mathrm{~m})$ below the surface. Type III group water is $\mathrm{Na}-\mathrm{Ca} \mathrm{Cl} \mathrm{SO}_{4} \mathrm{HCO}_{3}$ in character and was present in springs and wells north of $\mathrm{St}$. George and $W$ ashington. The wells are approximately 705 feet $(215 \mathrm{~m})$ deep and completed in the Navajo with the exception of well W53, 200 feet deep $(60 \mathrm{~m})$. Two aquifers are at depths of 280 feet $(85 \mathrm{~m})$ and 560 feet $(170 \mathrm{~m})$, respectively. Sample S1 from the St. George City aqueduct, originating south of Cougar Spring, is similar to type Ia water and was collected approximately 12.5 miles $(20 \mathrm{~km})$ south of Cougar Spring. Type $\mathrm{Il}$ water $\left(\mathrm{Ca}-\mathrm{Na} \mathrm{Cl}-\mathrm{SO}_{4}-\mathrm{HCO}_{3}\right)$ and type Ila water ( $\mathrm{Ca}-\mathrm{Na} \mathrm{Cl})$ were collected in and southeast of St. George along the Virgin River. Samples represent water from wells (about 65 to 250 feet, 20 - $75 \mathrm{~m}$ deep) completed in shallow aquifers.

The south-central portion of the basin (figure 8) is the area southwest of the Virgin River and west of Warner Ridge and Washington Dome; the latter feature is part of the Virgin anticline. The majority of these samples are $\mathrm{Ca}-\mathrm{Na} \mathrm{Cl}$ in character (type IIa) with $\mathrm{pH}$ between 7.0 and 7.8. All the water was collected from fairly shallow wells (less than 230 feet or 70 $m$ in depth) primarily drilled into the Moenkopi and tapping 


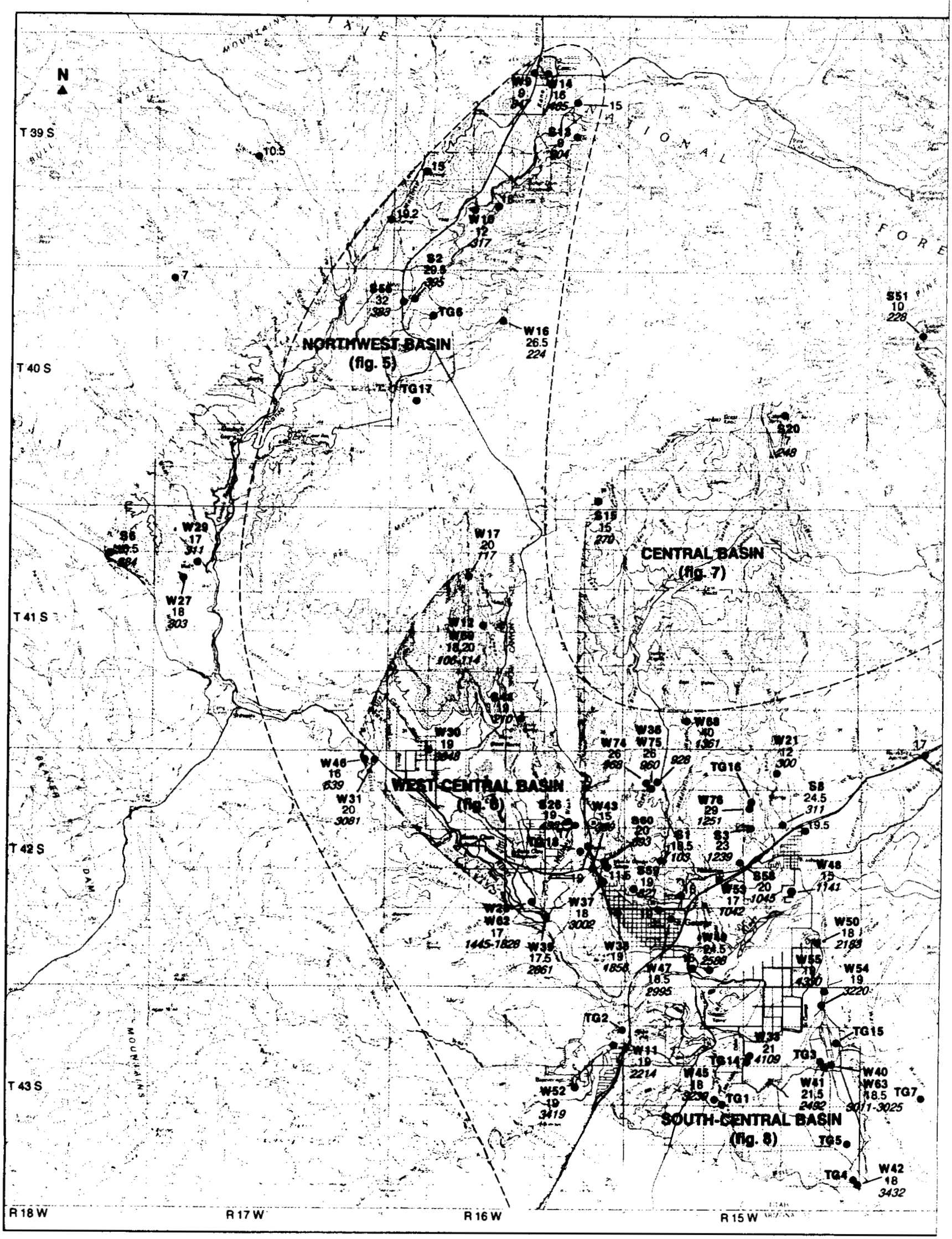




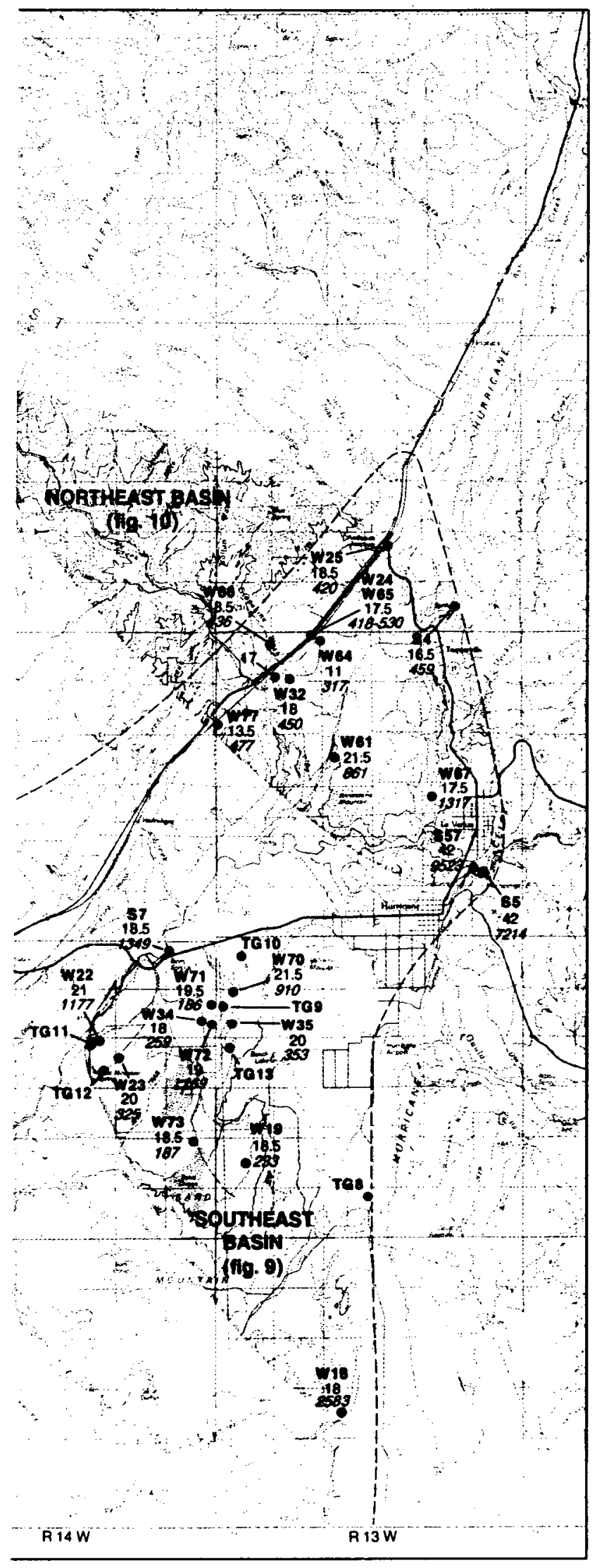

\section{EXPLANATION}

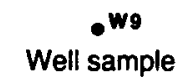

- 513

Spring sample

-TG6

Temperature-depth logging site

- 10.5

Water temperature, in ${ }^{\circ} \mathrm{C}$

- 347

Total dissolved solids (TDS), in ppm

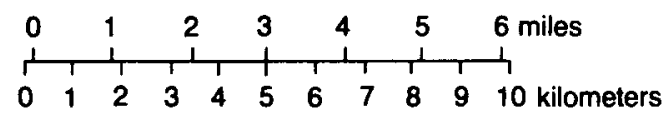

Figure 3. Map showing locations, temperatures (in ${ }^{\circ} \mathrm{C}$ ), and calculated TDS values (in ppm) of spring and well samples in the St. George basin, and locations of temperature-depth logging sites and trilinear diagram groups. 


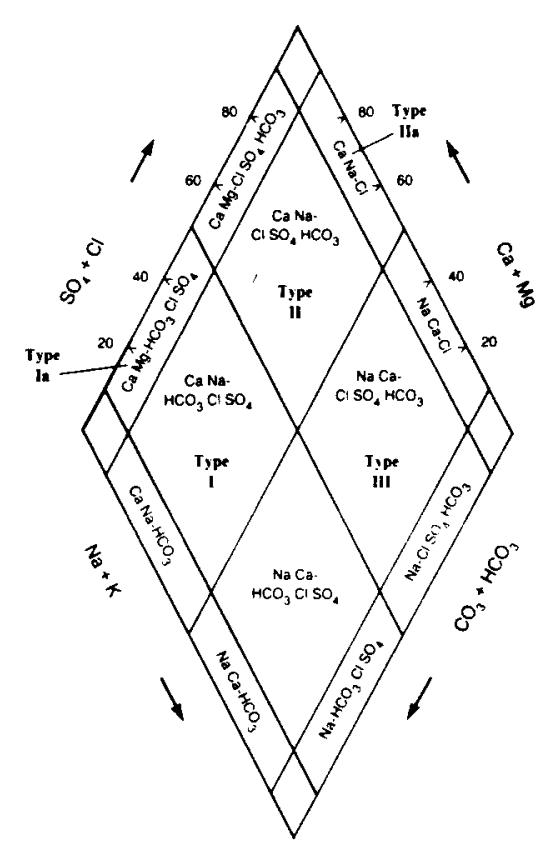

Figure 4. Piper diagram showing nomenclature used to describe water samples from Back (1961) and types of water collected in the St. George basin.

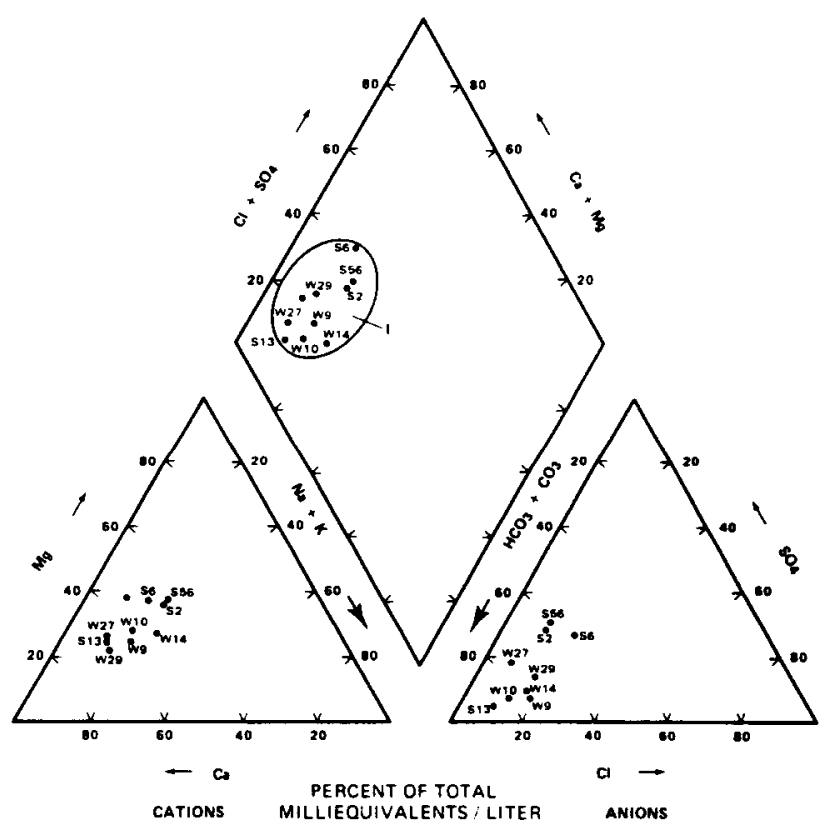

Figure 5. Piper diagram of common ions in samples collected from the northwestern and western portions of the St. George basin.

aquifers that range from 33 to 165 feet $(10-50 \mathrm{~m})$ below the surface.

Figure 9 depicts water chemistry for the southeast corner of the basin; southeast of the Virgin River and east of Warner Ridge. The water is slightly basic with a $\mathrm{pH}$ ranging from 7.5 to

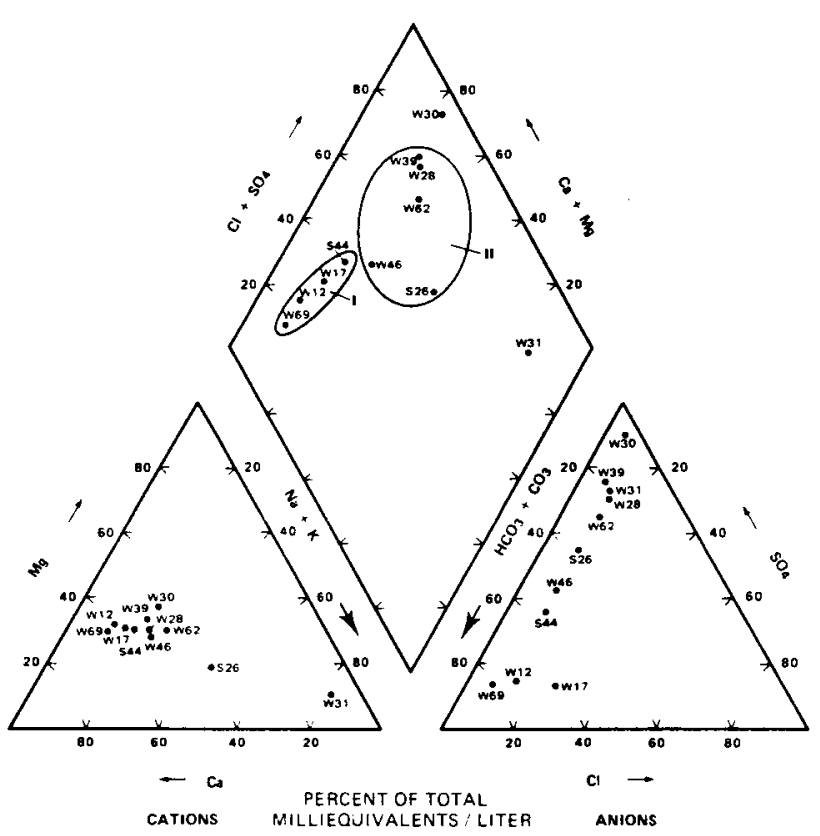

Figure 6. Piper diagram of common ions in samples collected from the west-central portion of the St. George basin.

8.2. Most samples are types I and Il water $\left(\mathrm{Ca}-\mathrm{Na} \mathrm{HCO}_{3}-\mathrm{Cl}-\right.$ $\mathrm{SO}_{4}$ and $\mathrm{Ca}-\mathrm{Na} \mathrm{Cl}-\mathrm{SO}_{4}-\mathrm{HCO}_{3}$ ). Three other samples are type II (S7, W22, W70) but have higher $\mathrm{SO}_{4}$ contents. The wells vary in depth from 148 to 720 feet $(45-220 \mathrm{~m})$, but all are completed in the Navajo Sandstone aquifer approximately 100 feet $(30 \mathrm{~m})$ below the surface. Sample W18 is from a well in the far southeastern corner of the basin that is in the Moenkopi. This water is similar in chemistry to that encountered in the wells drilled in the Moenkopi in the southcentral part of the basin (figure 8 ).

The samples shown in figure 10 were collected north of the Virgin River in the northeastern corner of the basin. Included is a sample (Columbine Spring) from the recharge area in the Pine Valley Mountains (S51) and two Pah Tempe Hot Springs samples (S5, S57). Most samples range in $\mathrm{pH}$ from 7.4 to 8.0; however, Pah Tempe water was 5.9 in March, 1986 and 7.2 in March, 1966. Type I water ( $\mathrm{Ca}-\mathrm{Na} \mathrm{HCO} 3-\mathrm{Cl}-\mathrm{SO}_{4}$ ) is from the vicinity of Anderson Junction, where well water is from the Navajo and the wells are shallow (150 feet $-45 \mathrm{~m})$. The type II water ( $\mathrm{Ca}-\mathrm{Na} \mathrm{Cl}-\mathrm{SO}_{4}-\mathrm{HCO}_{3}$ ) was collected from much deeper wells to the southeast ( 1475 feet $-450 \mathrm{~m}$ in depth) that result in different water chemistry. Pah Tempe Hot Spring water ranges from $\mathrm{Na}-\mathrm{Ca} \mathrm{Cl}$ to $\mathrm{Na}-\mathrm{Ca} \mathrm{Cl}-\mathrm{SO}_{4}-\mathrm{HCO}_{3}$ (type III). The recharge sample from Columbine Spring and the water from well W77, down gradient from the spring, is $\mathrm{Ca}-\mathrm{Mg} \mathrm{HCO} 3$ in character.

In general, type I water ( $\left.\mathrm{Ca}-\mathrm{Na} \mathrm{HCO}_{3}-\mathrm{Cl}-\mathrm{SO}_{4}\right)$ is from aquifers in the Navajo Sandstone and basalt in the northeastern part of the basin, in Snow Canyon, in the Pine Valley Mountains, and near Anderson Junction. Waters from the Sand Mountain area in the Navajo are mostly type II; however some are type $\mathrm{I}$. Most type Il waters $\left(\mathrm{Ca}-\mathrm{Na} \mathrm{Cl}-\mathrm{SO}_{4}-\mathrm{HCO}_{3}\right)$ 


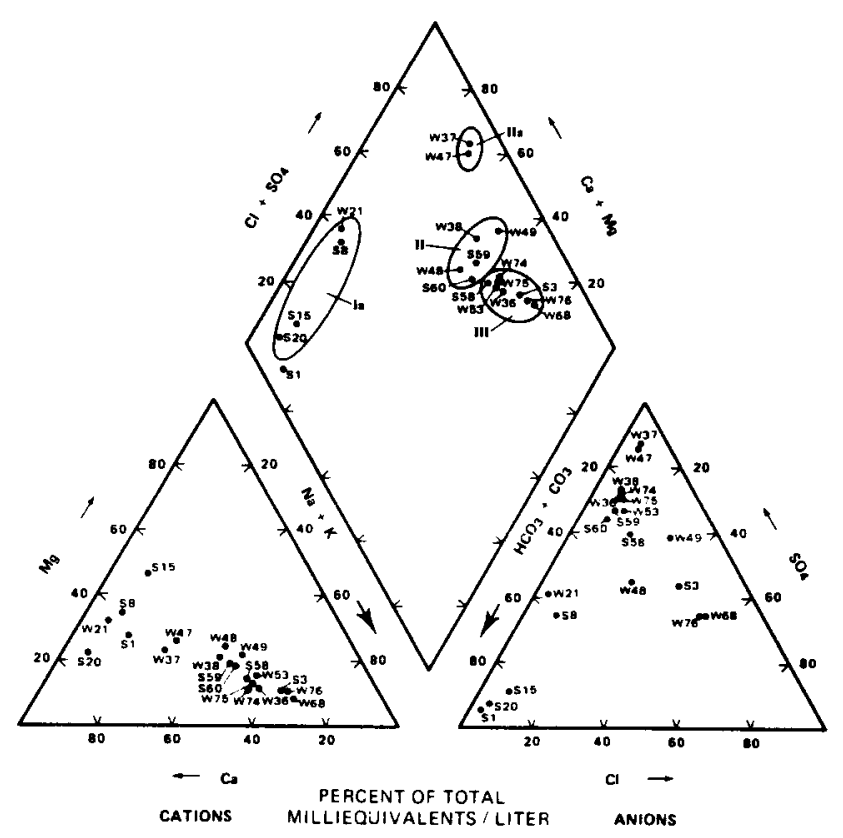

Figure 7. Piper diagram of common ions in samples collected from the central portion of the St. George basin.

are from the shallow alluvial aquifers in the Santa Clara and St. George areas, in addition to water from the Moenkopi Formation in Washington Fields. Type III water ( $\mathrm{Na}-\mathrm{Ca} \mathrm{Cl}-$ $\mathrm{SO}_{4}-\mathrm{HCO}_{3}$ ) is largely from the Navajo Sandstone aquifer north of St. George and Washington.

\section{TOTAL DISSOLVED SOLIDS}

Calculated TDS values in table 1 are determined by summing the constituents with bicarbonate mathematically converted to carbonate; the measured TDS values are determined by weighing the residue after heating. With this method, all bicarbonate is measured as carbonate because the bicarbonate converts to carbonate upon heating. Calculated TDS values, known for all the samples, are discussed in this section and plotted on figure 3 . All concentrations are in ppm (parts per million; equivalent to $\mathrm{mg} / \mathrm{l}$ ).

The total dissolved-solids concentrations (TDS) vary considerably with each aquifer. Lower TDS values, less than 1,000 $\mathrm{ppm}(\mathrm{mg} / \mathrm{l})$, are found in water from aquifers in the Navajo Sandstone and basalt, whereas the Moenkopi and Chinle Formations yield water containing greater than $3,000 \mathrm{ppm}$ $(\mathrm{mg} / \mathrm{l})$. The TDS values generally increase towards the lower elevations (Cordova and others, 1972).

TDS values range from $103 \mathrm{ppm}(\mathrm{mg} / \mathrm{l})$ in the sample from the St. George City aqueduct transporting water from the Pine Valley Mountains to 9,523 ppm (mg/l) at Pah Tempe Hot Springs. The samples collected in recharge areas in the northwest and northeast parts of the basin and from the Sand Mountain area have TDS concentrations in the range of a few hundred ppm and are type I water. These waters are from the Navajo Sandstone, young basalts, and alluvium. Sodium and

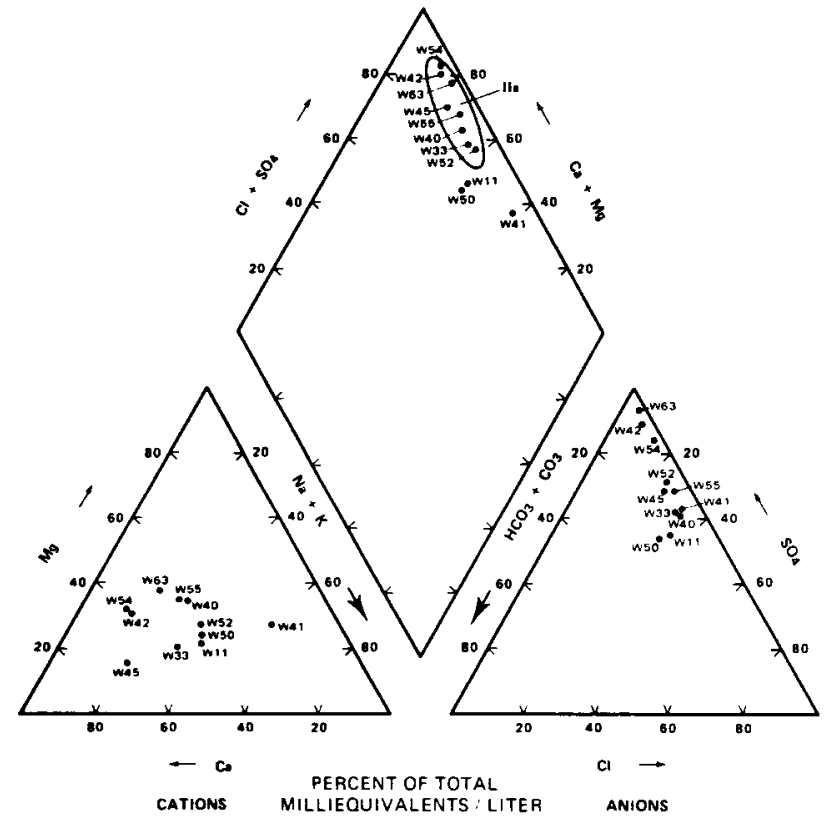

Figure 8. Piper diagram of common ions in samples collected from the south-central portion of the St. George basin.

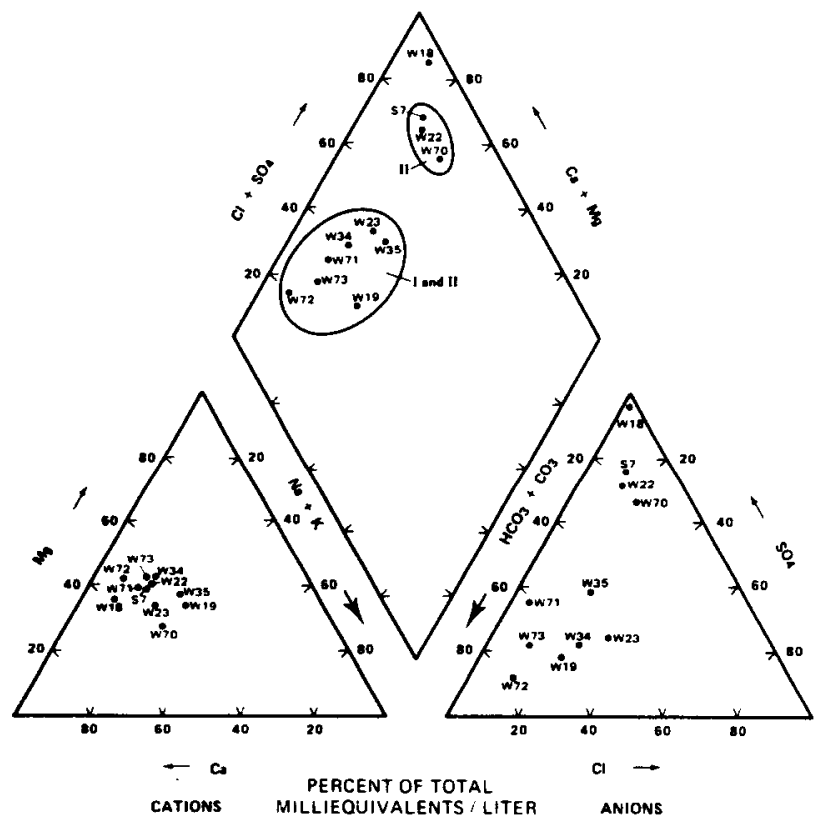

Figure 9. Piper diagram of common ions in samples collected from the southeastern portion of the St. George basin.

chloride constitute the major ions contributing to the TDS at Pah Tempe. Approximately 109,000 tons $(99,000$ metric tons) of dissolved solids flow from the springs annually (Sandberg and Sultz, 1985).

Less than one-third of the samples collected are slightly saline (Hem, 1970), with TDS concentrations ranging from 


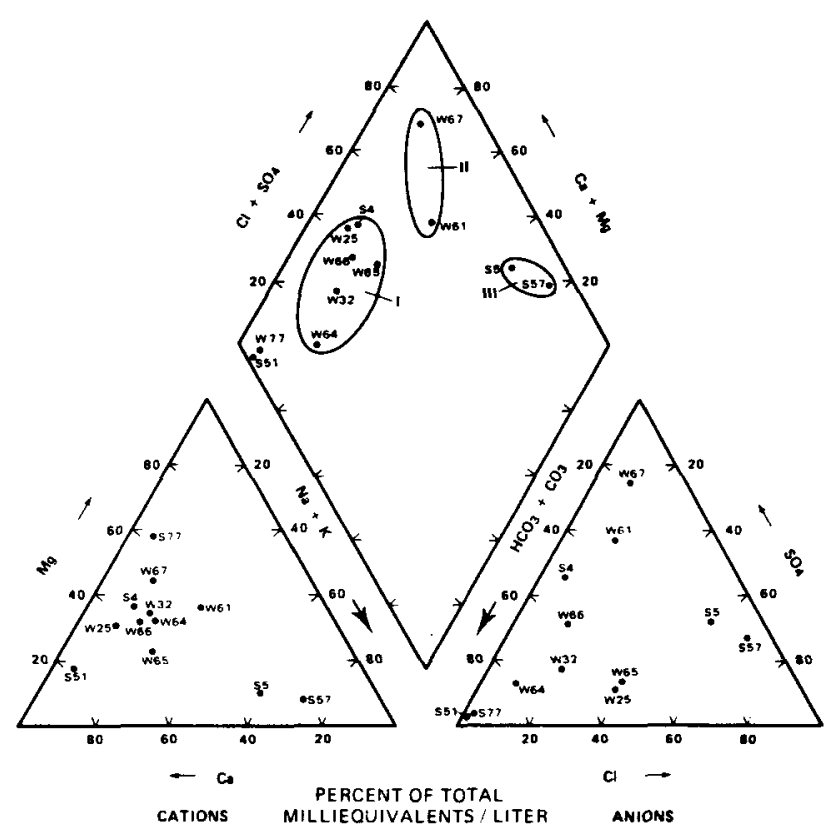

Figure 10. Piper diagram of common ions in samples collected from the northeastern portion of the St. George basin.

1,000 to $3,000 \mathrm{ppm}(\mathrm{mg} / \mathrm{l})$. Most of these samples are type II water and are from the central basin between Santa Clara and Washington, although some samples are from Washington Fields. These waters were collected from shallow alluvial wells underlain by the Chinle Formation or wells completed in the Moenkopi Formation.

Thirteen samples are moderately saline with TDS values between 3,000 and 10,000 ppm (mg/l). As discussed, TDS of the Pah Tempe springs water is at the high end of this range - the two samples reported here being 7,214 and 9,523 ppm (mg/l). Most of the moderately saline water, however, has a TDS range from 3,000 to $4,000 \mathrm{ppm}(\mathrm{mg} / \mathrm{l})$, is largely from Washington Fields, and is type II. Two of the samples are from the Ivins area and one is from Bloomington. These well waters tap aquifers in the Moenkopi.

\section{OTHER ELEMENTS}

Selected elements that are known to be geothermal indicators were plotted against each other in the hopes of distinguishing thermal from non-thermal waters. The plots consisted of $\mathrm{Cl}$ vs $\mathrm{F}$, $\mathrm{Li}$ vs $\mathrm{B}, \mathrm{Na}$ vs $\mathrm{SiO}_{2}$, and calculated TDS vs temperature. Other than the known hot spring samples and certain samples established as anomalous on the basis of other geochemical indicators, no additional anomalous samples were delineated by these plots, thus they are not included.

\section{GEOTHERMOMETRY}

Four geothermometers were used to evaluate low-temperature resource potential of the St. George basin: 1) silicaquartz conductive (Fournier, 198I), 2) silica - chalcedony (Fournier, 1981), 3) Na-K-Ca (Fournier and Truesdell, 1974), and 4) $\mathrm{Na}-\mathrm{K}-\mathrm{Ca}$ with $\mathrm{Mg}$ correction (Fournier and Potter,
1979). The equations for the geothermometers are given below.

Quartz (conductive):

$$
t\left({ }^{\circ} \mathrm{C}\right)=\frac{1309}{5.19-\log \mathrm{SiO}_{2}}-273.15
$$

Chalcedony:

$$
t\left({ }^{\circ} \mathrm{C}\right)=\frac{1032}{4.69-\log \mathrm{SiO}_{2}}-273.15
$$

Na-K-Ca:

$$
t\left({ }^{\circ} \mathrm{C}\right)=\frac{1647}{\log (\mathrm{Na} / \mathrm{K})=\mathrm{B}[\log (\mathrm{Ca} 1 / 2 / \mathrm{Na})+2.06]+2.47}-273.15
$$

$$
\text { where: } \begin{aligned}
& \mathrm{B}=1 / 3 \text { for } \mathrm{t} \text { greater than } 100^{\circ} \mathrm{C} \\
& \mathrm{B}=4 / 3 \text { for } \mathrm{t} \text { less than } 100^{\circ} \mathrm{C} \\
& \mathrm{SiO}_{2} \mathrm{Na}, \mathrm{K} \text {, and } \mathrm{Ca} \text { concentrations are in } \mathrm{mg} / 1
\end{aligned}
$$

If the temperature calculated by the $\mathrm{Na}-\mathrm{K}-\mathrm{Ca}$ geothermometer is less than $100^{\circ} \mathrm{C}$, the silica content of the thermal water is a function of chalcedony and the chalcedony geothermometer should be used; a $\mathrm{Na}-\mathrm{K}-\mathrm{Ca}$ temperature of greater than $100^{\circ} \mathrm{C}$ indicates that the silica temperature should be calculated assuming the silica content is a function of quartz. solubility (Fournier, 1977). The Na-K-Ca geothermometer gives anomalously high results for waters rich in $\mathrm{Mg}$. A $\mathrm{Mg}$ corrected geothermometer should be used when the Na-K-Ca geothermometer calculates a temperature greater than $70^{\circ} \mathrm{C}$ and $\mathrm{R}$ is between 5 and $50, \mathrm{R}=[\mathrm{Mg} /(\mathrm{Mg}+\mathrm{Ca}+\mathrm{K})] \times 100$ using equivalent units of concentration (Fournier and Potter, 1979). A graphical method is used to obtain the temperature; however the ELE program also calculates the temperature.

The geothermometers generally calculate the maximum temperature of the thermal fluids along the water travel path. The reliability of these geothermometers is dependent on five assumptions: 1) temperature-dependent reactions occur at depth;2) an adequate amount of components are available for the temperature-dependent reactions; 3) water-rock chemical equilibrations occur at the reservoir temperature; 4) only minor equilibration occurs at lower temperatures as the water flows from the reservoir to the surface; and 5) hot water rising from depth does not mix with cooler, shallow ground water (Fournier and others, 1974).

When ascending warm water is diluted by cooler water, a new water-rock chemical equilibrium may or may not be attained after mixing. If equilibrium is not reached, the silica geothermometer will calculate a temperature that is too low and mixing must be accounted for by using mixing models (Fournier, 1981). The effect of dilution on the Na-K-Ca geothermometer is generally negligible if the higher temperature geothermal water is more saline than the diluting water. If the warm water component is $\mathbf{3 0}$ percent or less, however, the effects of mixing should be considered. The $\mathrm{Mg}$-corrected $\mathrm{Na}-\mathrm{K}$-Ca geothermometer is subject to error from the continued water-rock reaction as ascending water cools (Fournier, 1981). 
The calculated geothermometer temperatures for the St. George basin samples are presented in table 2 . In most instances the $\mathrm{Na}-\mathrm{K}-\mathrm{Ca}$ and the chalcedony geothermometer temperatures fit the above criteria. Although the majority of the Na-K-Ca calculated reservoir temperatures range between $30^{\circ}$ and $50^{\circ} \mathrm{C}$, a number of samples have anomalously high geothermometer temperatures relative to the other samples and are discussed below.

The water from Pah Tempe Hot Springs has an average calculated reservoir temperature (quartz and $\mathrm{Na}-\mathrm{K}-\mathrm{Ca} \mathbf{M g}$ corrected) of $80^{\circ} \mathrm{C}$. Water at the springs measures $42^{\circ} \mathrm{C}$. Two samples collected in Bloomington (W11, W52) have anomalous Na-K-Ca temperatures. Although the chalcedony geothermometer is the other applicable geothermometer, closer agreement is seen with the quartz temperatures. Average reservoir temperature ( $\mathrm{Na}-\mathrm{K}-\mathrm{Ca}$ and quartz) is $67^{\circ} \mathrm{C}$. The chalcedony temperature average is $29^{\circ} \mathrm{C}$. Surface temperatures measured were $19^{\circ} \mathrm{C}$.

All other anomalous calculated geothermometer temperatures are for samples collected in St. George and vicinity. Four samples in the Washington/Middleton area include two wells (W53, W76) and two springs (S3, S58). The Na-K-Ca Mg corrected and quartz temperatures correlate well and average $67^{\circ} \mathrm{C}$. The chalcedony temperatures vary only slightly and average $32^{\circ} \mathrm{C}$. Measured temperatures ranged from $17^{\circ}$ to $29^{\circ} \mathrm{C}$; the higher temperatures being closer to Washington. Anomalous samples north of St. George include those from City Creek Wells no. 1 and $2(\mathrm{~W} 74, \mathrm{~W} 75, \mathrm{~W} 36)$ at $26^{\circ} \mathrm{C}$, Miller Spring (S26) at $19^{\circ} \mathrm{C}$, and the well in Middleton Wash (W68) that encountered water at $40^{\circ} \mathrm{C}$. The quartz geothermometer calculates the most consistent temperatures for these waters at an average $62^{\circ} \mathrm{C}$. The applicable Na-K-Ca geothermometer averages a higher temperature of $86^{\circ} \mathrm{C}$.

Four out of six samples collected in St. George are anomalous. They include two wells (W38, W47) and two springs on the northern side of the city (S59, S60). Measured temperatures were fairly low $\left(18.5^{\circ}\right.$ to $\left.20^{\circ} \mathrm{C}\right)$; however, the average calculated reservoir temperature from the quartz and applicable Na-K-Ca geothermometers is $65^{\circ} \mathrm{C}$. Southeast of St. George, two wells (W48, W49) have Na-K-Ca temperatures of $88^{\circ}$ and $80^{\circ} \mathrm{C}$, respectively; other geothermometer temperatures for this area are lower. Measured temperatures were $15^{\circ} \mathrm{C}$ for $\mathrm{W} 48$ located just west of the Washington fault, and $24.5^{\circ} \mathrm{C}$ for $\mathrm{W} 49$.

\section{THERMAL GRADIENTS}

Temperature-depth measurements and temperature gradients are useful in exploration for geothermal resources because they can detect thermal anomalies (Laughlin, 1982). Temperature gradients are affected by heat flow and thermal conductivity. For a given heat flow, the temperature gradient is inversely proportional to the thermal conductivity of the material through which the heat is being transmitted by conduction (Kappelmeyer and Haenel, 1974). At shallow depths, temperature gradients are affected by surface conditions such as temperature and precipitation. These effects are eliminated below 65 feet $(20 \mathrm{~m})$ in depth (D.
Chapman, oral communication, 1986). Temperature measurements are strongly influenced by the movement of ground water (sometimes to depths of thousands of meters), and it should always be recognized that temperature gradients are valid only for conductive heat transfer and that vertical as well as horizontal convection can upset the extrapolation of temperature information (Laughlin, 1982; Lumb, 1981).

Temperature-depth measurements were made in 17 shallow water wells and in one deep geothermal exploration well ( 1000 feet $-304 \mathrm{~m}$ in depth) (figure 3 ). The shallow wells ranged in depth from 110 to 550 feet ( $34-162 \mathrm{~m}$ ). Data from well TG-17 (C-40-16) 19aca were not included because the well was blowing air and water was not encountered. A geographic sampling of thermal gradient wells was attempted; however, availability of the wells was the final determining factor. Temperatures were measured with a Fenwal K212E thermistor probe with a nominal resistance of $10,000 \mathrm{ohms}$ at $20^{\circ} \mathrm{C}$, power dissipation of $50 \mathrm{~mW} \mathrm{~K}^{-1}$ in still water, and a response time of five seconds. Resistances were measured with a Hewlett-Packard digitial ohm-meter. Measurements were taken at 5-meter (16.4-ft) intervals beginning at the water table, after the temperature had stabilized at each position. Unusual readings were supplemented by additional measurements at 2.5 -meter (8.2-ft) intervals. Gradients were calculated using linear regression and the error reported is the standard error of estimate. Table 3 lists the gradients calculated and the depth interval for the calculations. Temperature-depthprofiles for all wells, grouped by proximity, are plotted in figures 11 through 15 . The temperature-depth profile data along with the ambient temperatures measured at each site are contained in table 4.

The average thermal gradient for the Colorado Plateau is from $0.82^{\circ}$ to $1.09^{\circ} \mathrm{F} / 100$ feet $\left(15^{\circ}-20^{\circ} \mathrm{C} / \mathrm{km}\right)$, in contrast with $1.65^{\circ}$ to $2.19^{\circ} \mathrm{F} / 100$ feet $\left(30^{\circ}-40^{\circ} \mathrm{C} / \mathrm{km}\right)$ for the Basin and Range Province; however, these values are dependent on rock type and associated thermal conductivity (D. Chapman, oral communication, 1986). Gradients were calculated for six of the 17 wells; they ranged from $1.01^{\circ}$ to $1.85^{\circ} \mathrm{F} / 100$ feet $\left(18.5^{\circ}\right.$ $-33.7^{\circ} \mathrm{C} / \mathrm{km}$ ) (table 3). Most gradients are from $0.98^{\circ}$ to $1.31^{\circ} \mathrm{F} /$ feet $\left(18^{\circ}-24^{\circ} \mathrm{C} / \mathrm{km}\right)$, although well TG12 is considerably higher with a gradient of $1.85^{\circ} \mathrm{F} / 100$ feet $\left(33.7^{\circ} \mathrm{C} / \mathbf{k m}\right)$.

The density of available wells for temperature-depth measurements was greatest south of Washington Fields. Gradients ranging from $1.06^{\circ}$ to $1.31^{\circ} \mathrm{F} / 100$ feet $\left(19.3^{\circ}\right.$ $23.9^{\circ} \mathrm{C} / \mathrm{km}$ ) were calculated for this area for TG1, TG3, TG5, and TG7 (figures 11 and 12). The gradient of $1.19^{\circ} \mathrm{F} / 100$ feet $\left(21.8^{\circ} \mathrm{C} / \mathrm{km}\right)$ calculated for TG3 projects back to the surface to a temperature close to the measured ambient temperature of $17^{\circ} \mathrm{C}$. The decrease in temperature seen in the four readings near the surface may indicate fractured bedrock within the aquifer. A similar decrease in temperature measured at the bottom of well TG5. gradient $1.22^{\circ} \mathrm{F} / 100$ feet $\left(22.3^{\circ} \mathrm{C} \mathrm{km}\right)$, may reflect a circulation problem at the bottom of the well or perhaps a cold-water aquifer. Although the temperaturedepth profile for well TG7 is somewhat irregular, an overall increase in temperature with depth is seen and the calculated 

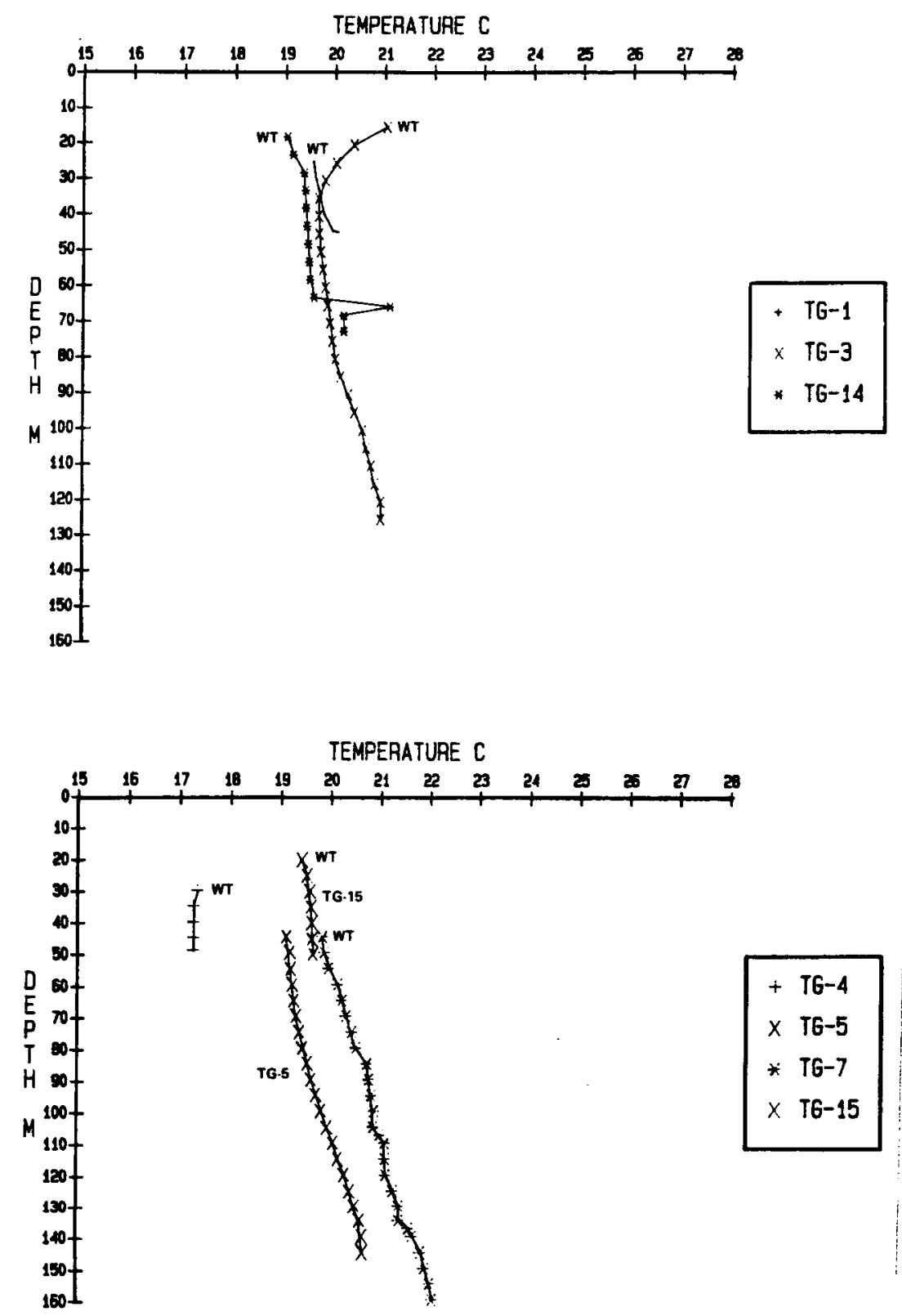

Figure 11.

Temperature-depth profiles TG1, TG3, and TG14 logged south of Washington Fields in the St. George basin. gradient is $1.06^{\circ} \mathrm{F} / 100$ feet $\left(19.3^{\circ} \mathrm{C} / \mathrm{km}\right)$. Gradients were not calculated for TG4, TG14, and TG15 because the plots are largely isothermal. The higher temperature recorded near the bottom of TG14 may reflect a thin, warm zone and subsequent mixing of the two waters in the intermediate temperatures measured below the aquifer.

Temperature-depth data collected in the eastern part of the basin south of Berry Springs (TG9 - TG13) is plotted on figures 13 and 14. A gradient was only calculated for TG12 which, at $1.85^{\circ} \mathrm{F} / 100$ feet $\left(33.7^{\circ} \mathrm{C} / \mathrm{km}\right)$, is the highest gradient determined in the basin. Although the validity of the gradient is uncertain because the well is shallow, the gradient projects back to the surface at close to the mean annual temperature in the basin of $16.5^{\circ} \mathrm{C}$. Wells TG9, TG10, TG11, and TG13 are largely isothermal. TG9 was drilled in an unsuccessful attempt to locate warm water to heat a greenhouse. The increase in temperature above the isothermal section in TG10 (from 115 to 210 feet -35 to $64 \mathrm{~m}$ ) may reflect surface cooling effects. TG11 and TG13 are very shallow and are affected by variations in surface temperatures as well as convection within the wells.

Figure 14 also includes wells from locations throughout the basin. A gradient of $1.01^{\circ} \mathrm{F} / 100$ feet $\left(18.5^{\circ} \mathrm{C} / \mathrm{km}\right)$ was calculated for TG8, approximately 5.6 miles $(9 \mathrm{~km})$ south of Hurricane. Although TG16 (north of Washington) is isothermal, the temperature is high $\left(27^{\circ} \mathrm{C}\right)$. A water sample 

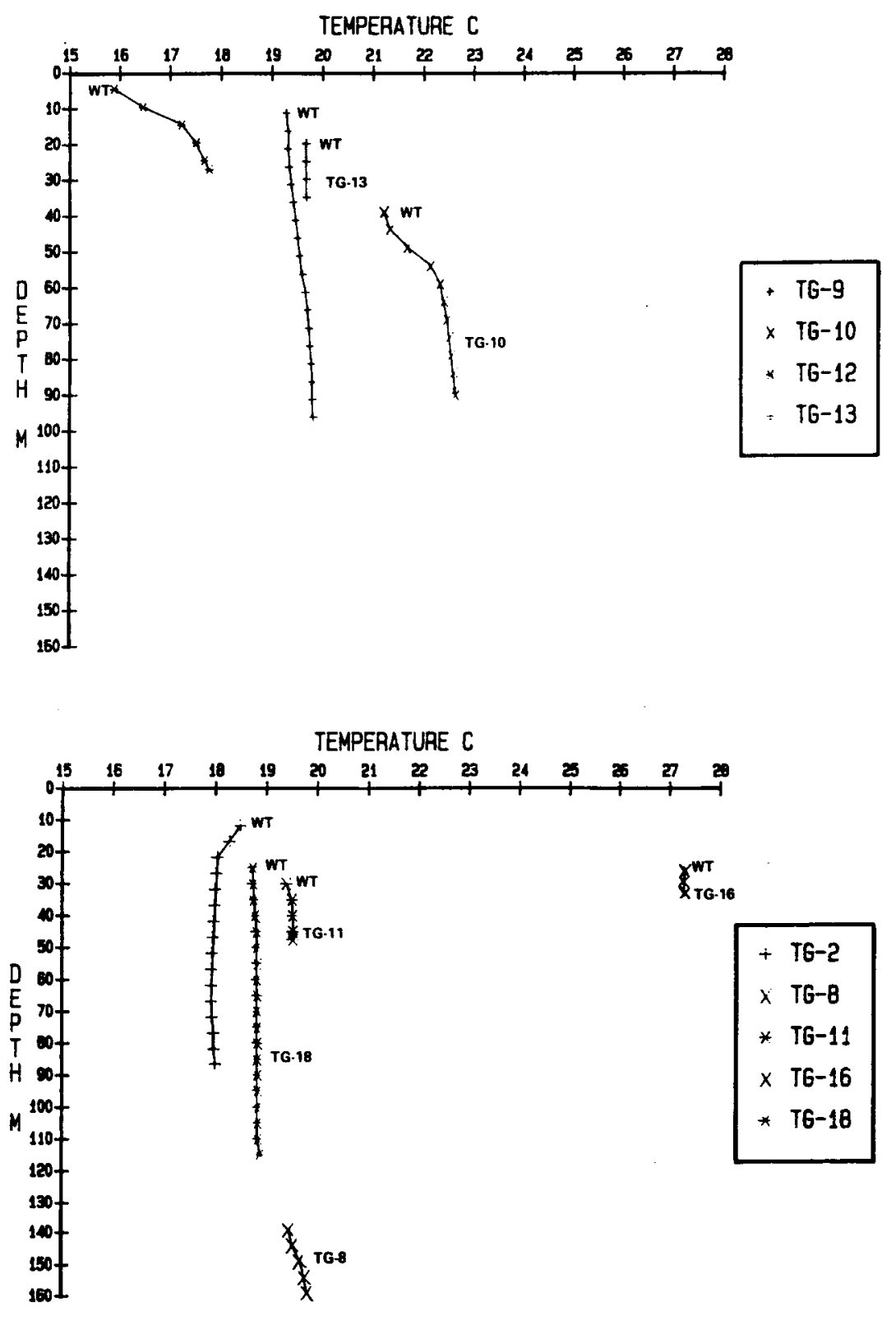

Figure 13

Temperature-depth profiles TG9 through TG13 logged south of Berry Springs and Washington Fields in the St. George basin.
Figure 14.

Temperature-depth profiles TG2, TG8, TG11, TG16, and TG18 logged in scattered locations in the St. George basin. collected from this well in 1974 is included in this study (W76); a high water temperature of $20^{\circ} \mathrm{C}$ was reported previously. Isothermal plots for TG2, north of Bloomington, and TG18, northwest of St. George, indicate circulation within these wells. A shallow warm water zone may be causing the higher temperatures from 35 to $65 \mathrm{feet}(10-20 \mathrm{~m})$ at depth in TG2.

Temperature-depth measurements shown in figure 15 for TG6 were made in a Phillips Petroleum Company deep geothermal exploration well drilled southeast of Veyo. All measurements were in air as water was not encountered. The bottom-hole temperature measured was $69.6^{\circ} \mathrm{C}$; however, a gradient could not be calculated because the data may be erroneous due to the convection, particularly in the near-surface.

\section{SUMMARY AND CONCLUSIONS}

In addition to the known thermal areas of Pah Tempe and Veyo Hot Springs, an area north of Washington and St. George is delineated in this study to have possible lowtemperature geothermal potential. This area is distinguished on the basis of both anomalous surface and calculated geothermometer temperatures. The thermal area at the Washington hot pot can be extended westward to include the area encompassed by samples (north to south) W76, S3, S58, and W53 (figure 3). West of this area and north of St. George, additional high temperatures were found (W36, W74, W75, W68).

The realized or potential low-temperature geothermal resource areas within the $\mathrm{St}$. George basin appear to be related 


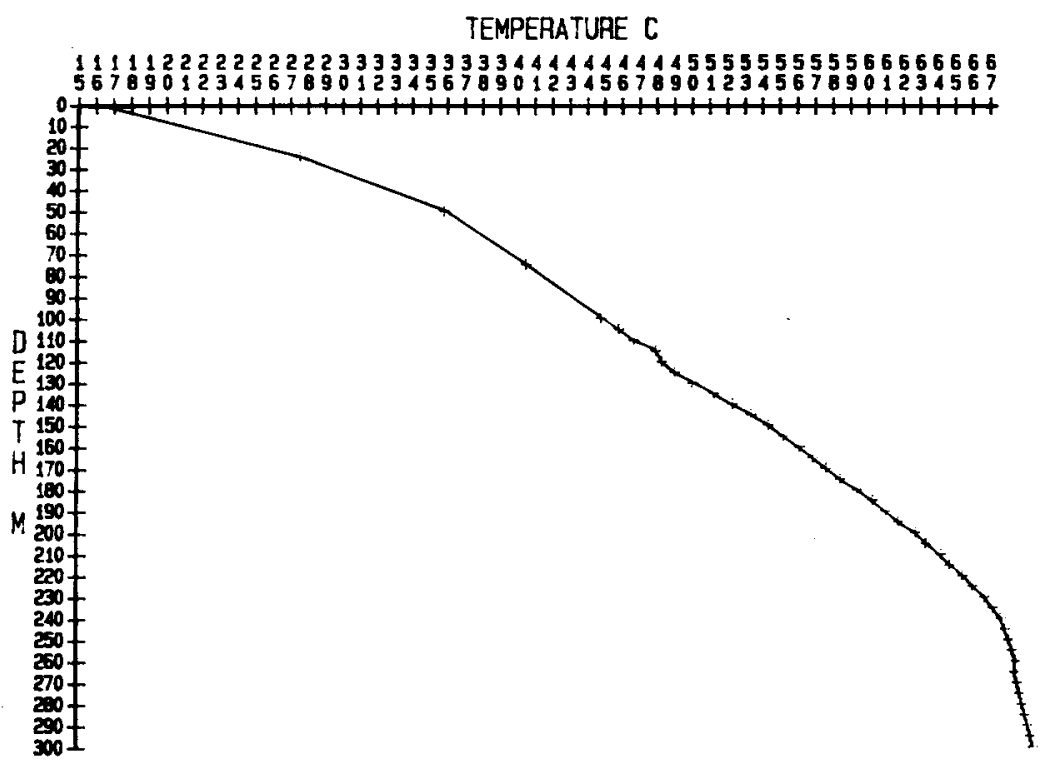

Figure 15.

Temperature-depth profile TG6 logged southeast of Veyo in the St. George basin. to structure, not to recent igneous activity. Extensive Quaternary and Tertiary basalts in the basin, some less than 1,000 years old, indicate recent volcanism in the area and possibly some associated heat. The basalt probably originated at considerable depth, however, and was erupted at the surface through narrow conduits, thus most heat transferred from the deep heat reservoir was dissipated into the atmosphere as the basalt flow cooled. Feeder dikes for comparative basalt flows in the Grand Canyon are only 3.2 feet $(1 \mathrm{~m})$ wide and have no associated wallrock alteration. Basalt erupted on the Uinkaret Plateau in Arizona and its northward extension into Utah locally contains mantle-derived peridotitic inclusions (Best and Hamblin, 1978). The Uinkaret basalt is equivalent to Stage IV flows west of Hurricane in the St. George basin. The dacite northeast of Central, near Veyo Hot Spring, probably originated from a magma body at much shallower depths than the basalt; however, the $3.1 \mathrm{~m}$.y.-old age suggests that the parent body is no longer a local source of heat.

The three major faults in the basin that appear to have some control on the thermal areas (the Hurricane, Gunlock, and Washington faults) are not spatially related to the basalt. The extrusive vents of the basalt are located between the major fault lines and are independent of them. The faults are thought to be listric, thus the shallow faulting probably did not serve as conduits for ascending magma (Best and Hamblin, 1970). The wide-spread basalt that erupted along margins of the Pine Valley Mountains intrusion probably utilized zones of weakness caused by the intrusion. Quaternary movement has been documented along the Hurricane and Washington faults and evidence of late Tertiary movement is found along the Gunlock fault. All three faults are considered to be seismically active and are present in an area of relatively high heat flow.

The Hurricane fault consists of several fault planes in a zone of displacement ranging up to one mile wide $(1.6 \mathrm{~km})$ in the gorge of the Virgin River near Hurricane (Hamblin, 1970b). Intense fracturing within the fault zone, in addition to the small horst and graben structures produced from reverse drag on the fault, provide many conduits for the transport of water from depth to feed Pah Tempe Hot Springs at the surface. Near-surface cavernous porosity within the Toroweap Limestone may facilitate high flow rate of the deep-seated water at the springs and the high water pressure may be due to the pressure head from the recharge area. Veyo Hot Springs is not as close to a major fault as is the case with Pah Tempe Springs; however, located 2.8 miles ( $4.5 \mathrm{~km}$ ) east of the Gunlock fault, it is within the Gunlock fault zone. The highly fractured basalt provides good conduits for the water that may be heated by the normal geothermal gradient. The known geothermal area north of Washington, and the extension of that area as suggested by the data presented in this study, are probably related to water heated at depth and transported to the surface along the Washington fault. The westernmost limit of this area is approximately 3 miles $(5 \mathrm{~km})$ west of the Washington fault. Lateral movement in near-surface aquifers may be involved in producing this thermal anomaly.

Veyo and Pah Tempe Hot Springs are currently developed as swimming pools and mineral baths. The temperature and high flow rate at Pah Tempe suggest that other geothermal applications of the resource may be possible, particularly with the recently developed technology in harnessing this energy. The low-temperature geothermal potential of the area north of Washington and St. George could better be assessed by a study to 1) determine the structural controls on the thermal fluids, 2) delineate the distribution of these fluids in the near surface, and 3) determine the maximum temperature and volume of these fluids.

This low-temperature geothermal assessment is only a reconnaissance appraisal of the geothermal potential of the St. George basin. The lack of evidence for additional geothermal anomalies does not eliminate the possibility that additional resources exist. 


\section{ACKNOWLEDGMENTS}

The authors are sincerely grateful for the guidance and assistance provided by Robert Klauk, UGMS. We relied heavily on his geothermal expertise. Thanks are also due to Miriam Bugden, UGMS, who painstakingly entered all the geochemical data into the data base. John Hand, UGMS, assisted in computer applications. Don Mabey, UGMS, was consulted on the gravity and aeromagnetic data. Ruth Kroneman and others at ESL/UURI performed the water analyses and calculated the geothermometers. Dave Chapman, University of Utah, provided the use of his thermal gradient equipment. John Mann, Utah Water Rights, Salt Lake City, helped locate evasive lithologic logs. Thanks are extended to Glen Gubler, City Water Superintendant, St. George; Gerald Stoker, Utah Water Rights, Cedar City; Woody Sandberg, USGS Water Resources, Cedar City; and Jerry Olds, Utah Water Rights, Salt Lake City; for information on well and spring locations and sampling accessibility. Ken Hamblin, BYU, generously offered us the use of his unpublished geologic maps and provided insight on the geology of the field area. Lastly we would like to thank the many people in the St. George basin who graciously allowed us to sample their springs and wells.

\section{WELL AND SPRING NUMBERING-SYSTEMS USED IN UTAH}

The system of numbering wells and springs in Utah is based on the cadastral land-survey system of the U.S. Government. The number designates a location and describes its position in the land net. The land-survey system divides the state into four quadrants by the Salt Lake Base Line and Meridian, and these quadrants are designated by uppercase letters as follows: $A$, northeast; B, northwest; C, southwest; and D, southeast.
Numbers designating the township and range (in that order) follow the quadrant letter, and all three are enclosed in parentheses. The number after the parentheses indicates the section and is followed by the three letters indicating the quarter section, the quarter-quarter section, and the quarterquarter-quarter section-generally 10 acres $(4 \mathrm{~km} 2)$. The quarters of each subdivision are designated by lowercase letters as follows: a, northeast; b, northwest; c, southwest; and d, southeast.

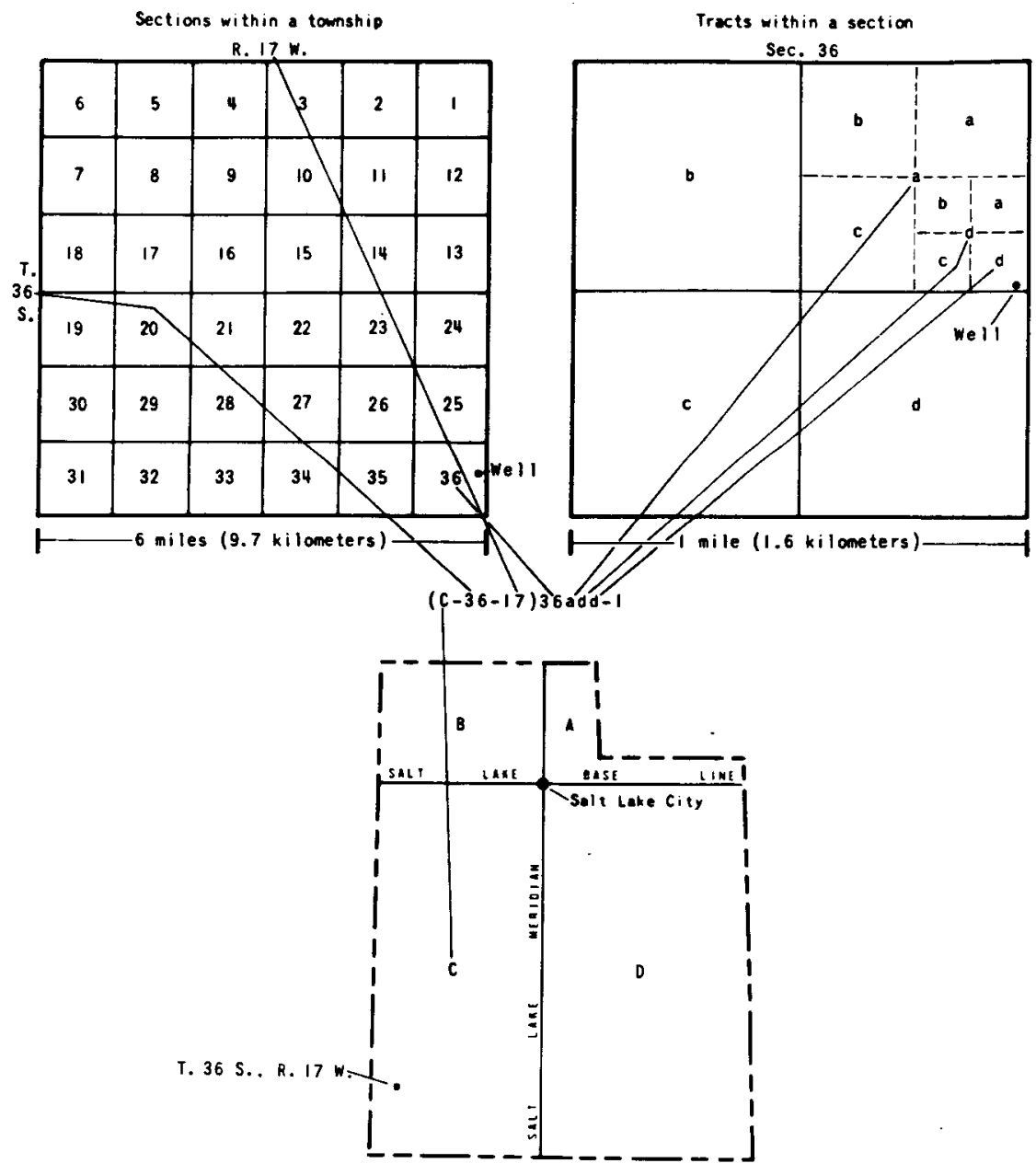


Table 1. Chemical analyses of spring and well water samples collected in the study area and taken from the literature; $S$ preceding sample number denotes spring sample; $W$ preceding sample number denotes well sample; all concentrations in ppm; detection limit (given in parentheses) follows element; ND denotes less than detection limits. Precision of the analytical values, with the exception of TDS, at an order of magnitude greater than the detection limits is approximately $\pm 2 \%$ of the given value at a confidence value of $95 \%$; TDS is approximately $\pm 5 \%$ of the given value. The following elements were analyzed for but were below the detection limit (given in parentheses): Ag (0.05), As (0.61), Au (0.10), Ba (0.61), Be(0.0), Bi (2.44), Cd(0.06), Ce(0.24), Co(0.02), Cr (0.05), Cu(0.06), La (0.12), Mo (1.22), Pb (0.24), Sn (0.12), Sb (0.73), Te (1.22), Th (2.44), Ti (0.12), U (6.10), V (1.22), W (0.12), Zr (0.12), CO $(10.00)$.

\begin{tabular}{|c|c|c|c|c|c|c|}
\hline $\begin{array}{l}\text { Sample \# } \\
\text { Location } \\
\text { Name/Owner } \\
\text { Reference }\end{array}$ & $\begin{array}{l}\text { S1 } \\
\text { (C-42-15)18ddb } \\
\text { St. George City } \\
\text { Aqueduct }\end{array}$ & $\begin{array}{l}\text { S2 } \\
\text { (C-40-16)6dbc } \\
\text { Veyo Hot } \\
\text { Spring }\end{array}$ & $\begin{array}{l}\text { S3 } \\
\text { (C-42-15)15bba } \\
\text { Green } \\
\text { Spring }\end{array}$ & $\begin{array}{l}\text { S4 } \\
\text { (C-40-13)35acd } \\
\text { Toquerville } \\
\text { Spring }\end{array}$ & $\begin{array}{l}\text { S5 } \\
\text { (C-41-13)25cca } \\
\text { Pah Tempe Hot } \\
\text { Springs }\end{array}$ & $\begin{array}{l}\text { S6 } \\
\text { (C-41-18)2ddc } \\
\text { Pahcoon } \\
\text { Spring }\end{array}$ \\
\hline Date & $02-04-86$ & $02-05-86$ & $02-06-86$ & $02-06-86$ & $02-06-86$ & $02-07-86$ \\
\hline Temp $\left({ }^{\circ} \mathrm{C}\right)$ & 18.5 & 29.5 & 23 & 16.5 & 42 & 16.5 \\
\hline $\mathrm{pH}$ & 8.4 & 7.5 & 7.0 & 7.7 & 5.9 & 7.5 \\
\hline CalcTDS & 103 & 395 & 1239 & 459 & 7214 & 386 \\
\hline MeasTDS & 108 & 408 & 1248 & 480 & 7388 & 107 \\
\hline $\mathrm{Na}(0.61)$ & 5.25 & 31.60 & 274.00 & 21.00 & 1587.00 & 24.90 \\
\hline $\mathbf{K}(1.22)$ & ND & 3.82 & 24.10 & 2.87 & 120.00 & 2.19 \\
\hline $\mathrm{Ca}(0.24)$ & 18.20 & 56.30 & 104.00 & 74.00 & 740.00 & 57.00 \\
\hline $\mathrm{Mg}(0.49)$ & 4.96 & 28.40 & 22.70 & 30.70 & 130.00 & 27.00 \\
\hline $\mathrm{Fe}(0.02)$ & 0.13 & ND & ND & ND & ND & ND \\
\hline $\mathrm{Al}(0.61)$ & ND & ND & ND & ND & ND & ND \\
\hline $\mathrm{SiO}_{2}(0.52)$ & 25.30 & 38.10 & 21.80 & 43.90 & 27.00 & 45.20 \\
\hline B $(0.12)$ & ND & ND & 0.37 & ND & 2.40 & ND \\
\hline $\mathrm{Li}(0.05)$ & ND & ND & 0.28 & ND & 1.57 & 0.06 \\
\hline $\operatorname{Sr}(0.01)$ & 0.10 & 0.69 & 1.62 & 0.80 & 8.88 & 1.16 \\
\hline $\mathrm{Zn}(0.12)$ & ND & ND & ND & ND & ND & ND \\
\hline $\operatorname{Mn}(0.24)$ & ND & ND & ND & ND & ND & ND \\
\hline $\mathrm{Ni}(0.12)$ & ND & ND & ND & ND & ND & ND \\
\hline $\mathrm{HCO}_{3}(10.00)$ & 90.00 & 245.00 & 234.00 & 219.00 & 1104.00 & 203.00 \\
\hline $\mathrm{SO}_{4}(2.00)$ & 3.00 & 86.00 & 404.00 & 160.00 & 1802.00 & 77.00 \\
\hline $\mathrm{Cl}(2.00)$ & 2.00 & 29.50 & 270.00 & 18.00 & 2250.00 & 48.00 \\
\hline $\mathrm{PO}_{4}(1.84)$ & ND & ND & ND & ND & ND & ND \\
\hline$F(0.10)$ & ND & 0.34 & 1.29 & 0.20 & 2.70 & 0.62 \\
\hline $\begin{array}{l}\text { Sample \# } \\
\text { Location } \\
\text { Name/Owner } \\
\text { Reference } \\
\end{array}$ & $\begin{array}{l}\text { S7 } \\
\text { (C-42-14)1bcb } \\
\text { Berry Spring }\end{array}$ & $\begin{array}{l}\text { S8 } \\
\text { (C-42-15)11cec } \\
\text { Washington } \\
\text { bot pot }\end{array}$ & $\begin{array}{l}\text { W9 } \\
\text { (C-39-16)3ded } \\
\text { Dixie Deer } \\
\text { Water Co. }\end{array}$ & $\begin{array}{l}\text { W10 } \\
\text { (C-39-16)28bed } \\
\text { Pine Valley } \\
\text { Mtn. Farm }\end{array}$ & $\begin{array}{l}\text { W11 } \\
\text { (C-43-16)12adc } \\
\text { Bloomington } \\
\text { Water Co. }\end{array}$ & $\begin{array}{l}\text { W12 } \\
\text { (C-41-16)16edb } \\
\text { St. George City } \\
\text { Snow Cyn. \#1 }\end{array}$ \\
\hline Date & $02-24-86$ & $02-24-86$ & $02-25-86$ & $02-25-86$ & $02-25-86$ & $02-25-86$ \\
\hline $\operatorname{Temp}\left({ }^{\circ} \mathrm{C}\right)$ & 18.5 & 24.5 & 9.0 & 12.0 & 19.0 & 18.00 \\
\hline pH & 7.9 & 7.7 & 7.4 & 7.6 & 7.3 & 7.8 \\
\hline CalcTDS & 1349 & 311 & 347 & 317 & 2214 & 114 \\
\hline MeasTDS & 1490 & 338 & 316 & 316 & 2266 & 142 \\
\hline $\mathrm{Na}$ & 73.00 & 9.20 & 22.00 & 21.00 & 298.00 & 4.30 \\
\hline $\mathbf{K}$ & 12.00 & 3.10 & 3.00 & 2.00 & 21.00 & 2.00 \\
\hline $\mathrm{Ca}$ & 192.00 & 62.00 & 64.00 & 59.00 & 288.00 & 21.70 \\
\hline $\mathbf{M g}$ & 97.00 & 22.00 & 17.00 & 18.00 & 84.00 & 7.20 \\
\hline $\mathrm{Fe}$ & ND & ND & ND & ND & ND & ND \\
\hline $\mathrm{Al}$ & ND & ND & ND & ND & ND & ND \\
\hline $\mathrm{SiO}_{2}$ & 26.00 & 18.00 & 58.00 & 43.00 & 20.00 & 12.00 \\
\hline $\mathrm{B}^{2}$ & 0.20 & ND & ND & ND & 0.50 & ND \\
\hline $\mathbf{L i}$ & 0.07 & ND & ND & ND & 0.27 & ND \\
\hline Sr & 3.31 & 0.61 & 0.31 & 0.29 & 4.08 & 0.80 \\
\hline $\mathrm{Zn}$ & ND & ND & ND & ND & ND & ND \\
\hline $\mathrm{Mn}$ & ND & ND & ND & ND & ND & ND \\
\hline $\mathrm{Ni}$ & ND & ND & ND & ND & ND & ND \\
\hline $\mathrm{HCO}_{3}$ & 196.00 & 189.00 & 257.00 & 266.00 & 314.00 & 88.00 \\
\hline $\mathrm{SO}_{4}$ & 768.00 & 86.00 & 19.00 & 17.00 & 935.00 & 13.00 \\
\hline $\mathrm{Cl}^{4}$ & 81.00 & 17.00 & 37.00 & 23.00 & 408.00 & 10.00 \\
\hline $\mathrm{PO}_{4}$ & ND & ND & ND & ND & ND & ND \\
\hline $\mathbf{F}$ & 0.40 & 0.30 & 0.20 & 0.20 & 0.40 & 0.20 \\
\hline
\end{tabular}




\begin{tabular}{|c|c|c|c|c|c|c|}
\hline $\begin{array}{l}\text { Sample \# } \\
\text { Location } \\
\text { Name/Owner } \\
\text { Reference } \\
\end{array}$ & $\begin{array}{l}\text { S13 } \\
\text { (C-39-16)14dab } \\
\text { Nervine } \\
\text { Spring }\end{array}$ & $\begin{array}{l}\text { WI4 } \\
\text { (C-36-16)3ddd } \\
\text { Central } \\
\text { Water Co. }\end{array}$ & $\begin{array}{l}\text { S15 } \\
\text { (C-40-16)36eda } \\
\text { Diamond } \\
\text { Valley }\end{array}$ & $\begin{array}{l}\text { W16 } \\
\text { (C-40-16)9adb } \\
\text { Dameron } \\
\text { Valley }\end{array}$ & $\begin{array}{l}\text { W17 } \\
\text { (C-41-16)9cbb } \\
\text { St.George City } \\
\text { Snow Cyn. \#3 }\end{array}$ & $\begin{array}{l}\text { W18 } \\
\text { (C-43-13)21cea } \\
\text { W. Spendlove }\end{array}$ \\
\hline Date & $02-26-86$ & $02-26-86$ & $02-26-86$ & $02-26-86$ & $02-26-86$ & $02-27-86$ \\
\hline Temp $\left({ }^{\circ} \mathrm{C}\right)$ & 9.0 & 16.00 & 15.00 & 26.5 & 20.0 & 17.0 \\
\hline $\mathrm{pH}$ & 7.4 & 7.3 & 7.5 & 7.7 & 8.0 & 7.6 \\
\hline CalcTDS & 304 & 465 & 270 & 224 & 117 & 2583 \\
\hline MeasTDS & 282 & 464 & 258 & 210 & 119 & 2742 \\
\hline $\mathbf{N a}$ & 14.00 & 42.00 & 10.00 & 9.00 & 6.00 & 83.00 \\
\hline $\mathbf{K}$ & 2.00 & 7.00 & 4.00 & 3.00 & 2.00 & 10.00 \\
\hline $\mathrm{Ca}$ & 62.00 & 78.00 & 44.00 & 41.00 & 21.00 & 447.00 \\
\hline $\mathrm{Mg}$ & 14.00 & 25.00 & 27.00 & 18.00 & 7.00 & 170.00 \\
\hline $\mathrm{Fe}$ & ND & ND & ND & ND & ND & 0.06 \\
\hline Al & ND & ND & ND & ND & ND & ND \\
\hline $\mathrm{SiO}_{2}$ & 53.00 & 58.00 & 17.00 & 25.00 & 15.00 & 20.00 \\
\hline B & ND & ND & ND & ND & ND & 0.40 \\
\hline $\mathrm{Li}$ & ND & 0.05 & ND & ND & ND & 0.12 \\
\hline $\mathrm{Sr}$ & 0.27 & 0.48 & 0.21 & 0.18 & 0.10 & 6.02 \\
\hline$Z_{n}$ & ND & ND & ND & ND & ND & ND \\
\hline Mn & ND & ND & ND & ND & ND & 0.30 \\
\hline $\mathrm{Ni}$ & ND & ND & ND & ND & ND & ND \\
\hline $\mathrm{HCO}_{3}$ & 266.00 & 356.00 & 261.00 & 199.00 & 74.00 & 96.00 \\
\hline $\mathrm{SO}_{4}$ & 7.40 & 32.00 & 24.00 & 17.00 & 11.00 & 1768.00 \\
\hline $\mathrm{Cl}$ & 20.00 & 47.00 & 15.00 & 13.00 & 18.00 & 30.00 \\
\hline $\mathrm{PO}_{4}$ & ND & ND & ND & ND & ND & ND \\
\hline $\mathbf{F}$ & 0.20 & 0.70 & 0.30 & 0.20 & 0.20 & 0.70 \\
\hline $\begin{array}{l}\text { Sample \# } \\
\text { Location } \\
\text { Name/Owner } \\
\text { Reference } \\
\end{array}$ & $\begin{array}{l}\text { W19 } \\
\text { (C-42-13)30adc } \\
\text { M. Longley }\end{array}$ & $\begin{array}{l}\text { S20 } \\
\text { (C-39-15)22dad } \\
\text { Cougar } \\
\text { Spring }\end{array}$ & $\begin{array}{l}\text { W21 } \\
\text { (C-42-15)3dan } \\
\text { Washington } \\
\text { City }\end{array}$ & $\begin{array}{l}\text { W22 } \\
\text { (C-42-14)15aba } \\
\text { Stratton } \\
\text { Turf Farm }\end{array}$ & $\begin{array}{l}\text { W23 } \\
(C-42-14) 14 b c c \\
\text { Stratton } \\
\text { Turf Farm }\end{array}$ & $\begin{array}{l}\text { W24 } \\
\text { (C-41-13)5ana } \\
\text { R. Harper }\end{array}$ \\
\hline Date & $02-28-86$ & $02-24-86$ & $02-25-86$ & $02-25-86$ & $02-25-86$ & $02-25-86$ \\
\hline $\operatorname{Temp}\left({ }^{\circ} \mathrm{C}\right)$ & 18.5 & 7.0 & 12.0 & 21.0 & 20.0 & 17.5 \\
\hline $\mathrm{pH}$ & 8.1 & 8.2 & 8.2 & 7.8 & 8.2 & 7.8 \\
\hline CalcTDS & 233 & 248 & 300 & 1177 & 325 & 530 \\
\hline MeasTDS & 220 & 232 & 296 & 1284 & 318 & 528 \\
\hline $\mathrm{Na}$ & 27.00 & 7.00 & 71.00 & 71.00 & 29.00 & 73.00 \\
\hline $\mathbf{K}$ & 2.00 & ND & 2.00 & 8.00 & ND & ND \\
\hline $\mathrm{Ca}$ & 31.00 & 61.00 & 62.00 & 161.00 & 52.00 & 79.00 \\
\hline $\mathbf{M g}$ & 17.00 & 11.00 & 19.00 & 90.00 & 23.00 & 23.00 \\
\hline $\mathrm{Fe}$ & ND & ND & ND & ND & ND & ND \\
\hline Al & ND & ND & ND & ND & ND & ND \\
\hline $\mathrm{SiO}_{2}$ & 14.00 & 27.00 & 16.00 & 23.00 & 15.00 & 34.00 \\
\hline $\mathrm{B}^{2}$ & ND & ND & ND & 0.20 & ND & ND \\
\hline $\mathbf{L i}$ & ND & ND & ND & 0.05 & ND & ND \\
\hline $\mathrm{Sr}$ & 0.14 & 0.18 & 0.63 & 2.50 & 0.23 & 0.28 \\
\hline $\mathrm{Zn}$ & ND & ND & ND & ND & $N D$ & ND \\
\hline $\mathrm{Mn}$ & ND & ND & ND & ND & ND & 0.90 \\
\hline $\mathrm{Ni}$ & ND & ND & ND & ND & ND & ND \\
\hline $\mathrm{HCO}_{3}$ & 149.00 & 246.00 & 178.00 & 202.00 & 154.00 & 211.00 \\
\hline $\mathrm{SO}_{4}$ & 35.00 & 12.00 & 99.00 & 636.00 & 62.00 & 76.00 \\
\hline $\mathrm{Cl}^{4}$ & 33.00 & 8.30 & 7.00 & 86.00 & 68.00 & 130.00 \\
\hline $\mathrm{PO}_{4}$ & ND & ND & ND & ND & ND & ND \\
\hline$F^{-4}$ & 0.20 & 0.10 & 0.30 & 0.30 & 0.30 & 0.20 \\
\hline
\end{tabular}




\begin{tabular}{|c|c|c|c|c|c|c|}
\hline $\begin{array}{l}\text { Sample \# } \\
\text { Location } \\
\text { Name/Owner } \\
\text { Reference }\end{array}$ & $\begin{array}{l}\text { W25 } \\
\text { (C-40-13)27bac } \\
\text { J. Telaroli }\end{array}$ & $\begin{array}{l}\text { S26 } \\
(C-42-16) 11 d c b \\
\text { Miller } \\
\text { Spring }\end{array}$ & $\begin{array}{l}\text { W27 } \\
\text { (C-41-17)7dac } \\
\text { St.George City } \\
\text { Gunlock } \# 3\end{array}$ & $\begin{array}{l}\text { W28 } \\
(C-42-16) 22 d c a \\
\text { L. Frye }\end{array}$ & $\begin{array}{l}\text { W29 } \\
\text { (C-41-17)8bca } \\
\text { St.George City } \\
\text { Gunlock \#4 }\end{array}$ & $\begin{array}{l}\text { W30 } \\
\text { (C-42-16)5bbb } \\
\text { W. Hafen }\end{array}$ \\
\hline Date & $02-26-86$ & $02-27-86$ & $02-27-86$ & $02-27-86$ & $02-27-86$ & $02-28-86$ \\
\hline $\operatorname{Temp}\left({ }^{\circ} \mathrm{C}\right)$ & 18.5 & 19.0 & 18.0 & 17.0 & 17.0 & 19.0 \\
\hline pH & 7.8 & 7.9 & 8.0 & 7.4 & 7.6 & 7.2 \\
\hline CalcTDS & 420 & 495 & 303 & 1828 & 311 & 3848 \\
\hline MeasTDS & 430 & 500 & 294 & 1960 & 306 & 4182 \\
\hline $\mathrm{Na}$ & 18.00 & 77.00 & 14.00 & 152.00 & 17.00 & 289.00 \\
\hline $\mathbf{K}$ & 2.00 & 8.00 & 2.00 & 6.00 & 2.00 & 8.00 \\
\hline $\mathrm{Ca}$ & 88.00 & 57.00 & 67.00 & 278.00 & 69.00 & 491.00 \\
\hline Mg & 27.00 & 17.00 & 16.00 & 101.00 & 14.00 & 267.00 \\
\hline $\mathrm{Fe}$ & ND & ND & ND & ND & ND & 0.03 \\
\hline Al & ND & ND & ND & ND & ND & ND \\
\hline $\mathrm{SiO}_{2}$ & 32.00 & 18.00 & 21.00 & 41.00 & 31.00 & 32.00 \\
\hline B $^{2}$ & ND & 0.20 & ND & 0.30 & ND & 1.40 \\
\hline $\mathrm{Li}$ & ND & 0.13 & ND & 0.09 & ND & 0.20 \\
\hline $\mathrm{Sr}$ & 0.33 & 0.59 & 0.39 & 4.57 & 0.29 & 8.71 \\
\hline $\mathrm{Zn}$ & ND & ND & ND & ND & ND & 0.20 \\
\hline Mn & ND & ND & ND & ND & ND & ND \\
\hline $\mathrm{Ni}$ & ND & ND & ND & ND & ND & ND \\
\hline $\mathrm{HCO}_{3}$ & 233.00 & 170.00 & 247.00 & 348.00 & 229.00 & 212.00 \\
\hline $\mathrm{SO}_{4}{ }^{3}$ & 38.00 & 202.00 & 45.00 & 959.00 & 32.00 & 2514.00 \\
\hline $\mathrm{Cl}^{4}$ & 100.00 & 30.00 & 16.00 & 115.00 & 33.00 & 132.00 \\
\hline $\mathrm{PO}_{4}$ & ND & ND & ND & ND & ND & ND \\
\hline$F^{4}$ & 0.20 & 1.10 & 0.30 & 0.40 & 0.20 & 0.60 \\
\hline
\end{tabular}

\begin{tabular}{|c|c|c|c|c|c|c|}
\hline $\begin{array}{l}\text { Sample \# } \\
\text { Location } \\
\text { Name/Owner } \\
\text { Reference }\end{array}$ & $\begin{array}{l}\text { W31 } \\
\text { (C-42-17)1aac } \\
\text { W. Hafen }\end{array}$ & $\begin{array}{l}\text { W32 } \\
(C-41-13) \text { Scdd } \\
\text { L. Lee }\end{array}$ & $\begin{array}{l}\text { W33 } \\
\text { (C-43-15)10eca } \\
\text { O. Gregorson }\end{array}$ & $\begin{array}{l}\text { W34 } \\
\text { (C-42-14)12dbd } \\
\text { E. Graff }\end{array}$ & $\begin{array}{l}\text { W35 } \\
\text { (C-42-13)7cdb } \\
\text { W. Cooper }\end{array}$ & $\begin{array}{l}\text { W36 } \\
\text { (C-42-15)6ddb } \\
\text { St.GeorgeCity } \\
\text { Creek \#2 }\end{array}$ \\
\hline Date & $02-28-86$ & $02-28-86$ & $02-28-86$ & $03-25-86$ & $03-25-86$ & $03-26-86$ \\
\hline $\operatorname{Temp}\left({ }^{\circ} \mathrm{C}\right)$ & 20.0 & 18.0 & 21.0 & 18.0 & 20.0 & 26.0 \\
\hline pH & 8.0 & 7.7 & 7.1 & 7.9 & 7.7 & 7.0 \\
\hline CalcTDS & 3081 & 450 & 4109 & 259 & 353 & 928 \\
\hline MeasTDS & 3140 & 425 & 4398 & 267 & 382 & 952 \\
\hline $\mathrm{Na}$ & 847.00 & 32.00 & 484.00 & 17.00 & 37.00 & 176.00 \\
\hline $\mathbf{K}$ & 21.00 & 2.00 & 7.00 & 2.00 & 2.00 & 19.00 \\
\hline $\mathrm{Ca}$ & 79.00 & 74.00 & 637.00 & 37.00 & 46.00 & 90.00 \\
\hline $\mathbf{M g}$ & 47.00 & 31.00 & 154.00 & 23.00 & 27.00 & 18.00 \\
\hline $\mathrm{Fe}$ & 0.15 & ND & ND & ND & ND & 0.06 \\
\hline Al & ND & ND & ND & ND & ND & ND \\
\hline $\mathrm{SiO}_{2}$ & 9.00 & 36.00 & 25.00 & 14.00 & 15.00 & 20.00 \\
\hline $\mathrm{B}^{2}$ & 0.90 & ND & 0.70 & 0.20 & ND & 0.50 \\
\hline $\mathbf{L i}$ & 0.14 & ND & 0.39 & ND & ND & 0.21 \\
\hline $\mathrm{Sr}$ & 1.61 & 0.51 & 8.96 & 0.20 & 0.38 & 1.35 \\
\hline $\mathrm{Zn}$ & ND & ND & ND & ND & ND & ND \\
\hline Mn & ND & ND & ND & ND & ND & ND \\
\hline $\mathrm{Ni}$ & ND & ND & ND & ND & ND & ND \\
\hline $\mathrm{HCO}_{3}$ & 536.00 & 312.00 & 341.00 & 141.00 & 154.00 & 197.00 \\
\hline $\mathrm{SO}_{4}$ & 1640.00 & 65.00 & 1930.00 & 43.00 & 106.00 & 462.00 \\
\hline $\mathrm{Cl}^{4}$ & 170.00 & 56.00 & 694.00 & 41.00 & 44.00 & 41.00 \\
\hline $\mathrm{PO}_{4}$ & ND & ND & ND & ND & ND & ND \\
\hline$F^{-}$ & 1.50 & 0.30 & 0.30 & 0.20 & 0.30 & 2.70 \\
\hline
\end{tabular}




\begin{tabular}{|c|c|c|c|c|c|c|}
\hline $\begin{array}{l}\text { Sample \# } \\
\text { Location } \\
\text { Name/Owner } \\
\text { Reference }\end{array}$ & $\begin{array}{l}\text { W37 } \\
\text { (C-42-16)24bdd } \\
\text { St. George City } \\
\text { Bluff Park }\end{array}$ & $\begin{array}{l}\text { W38 } \\
\text { (C-42-16)25aab } \\
\text { G. Johnson }\end{array}$ & $\begin{array}{l}\text { W39 } \\
\text { (C-42-16)26bcb } \\
\text { R. Mathis }\end{array}$ & $\begin{array}{l}\text { W } 40 \\
\text { (C-43-15)12ced } \\
\text { Stucki Farms }\end{array}$ & $\begin{array}{l}\text { W41 } \\
\text { (C-43-15)12cec } \\
\text { Stucki Farms }\end{array}$ & $\begin{array}{l}\text { W42 } \\
\text { (C-43-15)25ddd } \\
\text { LDS Church } \\
\text { Farm }\end{array}$ \\
\hline Date & $03-27-86$ & $03-27-86$ & $03-27-86$ & $03-24-86$ & $03-24-86$ & $03-24-86$ \\
\hline $\operatorname{Temp}\left({ }^{\circ} \mathrm{C}\right)$ & 18.0 & 19.0 & 17.5 & 18.5 & 21.5 & 18.0 \\
\hline $\mathrm{pH}$ & 7.7 & 7.0 & 7.2 & 7.1 & 7.8 & 7.1 \\
\hline CalcTDS & 3002 & 1856 & 2861 & 3025 & 2492 & 3432 \\
\hline MeasTDS & 3226 & 1940 & 3096 & 3226 & 2646 & 3758 \\
\hline $\mathrm{Na}$ & 271.00 & 261.00 & 218.00 & 321.00 & 501.00 & 173.00 \\
\hline $\mathbf{K}$ & 17.00 & 45.00 & 11.00 & 8.00 & 12.00 & 14.00 \\
\hline $\mathrm{Ca}$ & 470.00 & 220.00 & 425.00 & 380.00 & 155.00 & 598.00 \\
\hline $\mathrm{Mg}$ & 123.00 & 70.00 & 183.00 & 200.00 & 125.00 & 192.00 \\
\hline $\mathrm{Fe}$ & ND & ND & 1.34 & ND & ND & ND \\
\hline $\mathrm{Al}$ & ND & ND & ND & ND & ND & ND \\
\hline $\mathrm{SiO}_{2}$ & 17.00 & 24.00 & 37.00 & 22.00 & 17.00 & 18.00 \\
\hline $\mathrm{B}^{2}$ & 0.70 & 0.60 & 0.60 & 0.60 & 0.60 & 0.50 \\
\hline $\mathrm{Li}$ & 0.26 & 0.25 & 0.14 & 0.21 & 0.15 & ND \\
\hline Sr & 6.31 & 1.90 & 7.07 & 7.96 & 4.16 & 9.73 \\
\hline $\mathrm{Zn}$ & ND & ND & ND & ND & ND & ND \\
\hline Mn & ND & ND & ND & ND & ND & ND \\
\hline $\mathrm{Ni}$ & ND & ND & ND & ND & ND & ND \\
\hline $\mathrm{HCO}_{3}$ & 253.00 & 378.00 & 501.00 & 243.00 & 167.00 & 149.00 \\
\hline $\mathrm{SO}_{4}{ }^{3}$ & 1886.00 & 970.00 & 1608.00 & 1439.00 & 1164.00 & 2216.00 \\
\hline $\mathrm{Cl}^{4}$ & 85.00 & 76.00 & 123.00 & 526.00 & 430.00 & 138.00 \\
\hline $\mathrm{PO}_{4}$ & ND & ND & ND & ND & ND & ND \\
\hline$F^{4}$ & 1.70 & 1.00 & 0.60 & 0.60 & 0.90 & 0.20 \\
\hline
\end{tabular}

\begin{tabular}{|c|c|c|c|c|c|c|}
\hline $\begin{array}{l}\text { Sample \# } \\
\text { Location } \\
\text { Name/Owner } \\
\text { Reference }\end{array}$ & $\begin{array}{l}\text { W43 } \\
(C-42-16) 13 \mathrm{ced} \\
\text { J\&J Lumber Co. }\end{array}$ & $\begin{array}{l}\text { S44 } \\
\text { (C-41-16)34bda } \\
\text { Snow Spring }\end{array}$ & $\begin{array}{l}\text { W45 } \\
\text { (C-43-15)16ede } \\
\text { J\&J Lumber Co. }\end{array}$ & $\begin{array}{l}\text { W46 } \\
(C-42-17) 1 b d a \\
\text { F. Lnce }\end{array}$ & $\begin{array}{l}\text { W47 } \\
\text { (C-42-15)29bea } \\
\text { Dixie College }\end{array}$ & $\begin{array}{l}\text { W } 48 \\
\text { (C-42-15)23cba } \\
\text { L. Sorden }\end{array}$ \\
\hline Date & $03-25-86$ & $03-25-86$ & $03-25-86$ & $03-26-86$ & $03-27-86$ & $03-27-86$ \\
\hline $\operatorname{Temp}\left({ }^{\circ} \mathrm{C}\right)$ & 15.0 & 19.0 & 18.0 & 16.0 & 18.5 & 15.0 \\
\hline $\mathrm{pH}$ & 7.7 & 8.3 & 7.1 & 7.6 & 7.2 & 7.5 \\
\hline CalcTDS & 369 & 210 & 3239 & 639 & 2995 & 1141 \\
\hline MeasTDS & 362 & 226 & 3480 & 682 & 3262 & 1210 \\
\hline $\mathrm{Na}$ & 15.00 & 13.00 & 239.00 & 58.00 & 285.00 & 172.00 \\
\hline $\mathbf{K}$ & 2.00 & 3.00 & 19.0 & 4.00 & 26.00 & 21.00 \\
\hline $\mathrm{Ca}$ & 80.00 & 35.00 & 654.00 & 102.00 & 433.00 & 129.00 \\
\hline $\mathrm{Mg}$ & 18.00 & 12.00 & 89.00 & 35.00 & 138.00 & 51.00 \\
\hline $\mathrm{Fe}$ & ND & 0.03 & ND & ND & 0.38 & ND \\
\hline $\mathrm{Al}$ & ND & ND & ND & ND & ND & ND \\
\hline $\mathrm{SiO}_{2}$ & 24.00 & 14.00 & 20.00 & 29.00 & 20.00 & 29.00 \\
\hline $\mathrm{B}^{2}$ & ND & 0.20 & 0.40 & 0.20 & 1.00 & 0.30 \\
\hline $\mathrm{Li}$ & ND & 0.09 & 0.05 & ND & 0.39 & 0.19 \\
\hline Sr & 0.39 & 0.41 & 8.00 & 0.95 & 6.63 & 1.81 \\
\hline $\mathrm{Zn}$ & ND & ND & ND & ND & ND & ND \\
\hline Mn & ND & ND & ND & ND & ND & ND \\
\hline $\mathrm{Ni}$ & ND & ND & ND & ND & ND & ND \\
\hline $\mathrm{HCO}_{3}$ & 238.00 & 117.00 & 254.00 & 315.00 & 287.00 & 359.00 \\
\hline $\mathrm{SO}_{4}$ & 77.00 & 59.00 & 1651.00 & 212.00 & 1857.00 & 395.00 \\
\hline $\mathrm{Cl}^{4}$ & 35.00 & 15.00 & 433.00 & 43.00 & 86.00 & 164.00 \\
\hline $\mathrm{PO}_{4}$ & ND & ND & ND & ND & ND & ND \\
\hline$F^{4}$ & 0.30 & 0.70 & 0.20 & 0.30 & 0.30 & 0.90 \\
\hline
\end{tabular}




\begin{tabular}{|c|c|c|c|c|c|c|}
\hline $\begin{array}{l}\text { Sample \# } \\
\text { Location } \\
\text { Name/Owner } \\
\text { Reference }\end{array}$ & $\begin{array}{l}\text { W49 } \\
\text { (C-42-15)33cbc } \\
\text { P. Foremaster }\end{array}$ & $\begin{array}{l}\text { WSO } \\
\text { (C-42-15)26ddd } \\
\text { E. Harmon }\end{array}$ & $\begin{array}{l}\text { S51 } \\
\text { (C-40-14)8cab } \\
\text { Columbine Spg. }\end{array}$ & $\begin{array}{l}\text { W52 } \\
\text { (C-43-16)14ddb } \\
\text { G. Kemp }\end{array}$ & $\begin{array}{l}\text { W53 } \\
\text { (C-42-15)21bca } \\
\text { N. Howard }\end{array}$ & $\begin{array}{l}\text { W54 } \\
\text { (C-43-15)23add } \\
\text { L. Hancock }\end{array}$ \\
\hline Date & $03-27-86$ & $03-27-86$ & $03-27-86$ & $03-27-86$ & $03-28-86$ & $03-28-86$ \\
\hline Temp $\left({ }^{\circ} \mathrm{C}\right)$ & 24.5 & 18.00 & 10.0 & 19.0 & 17.0 & 19.0 \\
\hline $\mathrm{pH}$ & 6.6 & 7.0 & 7.7 & 7.0 & 7.3 & 7.5 \\
\hline CalcTDS & 2588 & 2183 & 228 & 3419 & 1042 & 3220 \\
\hline MeasTDS & 2740 & 2336 & 236 & 3690 & 1063 & 3456 \\
\hline $\mathrm{Na}$ & 442.00 & 310.00 & 5.70 & 429.00 & 187.00 & 157.00 \\
\hline $\mathbf{K}$ & 19.00 & 12.00 & ND & 18.00 & 19.00 & 9.00 \\
\hline $\mathrm{Ca}$ & 260.00 & 294.00 & 62.00 & 417.00 & 97.00 & 585.00 \\
\hline $\mathbf{M g}$ & 102.00 & 99.00 & 8.00 & 171.00 & 26.00 & 188.00 \\
\hline $\mathrm{Fe}$ & 0.38 & ND & 0.08 & 9.39 & ND & ND \\
\hline $\mathrm{Al}$ & ND & ND & ND & ND & ND & ND \\
\hline $\mathrm{SiO}_{2}$ & 16.00 & 22.00 & 27.00 & 18.00 & 18.20 & 21.00 \\
\hline $\mathrm{B}^{2}$ & 0.70 & 0.60 & ND & 0.90 & 0.41 & 0.30 \\
\hline $\mathrm{Li}$ & 0.28 & 0.31 & ND & 0.34 & 0.22 & 0.06 \\
\hline $\mathrm{Sr}$ & 3.70 & 3.97 & 0.10 & 6.63 & 1.63 & 9.48 \\
\hline $\mathrm{Zn}$ & ND & ND & ND & ND & ND & ND \\
\hline Mn & ND & ND & ND & ND & ND & ND \\
\hline $\mathrm{Ni}$ & 0.40 & ND & ND & ND & ND & ND \\
\hline $\mathrm{HCO}_{3}$ & 380.00 & 353.00 & 248.00 & 222.00 & 235.00 & 116.00 \\
\hline $\mathrm{SO}_{4}{ }^{3}$ & 1138.00 & 900.00 & 3.00 & 1816.00 & 512.00 & 1966.00 \\
\hline $\mathrm{Cl}^{*}$ & 416.00 & 367.00 & ND & 423.00 & 63.00 & 227.00 \\
\hline $\mathrm{PO}_{4}$ & ND & ND & ND & ND & ND & ND \\
\hline$F^{4}$ & 2.30 & 0.30 & ND & 0.50 & 1.90 & 0.40 \\
\hline
\end{tabular}

\begin{tabular}{|c|c|c|c|c|c|c|}
\hline $\begin{array}{l}\text { Sample \# } \\
\text { Location } \\
\text { Name/O wner } \\
\text { Reference } \\
\end{array}$ & $\begin{array}{l}\text { W55 } \\
\text { (C-43-15)2aan } \\
\text { G. Andrus }\end{array}$ & $\begin{array}{l}\text { S56 } \\
\text { (C-40-16)6edb } \\
\text { Veyo Hot } \\
\text { Spring } \\
\text { Mundorf, } 1970\end{array}$ & $\begin{array}{l}\text { S57 } \\
\text { (C-41-13)25cbe } \\
\text { Pah Tempe } \\
\text { Hot Springs } \\
\text { Mundorf, } 1970\end{array}$ & $\begin{array}{l}\text { S58 } \\
(C-42-15) 16 d d d \\
\text { Huntington } \\
\text { Cordova, } 1978\end{array}$ & $\begin{array}{l}\text { S59 } \\
(C-42-15) 19 \mathrm{cba} \\
\text { Cox } \\
\text { Cordova, } 1978\end{array}$ & $\begin{array}{l}\text { S60 } \\
\text { (C-42-16)13dcb } \\
\text { WestSt.George } \\
\text { Spring } \\
\text { Cordova, } 1978 \\
\end{array}$ \\
\hline Date & $03-28-86$ & $04-20-67$ & $03-25-66$ & $01-18-74$ & $11-18-74$ & $01-21-74$ \\
\hline $\operatorname{Temp}\left({ }^{\circ} \mathrm{C}\right)$ & 19.00 & 32.0 & 42.0 & 20.0 & 19.0 & 20.0 \\
\hline pH & 7.1 & 7.6 & 7.2 & 8.0 & 7.1 & 8.1 \\
\hline CalcTDS & 4330 & 383 & 9523 & 1045 & 821 & 693 \\
\hline MeasTDS & 4688 & - & - & 1050 & 823 & 697 \\
\hline $\mathrm{Na}$ & 416.00 & 32.00 & 2530.00 & 190.00 & 130.00 & 120.00 \\
\hline $\mathbf{K}$ & 11.30 & 3.60 & 220.00 & 18.00 & 13.00 & 10.00 \\
\hline $\mathrm{Ca}$ & 573.00 & 53.00 & 643.00 & 110.00 & 93.00 & 78.00 \\
\hline $\mathbf{M g}$ & 293.00 & 28.00 & 128.00 & 26.00 & 28.00 & 23.00 \\
\hline $\mathrm{Fe}$ & ND & 0.01 & 0.01 & 0.03 & 0.04 & 0.04 \\
\hline Al & ND & ND & 0.10 & ND & ND & ND \\
\hline $\mathrm{SiO}_{2}$ & 21.00 & 32.00 & 28.00 & 20.00 & 17.00 & 17.00 \\
\hline B & 0.67 & 0.14 & 4.80 & 0.55 & 0.45 & 0.47 \\
\hline $\mathrm{Li}$ & 0.14 & 0.02 & 2.00 & ND & ND & ND \\
\hline $\mathrm{Sr}$ & 10.15 & ND & ND & ND & ND & ND \\
\hline $\mathrm{Zn}$ & ND & ND & .002 & ND & ND & ND \\
\hline Mn & ND & ND & ND & ND & ND & ND \\
\hline $\mathrm{Ni}$ & ND & ND & ND & ND & 0.05 & ND \\
\hline $\mathrm{HCO}_{3}$ & 253.00 & 230.00 & 721.00 & 249.00 & 202.00 & 191.00 \\
\hline $\mathrm{SO}_{4}$ & 2251.00 & 90.00 & 1990.00 & 460.00 & 400.00 & 320.00 \\
\hline $\mathrm{Cl}^{*}$ & 629.00 & 30.00 & 3620.00 & 96.00 & 39.00 & 30.00 \\
\hline $\mathrm{PO}_{4}$ & ND & ND & ND & ND & ND & ND \\
\hline$F^{4}$ & 0.60 & 0.70 & 2.60 & 1.50 & 0.80 & 0.60 \\
\hline
\end{tabular}




\begin{tabular}{|c|c|c|c|c|c|c|}
\hline $\begin{array}{l}\text { Sample \# } \\
\text { Location } \\
\text { Name/Owner } \\
\text { Reference }\end{array}$ & $\begin{array}{l}\text { W61 } \\
\text { (C-41-13)16bed } \\
\text { Utah State } \\
\text { Land Board } \\
\text { Goode, } 1978\end{array}$ & $\begin{array}{l}\text { W62 } \\
\text { (C-42-16)22dca } \\
\text { L. Frei } \\
\text { Goode, } 1978\end{array}$ & $\begin{array}{l}\text { W63 } \\
\text { (C-43-15)12ecd } \\
\text { S. Stucki } \\
\text { Goode, } 1978\end{array}$ & $\begin{array}{l}\text { W64 } \\
\text { (C-41-13)4bbe } \\
\text { H. Ludwig } \\
\text { Cordova, } 1978\end{array}$ & $\begin{array}{l}\text { W65 } \\
\text { (C-41-13)5aaa } \\
\text { E. Wooten } \\
\text { Cordova, } 1978\end{array}$ & $\begin{array}{l}\text { W66 } \\
\text { (C-41-13)5bbc } \\
\text { Goddard } \\
\text { Cordova, } 1978\end{array}$ \\
\hline Date & $03-05-70$ & $05-19-67$ & $05-19-67$ & $01-10-75$ & $07-05-74$ & $07-03-74$ \\
\hline Temp $\left({ }^{\circ} \mathrm{C}\right)$ & 21.5 & 16.5 & 19.0 & 11.0 & 17.0 & 18.5 \\
\hline pH & 8.0 & 7.7 & 7.8 & 7.7 & 7.8 & 7.6 \\
\hline CalcTDS & 861 & 1445 & 3011 & 317 & 418 & 436 \\
\hline MeasTDS & - & - & - & 325 & - & - \\
\hline $\mathrm{Na}$ & 103.00 & 148.00 & 196.00 & 26.00 & 42.00 & 29.00 \\
\hline $\mathbf{K}$ & 4.50 & 5.00 & 10.00 & 3.30 & 1.50 & 2.30 \\
\hline $\mathrm{Ca}$ & 96.00 & 204.00 & 417.00 & 54.00 & 78.00 & 80.00 \\
\hline $\mathbf{M g}$ & 60.00 & 83.00 & 209.00 & 21.00 & 19.00 & 29.00 \\
\hline $\mathrm{Fe}$ & ND & ND & ND & ND & 0.01 & 0.03 \\
\hline Al & ND & ND & ND & ND & ND & ND \\
\hline $\mathrm{SiO}_{2}$ & 24.00 & 33.00 & 18.00 & 36.00 & 32.00 & 24.00 \\
\hline B & 0.56 & ND & ND & 0.01 & 0.09 & 0.01 \\
\hline $\mathbf{L i}$ & ND & ND & ND & ND & ND & ND \\
\hline Sr. & 10.15 & ND & ND & ND & ND & ND \\
\hline$Z_{n}$ & ND & ND & ND & ND & ND & ND \\
\hline $\mathrm{Mn}$ & ND & ND & ND & ND & ND & 0.01 \\
\hline $\mathrm{Ni}$ & ND & ND & ND & ND & ND & ND \\
\hline $\mathrm{HCO}_{3}$ & 250.00 & 352.00 & 100.00 & 257.00 & 212.00 & 248.00 \\
\hline $\mathrm{SO}_{4}{ }^{3}$ & 375.00 & 706.00 & 2050.00 & 31.00 & 43.00 & 110.00 \\
\hline $\mathrm{Cl}^{4}$ & 74.00 & 92.00 & 72.00 & 19.00 & 98.00 & 39.00 \\
\hline $\mathrm{PO}_{4}$ & ND & ND & ND & 0.39 & 0.10 & 0.20 \\
\hline$F^{4}$ & 0.70 & 1.10 & ND & 0.20 & 0.20 & 0.20 \\
\hline
\end{tabular}

\begin{tabular}{|c|c|c|c|c|c|c|}
\hline $\begin{array}{l}\text { Sample \# } \\
\text { Location } \\
\text { Name/Owner } \\
\text { Reference }\end{array}$ & $\begin{array}{l}\text { W67 } \\
\text { (C-41-13)23bea } \\
\text { Ash Creek } \\
\text { Cordova, } 1978\end{array}$ & $\begin{array}{l}\text { W68 } \\
(C-41-15) 32 a c a \\
\text { Terracor } \\
\text { Cordova, } 1978\end{array}$ & $\begin{array}{l}\text { W69 } \\
\text { (C-41-16)16ebd } \\
\text { St. George City } \\
\text { Snow Cyn. \#1 } \\
\text { Cordova, 1978 }\end{array}$ & $\begin{array}{l}\text { W70 } \\
(C-42-13) 7 b b a \\
\text { W. Wilson } \\
\text { Condova, } 1978\end{array}$ & $\begin{array}{l}\text { W71 } \\
\text { (C-42-14)12ada } \\
\text { W. Wilson } \\
\text { Cordova, } 1978\end{array}$ & $\begin{array}{l}\text { W72 } \\
\text { (C-42-14)12dda } \\
\text { W. Wilson } \\
\text { Cordova, } 1978 \\
\end{array}$ \\
\hline Date & $02-05-75$ & $11-15-74$ & $07-19-74$ & $11-17-74$ & $10-23-74$ & $05-21-74$ \\
\hline $\operatorname{Temp}\left({ }^{\circ} \mathrm{C}\right)$ & 17.5 & 40.0 & 20.0 & 21.5 & 19.5 & 19.0 \\
\hline $\mathrm{pH}$ & 7.4 & 7.3 & 8.2 & 7.5 & 7.8 & 7.9 \\
\hline CalcTDS & 1317 & 1361 & 106 & 910 & 186 & 169 \\
\hline MeasTDS & 1340 & 1360 & - & 916 & 193 & 181 \\
\hline $\mathrm{Na}$ & 64.00 & 340.00 & 4.00 & 90.00 & 10.00 & 6.10 \\
\hline $\mathbf{K}$ & 6.00 & 29.00 & 1.80 & 5.20 & 1.70 & 1.70 \\
\hline $\mathrm{Ca}$ & 180.00 & 110.00 & 21.00 & 140.00 & 32.00 & 33.00 \\
\hline Mg & 110.00 & 19.00 & 6.40 & 48.00 & 16.00 & 17.00 \\
\hline $\mathrm{Fe}$ & ND & ND & ND & ND & ND & ND \\
\hline Al & ND & ND & ND & ND & ND & ND \\
\hline $\mathrm{SiO}_{2}$ & 26.00 & 20.00 & 18.00 & 18.00 & 15.00 & 15.00 \\
\hline B $^{2}$ & 0.58 & 0.17 & ND & 0.21 & 0.05 & ND \\
\hline $\mathrm{Li}$ & ND & ND & ND & ND & ND & ND \\
\hline $\mathrm{Sr}$ & ND & ND & ND & ND & ND & ND \\
\hline $\mathrm{Zn}$ & ND & ND & ND & ND & ND & ND \\
\hline $\mathrm{Mn}$ & ND & ND & ND & ND & ND & ND \\
\hline $\mathrm{Ni}$ & ND & ND & ND & ND & ND & ND \\
\hline $\mathrm{HCO}_{3}$ & 216.00 & 226.00 & 81.00 & 147.00 & 112.00 & 137.00 \\
\hline $\mathrm{SO}_{4}$ & 750.00 & 350.00 & 9.90 & 440.00 & 49.00 & 15.00 \\
\hline $\mathrm{Cl}^{4}$ & 74.00 & 380.00 & 5.20 & 96.00 & 6.30 & 14.00 \\
\hline $\mathrm{PO}_{4}$ & 0.01 & 0.01 & 0.29 & 0.01 & 0.01 & 0.01 \\
\hline$F^{4}$ & 0.60 & 1.30 & 0.20 & 0.30 & 0.50 & 0.20 \\
\hline
\end{tabular}




\begin{tabular}{|c|c|c|c|c|c|}
\hline $\begin{array}{l}\text { Sample \# } \\
\text { Location } \\
\text { Name/Owner } \\
\text { Reference }\end{array}$ & $\begin{array}{l}\text { W73 } \\
\text { (C-42-14)25abb } \\
\text { Terracor \#3 } \\
\text { Cordova, } 1978\end{array}$ & $\begin{array}{l}\text { W74 } \\
\text { (C-42-15)6dcc } \\
\text { St. George City } \\
\text { Creek \#1 } \\
\text { Cordova, } 1978\end{array}$ & $\begin{array}{l}\text { W75 } \\
\text { (C-42-15)6ded } \\
\text { St. George City } \\
\text { Creek \#2 } \\
\text { Cordova, } 1978\end{array}$ & $\begin{array}{l}\text { W76 } \\
\text { (C-42-15)10bed } \\
\text { Washington } \\
\text { City } \\
\text { Cordova, } 1978\end{array}$ & $\begin{array}{l}\text { W77 } \\
\text { (C-41-13)7ceb } \\
\text { L. Sullivan } \\
\text { Cordova } \\
\text { and others, } 1978\end{array}$ \\
\hline Date & $03-19-75$ & $02-14-73$ & $09-18-74$ & $05-18-74$ & $05-05-70$ \\
\hline Temp $\left({ }^{\circ} \mathrm{C}\right)$ & 18.5 & 26.0 & 26.0 & 29.0 & 13.5 \\
\hline pH & 7.7 & 7.1 & 7.0 & 7.1 & 7.9 \\
\hline CalcTDS & 187 & 968 & 960 & 1251 & 478 \\
\hline MeasTDS & 256 & 968 & 962 & 1250 & 497 \\
\hline $\mathrm{Na}$ & 11.00 & 170.00 & 170.00 & 290.00 & 16.00 \\
\hline K & 2.30 & 20.00 & 20.00 & 26.00 & 2.10 \\
\hline $\mathrm{Ca}$ & 31.00 & 100.00 & 96.00 & 100.00 & 68.00 \\
\hline $\mathrm{Mg}$ & 18.00 & 17.00 & 19.00 & 22.00 & 65.00 \\
\hline $\mathrm{Fe}$ & 0.10 & 0.08 & ND & ND & ND \\
\hline Al & ND & ND & ND & ND & ND \\
\hline $\mathrm{SiO}_{2}$ & 4.40 & 19.00 & 19.00 & 22.00 & 45.00 \\
\hline $\mathrm{B}^{2}$ & ND & 0.72 & 0.67 & 0.52 & 0.30 \\
\hline $\mathbf{L i}$ & ND & ND & ND & ND & ND \\
\hline $\mathrm{Sr}$ & ND & ND & ND & ND & ND \\
\hline $\mathrm{Zn}$ & ND & ND & ND & ND & ND \\
\hline $\mathrm{Mn}$ & ND & ND & ND & ND & ND \\
\hline $\mathrm{Ni}$ & ND & ND & ND & ND & ND \\
\hline $\mathrm{HCO}_{3}$ & 143.00 & 197.00 & 200.00 & 222.00 & 522.00 \\
\hline $\mathrm{SO}_{4}$ & 34.00 & 500.00 & 490.00 & 330.00 & 14.00 \\
\hline $\mathrm{Cl}^{4}$ & 16.00 & 41.00 & 45.00 & 350.00 & 10.00 \\
\hline $\mathrm{PO}_{4}$ & 0.06 & 0.01 & 0.01 & 0.01 & ND \\
\hline$F^{4}$ & 0.02 & 2.40 & 2.40 & 1.10 & 0.40 \\
\hline
\end{tabular}

Table 2. Calculated chemical geothermometer temperatures and surface temperatures (in ${ }^{\circ} \mathrm{C}$ ) for spring and well water samples in the St. George basin. Dash (-) indicates $\mathrm{K}$ belor detection limit so Na-K-Ca geothermometer cannot be completed; NA indicates Na-K-Ca temperature is less than $70^{\circ} \mathrm{C}$ so the $\mathrm{Mg}$ correction does not apply.

\begin{tabular}{|c|c|c|c|c|c|}
\hline Sample & $\begin{array}{c}\text { Measured } \\
\text { Temperature }\end{array}$ & $\begin{array}{c}\text { Quartz } \\
\text { (Conduetive) }\end{array}$ & Chalcedony & $\mathrm{Na}-\mathrm{K}-\mathrm{Ca}$ & $\begin{array}{r}\text { Na-K-C } \\
(\mathbf{M g} \text {-correc }\end{array}$ \\
\hline $\mathbf{S i}$ & 18.5 & 73 & 41 & - & - \\
\hline S2 (Veyo HS) & 29.5 & 90 & 59 & 38 & NA \\
\hline S3 & 23 & 67 & 35 & 168 & 71 \\
\hline S4 & 16.5 & 96 & 65 & 23 & NA \\
\hline S5 (Pah Tempe HS) & 42 & 75 & 44 & 173 & 83 \\
\hline S6 & 16.5 & 97 & 67 & 22 & NA \\
\hline S7 & 18.5 & 74 & 42 & 54 & NA \\
\hline S8 (Washington hot pot) & 24.5 & 60 & 27 & 21 & NA \\
\hline W9 & 9 & 109 & 79 & 27 & NA \\
\hline W10 & 12 & 95 & 64 & 18 & NA \\
\hline W11 & 19 & 63 & 31 & 77 & 66 \\
\hline W12 & 18 & 45 & 13 & 21 & NA \\
\hline$S 13$ & 9 & 105 & 75 & 14 & NA \\
\hline W14 & 16 & 109 & 79 & 50 & NA \\
\hline S15 & 15 & 57 & 25 & 33 & NA \\
\hline W16 & 26.5 & 72 & 40 & 26 & NA \\
\hline W17 & 20 & 53 & 21 & 24 & NA \\
\hline W18 & 17 & 63 & 31 & 35 & NA \\
\hline W19 & 18.5 & 51 & 18 & 30 & NA \\
\hline $\mathbf{S} 20$ & 7 & 75 & 44 & - & - \\
\hline W21 & 12 & 55 & 23 & 9 & NA \\
\hline W22 & 21 & 69 & 37 & 46 & NA \\
\hline W23 & 20 & 53 & 21 & - & -- \\
\hline W24 & 17.5 & 85 & 54 & - & -- \\
\hline W25 & 18.5 & 82 & 85 & 11 & NA \\
\hline$S 26$ & 19 & 60 & 27 & 66 & NA \\
\hline
\end{tabular}




\begin{tabular}{|c|c|c|c|c|c|}
\hline Sample & $\begin{array}{c}\text { Measured } \\
\text { Temperature }\end{array}$ & $\begin{array}{c}\text { Quartz } \\
\text { (Conductive) }\end{array}$ & Chalcedony & $\mathrm{Na}-\mathrm{K}-\mathrm{Ca}$ & $\begin{array}{c}\mathrm{Na}-\mathrm{K}-\mathrm{Ca} \\
\text { (Mg-corrected) }\end{array}$ \\
\hline W27 & 18 & 65 & 33 & 13 & NA \\
\hline W28 & 17 & 93 & 62 & 35 & NA \\
\hline W29 & 17 & 81 & 49 & 14 & NA \\
\hline W30 & 19 & 82 & 51 & 38 & NA \\
\hline W31 & 20 & 36 & 3 & 128 & 25 \\
\hline W32 & 18 & 87 & 56 & 18 & NA \\
\hline W33 & 21 & 72 & 40 & 35 & NA \\
\hline W34 & 18 & 51 & 18 & 24 & NA \\
\hline W35 & 20 & 53 & 21 & 26 & NA \\
\hline W36 & 26 & 63 & 31 & 93 & 80 \\
\hline W37 & 18 & 57 & 25 & 59 & NA \\
\hline W38 & 19 & 70 & 39 & 197 & 51 \\
\hline W39 & 17.5 & 88 & 57 & 47 & NA \\
\hline W40 & 18.5 & 67 & 35 & 44 & NA \\
\hline W41 & 21.5 & 57 & 25 & 77 & NA \\
\hline W42 & 18 & 60 & 27 & 45 & NA \\
\hline W43 & 15 & 70 & 39 & 11 & NA \\
\hline S44 & 19 & 51 & 18 & 32 & NA \\
\hline W45 & 18 & 63 & 31 & 55 & NA \\
\hline W46 & 16 & 78 & 47 & 34 & NA \\
\hline W47 & 18.5 & 63 & 31 & 74 & 62 \\
\hline W48 & 15 & 78 & 47 & 88 & 49 \\
\hline W49 & 24.5 & 55 & 23 & 80 & 51 \\
\hline W50 & 18 & 67 & 35 & 59 & NA \\
\hline $\mathbf{5} 51$ & 10 & 75 & 44 & - & - \\
\hline W52 & 19 & 60 & 27 & 68 & NA \\
\hline W53 & 17 & 60 & 28 & 92 & 66 \\
\hline W54 & 19 & 65 & 33 & 33 & NA \\
\hline W55 & 19 & 65 & 33 & 48 & NA \\
\hline S56 (Veyo HS) & 32 & 82 & 51 & 37 & NA \\
\hline S57(Pah Tempe HS) & 42 & 77 & 45 & 191 & 83 \\
\hline S58 & 20 & 63 & 31 & 88 & 73 \\
\hline $\mathbf{5 5 9}$ & 19 & 57 & 25 & 77 & 66 \\
\hline S60 & 20 & 57 & 25 & 71 & 69 \\
\hline W61 & 21.5 & 70 & 39 & 43 & NA \\
\hline W62 & 16.5 & 83 & 52 & 36 & NA \\
\hline W63 & 19 & 60 & 27 & 44 & NA \\
\hline W64 & 11 & 87 & 56 & 33 & NA \\
\hline W65 & 17 & 82 & 51 & 13 & NA \\
\hline W66 & 18.5 & 70 & 39 & 19 & NA \\
\hline W67 & 17.5 & 74 & 42 & 35 & NA \\
\hline W68 & 40 & 63 & 31 & 169 & 86 \\
\hline W69 & 20 & 60 & 27 & 19 & NA \\
\hline w70 & 21.5 & 60 & 27 & 39 & NA \\
\hline W71 & 19.5 & 53 & 21 & 18 & NA \\
\hline W72 & 19 & 53 & 21 & 14 & NA \\
\hline w73 & 18.5 & 15 & -18 & 26 & NA \\
\hline W74 & 26 & 62 & 29 & 92 & 87 \\
\hline W75 & 26 & 62 & 29 & 93 & 80 \\
\hline W76 & 29 & 67 & 35 & 170 & 71 \\
\hline W77 & 13.5 & 97 & 67 & 15 & NA \\
\hline
\end{tabular}

Table 3. Geothermal gradient data from St. George basin. Conversions: $1 \mathrm{~m}=3.2$ feet; $18.23^{\circ} \mathrm{C} / \mathrm{km}=1^{\circ} \mathrm{F} / 100$ feet.

\begin{tabular}{|c|c|c|c|c|}
\hline Well & Location & $\begin{array}{c}\text { Site } \\
\text { Elevation (m) } \\
\end{array}$ & $\begin{array}{l}\text { Depth Interval } \\
\text { for Calculated } \\
\text { Gradient (m) }\end{array}$ & $\begin{array}{c}\text { Calculated } \\
\text { Gradient }{ }^{\circ} \mathrm{C} / \mathrm{km}\end{array}$ \\
\hline TG1 & $(C-43-15) 16 \mathrm{dcc}$ & 818 & $25-45.3$ & $23.9 \pm 0.2$ \\
\hline TG3 & $(C-43-15) 11$ ddd & 845 & $80.7-125.7$ & $21.8 \pm 0.4$ \\
\hline TG5 & $(C-43-15) 24 d c c$ & 875 & $88.9-133.9$ & $22.3 \pm 0.4$ \\
\hline TG7 & $(C-43-14) 17 \mathrm{cdd}$ & 925 & $43.9-161.9$ & $19.3 \pm 0.7$ \\
\hline TG8 & $(C-42-13) 33 \mathrm{aad}$ & 1035 & $139-161$ & $18.5 \pm 0.2$ \\
\hline TG12 & $(C-42-14) 15 \mathrm{dbd}$ & 895 & $19.5-27$ & $33.7 \pm 0.2$ \\
\hline
\end{tabular}


Table 4. Temperature-depth profile data for TG-1 through TG-16 and TG-18, St. George basin.

Well: TG-1

Location: (C-43-15) 16dcc

Site Elevation: $818 \mathrm{~m}$

Depth Interval for Calculated Gradient: $25-45.3 \mathrm{~m}$

Calculated Gradient: $23.9 \pm 0.2^{\circ} \mathrm{C} / \mathbf{k m}$

Ambient Temperature: $17^{\circ} \mathrm{C}$

\section{SAMPLE}

1

2

3

4

6
TEMP ${ }^{\circ} \mathrm{C}$

19.545

19.60

19.685

19.76

19.96

20.075
DEPTH M

25
30
35
40
45
45.3

Well: TG-2

Location: (C-43-15)7bbb

Site Elevation: $775 \mathrm{~m}$

Ambient Temperature: $9^{\circ} \mathrm{C}$

SAMPLE
1
2
3
4
5
6
7
8
9
10
11
12
13
14
15
16

TEMP ${ }^{\circ} \mathrm{C}$
18.485
18.27
18.035
18.01
17.99
17.97
17.955
17.94
17.925
17.915
17.91
17.91
17.93
17.96
17.965
17.995

DEPTH M

11.8

16.8

21.8

26.8

31.8

36.8

41.8

46.8

51.8

56.8

61.8

66.8

71.8

76.8

81.8

86.5

Well: TG-3

Location: (C-43-15)11ddd

Site Elevation: $845 \mathrm{~m}$

Depth Interval for Calculated Gradient: 80.7-125.7 m

Calculated Gradient: $21.8 \pm 0.4^{\circ} \mathrm{C} / \mathrm{km}$

Ambient Temperature: $17^{\circ} \mathrm{C}$

SAMPLE
1
2
3
4
5
6
7
8
9
10

TEMP $^{\circ} \mathrm{C}$
21.035
20.365
20.005
19.785
19.655
19.65
19.66
19.965
19.74
19.79

DEPTH M

15.7

20.7

25.7

30.7

35.7

40.7

45.7

50.7

55.7

60.7 


\begin{tabular}{ccc}
\hline & Table 4. Continued. \\
\hline 11 & 19.835 & \\
12 & 19.885 & 65.7 \\
13 & 19.935 & 70.7 \\
14 & 19.99 & 75.7 \\
15 & 20.095 & 80.7 \\
16 & 20.255 & 85.7 \\
17 & 20.375 & 90.7 \\
18 & 20.54 & 95.7 \\
19 & 20.62 & 100.7 \\
20 & 20.72 & 105.7 \\
21 & 20.80 & 110.7 \\
22 & 20.92 & 115.7 \\
23 & 20.92 & 120.7 \\
& & 125.7
\end{tabular}

Well: $\mathbf{T G}-4$

Location: (C-43-15)25ddd

Site Elevation: 850 m

Ambient Temperature: $20^{\circ} \mathrm{C}$

SAMPLE

1

2

3

4
TEMP ${ }^{\circ} \mathrm{C}$

17.335

17.26

17.255

17.255

17.255
DEPTH M

29.4

34.4

39.4

44.4

48.3

Well: TG-5

Location: (C-43-15)24dec

Site Elevation: 875 m

Depth Interval for Calculated Gradient: 88.9-133.9 m

Calculated Gradient: $22.3 \pm 0.4^{\circ} \mathrm{C} / \mathrm{km}$

Ambient Temperature: $19^{\circ} \mathrm{C}$

SAMPLE

1

2

3

4

5

6

7

8

9

10

11

12

13

14

15

16

17

18

19

20

21
TEMP ${ }^{\circ} \mathrm{C}$

19.10

19.16

19.185

19.21

19.245

19.29

19.36

19.425

19.525

19.60

19.70

19.80

19.93

20.05

20.15

20.275

20.375

20.485

20.59

20.65

20.65
DEPTH M

43.9

48.9

53.9

58.9

63.9

68.9

73.9

78.9

83.9

88.9

93.9

98.9

103.9

108.9

113.9

118.9

123.9

128.9

133.9

138.9

143.9 
Table 4. Continued.

Well: TG-6

Location: (C-40-16)8bbc

Site Elevation: $925 \mathrm{~m}$

Ambient Temperature: $16^{\circ} \mathrm{C}$

\section{SAMPLE}

1

2

3

4

5

6

7

8

9

10

11

12

13

14

15

16

17

18

19

20

21

22

23

24

25

26

27

28

29

30

31

32

33

34

35

36

37

38

39

40

41

42

43

44
TEMP ${ }^{\circ} \mathrm{C}$

27.52

35.80

40.49

44.79

45.81

46.67

47.92

48.26

49.01

50

51.25

52.32

53.36

54.35

55.24

56.14

56.88

57.64

58.43

59.38

60.26

61

61.71

62.71

63.30

64.18

64.68

65.41

65.97

66.66

67.13

67.58

67.82

68.02

68.22

68.45

68.37

68.53

68.69

68.82

68.97

69.13

69.28

69.46

69.60
DEPTH M

24

49

74

99

104

109

114

119

124

129

134

139

144

149

154

159

164

169

174

179

184

189

194

199

204

209

214

219

224

229

234

239

244

249

254

259

264

269

274

279

284

289

294

299

304

Well: TG-7

Location: (C-43-14)17edd

Site Elevation: $925 \mathrm{~m}$

Depth Interval for Calculated Gradient: 43.9-161.9 m

Calculated Gradient: $19.3 \pm 0.7^{\circ} \mathrm{C} / \mathrm{km}$

Ambient Temperature: $22^{\circ} \mathrm{C}$

SAMPLE

1
TEMP ${ }^{\circ} \mathrm{C}$

19.825

19.865
DEPTH M

43.9

48.9 
Table 4. Continued.

\begin{tabular}{rcc}
\hline 3 & 19.95 & \\
4 & 20.135 & 53.9 \\
5 & 20.225 & 58.9 \\
6 & 20.31 & 63.9 \\
7 & 20.425 & 68.9 \\
8 & 20.51 & 73.9 \\
9 & 20.735 & 78.9 \\
10 & 20.775 & 83.9 \\
11 & 20.83 & 88.9 \\
12 & 20.885 & 93.9 \\
13 & 20.865 & 98.9 \\
14 & 20.99 & 103.9 \\
15 & 21.10 & 106.4 \\
16 & 21.11 & 108.9 \\
17 & 21.12 & 113.9 \\
18 & 21.265 & 118.9 \\
19 & 21.385 & 123.9 \\
20 & 21.395 & 128.9 \\
21 & 21.595 & 133.9 \\
22 & 21.67 & 136.4 \\
23 & 21.835 & 138.9 \\
24 & 21.92 & 143.9 \\
25 & 22.025 & 148.9 \\
26 & 22.08 & 153.9 \\
27 & 22.08 & 158.9 \\
& & 161.9
\end{tabular}

Well: TG-8

Location: (C-42-13)33aad

Site Elevation: $1035 \mathrm{~m}$

Depth Interval for Calculated Gradient: $139-161 \mathrm{~m}$ Calculated Gradient: $18.5 \pm 0.2^{\circ} \mathrm{C} / \mathrm{km}$

Ambient Temperature: $17^{\circ} \mathrm{C}$

SAMPLE
1
2
3
4
5
6

TEMP $^{\circ} \mathrm{C}$
19.43
19.50
19.635
19.745
19.79
19.82

DEPTH M

139

144

149

154

159

161

Well: TG-9

Location: (C-42-13)7beb

Site Elevation: $900 \mathrm{~m}$

Ambient Temperature: $23^{\circ} \mathrm{C}$

SAMPLE
1
2
3
4
5
6
7
8
9
10
11
12
13

TEMP ${ }^{\circ} \mathrm{C}$
19.28
19.32
19.305
19.335
19.375
19.415
19.46
19.505
19.55
19.60
19.655
19.70
19.72

DEPTH M

11.2

16.2

21.2

26.2

31.2

36.2

41.2

46.2

51.2

56.2

61.2

66.2

71.2 
Table 4. Continued.

\begin{tabular}{ccc}
\hline 14 & 19.735 & 76.2 \\
15 & 19.77 & 81.2 \\
16 & 19.785 & 86.2 \\
17 & 19.785 & 91.2 \\
18 & 19.80 & 96.2
\end{tabular}

Well: TG-10

Location: (C-42-13)6bdb

Site Elevation: $905 \mathrm{~m}$

Ambient Temperature: $26^{\circ} \mathrm{C}$

SAMPLE

1

2

3

4

5

6

7

8

9

10

11
TEMP $^{\circ} \mathrm{C}$

21.21

21.32

21.66

22.125

22.31

22.385

22.45

22.50

22.545

22.58

22.60

22.615
DEPTH M

38.8

43.8

48.8

53.8

58.8

63.8

68.8

73.8

78.8

83.8

88.8

89.9

Well: TG-11

Location: (C-42-14)15aba

Site Elevation: 858 m

Ambient Temperature: $26^{\circ} \mathrm{C}$

SAMPLE

1

2

3

4
TEMP ${ }^{\circ} \mathrm{C}$

19.39

19.505

19.515

19.52

19.52

\section{DEPTH M}

30

35

40

45

47.5

Well: TG-12

Location: (C-42-14)15dbd

Site Elevation: 895 m

Depth Interval for Calculated Gradient: 19.5-27 m

Calculated Gradient: $33.7 \pm 0.2^{\circ} \mathrm{C} / \mathrm{km}$

Ambient Temperature: $25^{\circ} \mathrm{C}$

SAMPLE

1

2

3

4

5
TEMP ${ }^{\circ} \mathrm{C}$

15.88

16.455

17.225

17.51

17.671

17.765

\section{DEPTH M}

14.5

19.5

24.5 
Table 4. Continued.

Well: TG-13

Location: (C-42-13)18bbc

Site Elevation: $905 \mathrm{~m}$

Ambient Temperature: $26^{\circ} \mathrm{C}$

SAMPLE
1
2
3
4

TEMP ${ }^{\circ} \mathrm{C}$

19.675

19.675

19.675

19.685

DEPTH M

19.7

24.7

29.7

34.7

Well: TG-14

Location: (C-43-15)10cea

Site Elevation: 820 m

Ambient Temperature: $22^{\circ} \mathrm{C}$

\section{SAMPLE}

I

2

3

4

5

6

7

8

9

10

11

12

13
TEMP ${ }^{\circ} \mathrm{C}$

19.02

19.135

19.36

19.39

19.40

19.42

19.445

19.465

19.485

19.565

21.10

20.165

20.165
DEPTH M

18.5

23.5

28.5

33.5

38.5

43.5

48.5

53.5

58.5

63.5

66

68.5

Well: TG-15

Location: (C-43-15)12 bdd

Site Elevation: $845 \mathrm{~m}$

Ambient Temperature: $19^{\circ} \mathrm{C}$

\section{SAMPLE}

1

2

3

4

5

6

Well: TG-16

Location: (C-42-15)10bcd

Site Elevation: $925 \mathrm{~m}$

Ambient Temperature: $20^{\circ} \mathrm{C}$

\section{SAMPLE}

1

2
TEMP ${ }^{\circ} \mathrm{C}$

19.415

19.51

19.56

19.59

19.61

19.62

19.64
DEPTH M

19.6

24.6

29.6

34.6

39.6

44.6

49.3 
Table 4. Continued.

Well: TG-18
Location: (C-42-16)14daa
Site Elevation: $888 \mathrm{~m}$
Ambient Temperature: $16^{\circ} \mathrm{C}$

$\begin{array}{cc}\text { SAMPLE } & \text { TEMP }^{\circ} \mathbf{C} \\ 1 & 18.73 \\ 2 & 18.735 \\ 3 & 18.75 \\ 4 & 18.78 \\ 5 & 18.81 \\ 6 & 18.81 \\ 7 & 18.815 \\ 8 & 18.815 \\ 9 & 18.815 \\ 10 & 18.815 \\ 11 & 18.82 \\ 12 & 18.82 \\ 13 & 18.82 \\ 14 & 18.825 \\ 15 & 18.825 \\ 16 & 18.825 \\ 17 & 18.83 \\ 18 & 18.83 \\ 19 & 18.875\end{array}$

DEPTH M
25
30
35
40
45
50
55
60
65
70
75
80
85
90
95
100
105
110
115

\section{REFERENCES}

Arabasz, W. J., Smith, R. B., and Richins, W. D., eds., 1979, Earthquake studies in Utah, 1850 to 1978: University of Utah Seismograph Stations, Department of Geology and Geophysics, 548 p.

Armstrong, R. L., 1970, Geochronology of Tertiary igneous rocks, eastern Basin and Range Province, western Utah, eastern Nevada, and vicinity, U.S.A.: Geochimica et Cosmochimica Acta, v. 34, no. 2 p. 203-232.

Back, William, 1961, Techniques for mapping of hydrochemical facies in Geological Survey Research 1961: U.S. Geological Survey Professional Paper 424-D, p. D380-D382.

Best, M. G., and Brimhall, W. H., 1970, Late Cenozoic basalt types in the western Grand Canyon region in Hamblin, W. K., and Best, M. G., eds., Guidebook to the geology of Utah-the western Grand Canyon district: Utah Geological Society Guidebook to the Geology of Utah, no. 23, p. 57-74.

Best, M. G., and Brimhall, W. H., 1974, Late Cenozoic alkalic basaltic magmas in the western Colorado Plateaus and Basin and Range Transition Zone, U.S.A., and their bearing on mantle dynamics: Geological Society of America Bulletin, v. 85, no. 11, p. 1677-1690.

Best, M. G., and Hamblin, W. K., 1970, Implications of tectonism and volcanism in the western Grand Canyon in Hamblin, W. K., and Best, M. G., eds., Guidebook to the geology of Utah-the western Grand Canyon district: Utah Geological Society Guidebook to the Geology of Utah, no. 23, p. 75-79.

Best, M. G., and Hamblin, W. K., 1978, Origin of the northern Basin and Range province: Implications from the geology of its eastern boundary in Smith, R. B., and Eaton, G. P., eds., Cenozoic tectonics and regional geophysics of the western Cordillera: Geological Society of America Memoir 152 , p. $313-340$.

Bliss, J. D., 1983, Utah; basic data for thermal springs and wells as recorded in GEOTHERM: U.S. Geological Survey Open-File Report 83-437, 385 p.

Chapman. D. S., Blackwell, D. D., Parry, W. T., Sill, W. R., Ward, S. H., and Whelan, J. A., 1978, Regional heat flow and geochemical studies in southwest Utah: University of Utah, Department of Geology and Geophysics Final Report, v. 2, contract no. 14-08-0001-G-341, 118 p.

Christensen, G.E., and Deen, R.D., 1983, Engineering geology of the St. George area, Washington County, Utah: Utah Geological and Mineral Survey Special Studies 58, 32 p.

Cook, E. F., 1960, Geologic atlas of Utah-Washington County: Utah Geological and Mineral Survey Bulletin 70, $124 \mathrm{p}$.

Cordova, R. M., 1978, Ground-water conditions in the Navajo Sandstone in the central Virgin River basin, Utah: Utah Department of Natural Resources Technical Publication, no. $61,66 \mathrm{p}$. 
Cordova, R. M., Sandberg, G. W., and McConkie, W., 1972, Ground-water conditions in the central Virgin River basin, Utah: Utah Department of Natural Resources Technical Publication, no. 40, 64 p.

Crook, J.K., 1899, The mineral waters of the United States and their therapeutic uses: New York and Philadelphia, Lea Brothers \& Co., $588 \mathrm{p}$.

Dobbin, C. E., 1939, Geologic structure of St. George district, Washington County, Utah: American Association of Petroleum Geologists Bulletin, v. 23, no. 2, p. 121-144.

Earth Sciences Associates, 1982, Phase I report-Seismic safety investigation of eight SCS dams in southwestern Utah: Earth Sciences Associates, Inc., Palo Alto, California, 48 p., 11 appendices.

Fournier, R. O., 1977, Chemical geothermometers and mixing models for geothermal systems: Geothermics, v. 5, p. 41-50.

Fournier, R. O., and Potter, R. W., 11, 1979, Magnesium correction to the $\mathrm{Na}-\mathrm{K}-\mathrm{Ca}$ chemical geothermometer: Geochemica et Cosmochimica Acta, v. 43, no. 9, p. 1543-1550.

Fournier, R. O., and Truesdell, A. H., 1974, Geochemical indicators of subsurface temperatures - Part 2, Estimation of temperature and fraction of hot water mixed with cold water: U.S. Geological Survey Journal of Research, v. 2, no. 3., p. 263-270.

Fournier, R. O., White, D. E., and Truesdell, A. H., 1974, Geochemical indicators of subsurface temperatures - Part 1, Basic assumptions: U.S. Geological Survey Journal of Research, v. 2., no. 3, p. 259-262.

Fournier, R. O., 1981, Application of water geochemistry to geothermal systems in Ryback, L., and Muffler, L. J. P., eds., Geothermal systems: principles and case histories: New York, John Wiley and Sons, p. 109-143.

Goode, H. D., 1978, Thermal waters of Utah: Utah Geological and Mineral Survey Report of Investigation 129, 183 p.

Gregory, H. E., 1950, Geology and geography of the Zion Park region, Utah and Arizona: U.S. Geological Survey Professional Paper 220, 200 p.

Hamblin, W. K., 1963, Late Cenozoic basalts of the St. George basin, Utah in Heylmun, E. B., ed., Guidebook to the geology of southwestern Utah-transition between basinrange and Colorado Plateau: Intermountain Association of Petroleum Geologists, Twelfth Annual Field Conference, p. 84-89.

Hamblin, W. K., 1965, Origin of "reverse drag" on the downthrown side of normal faults: Geological Society of America Bulletin, v. 76, no. 10, p. 1145-1164.

Hamblin, W. K., 1970a, Late Cenozoic basalt flows of the western Grand Canyon in Hamblin, W. K., and Best, M. $G$., eds., Guidebook to the geology of Utah-the western Grand Canyon district: Utah Geological Society Guidebook to the Geology of Utah, no. 23, p. 21-37.
Hamblin, W. K., 1970b, Structure of the western Grand Canyon region in Hamblin, W. K., and Best, M. G., eds., Guidebook to the geology of Utah-the western Grand Canyon district: Utah Geological Society Guidebook to the Geology of Utah, no. 23, p. 3-19.

Hamblin, W. K., 1986, Volcanic fields of the Veyo area, Utah: Brigham Young University Geology Studies Open-File Report Series, unpaginated.

Hamblin, W. K., in press, a, Geologic map of the Hurricane 15-minute quadrangle, Washington County, Utah: U.S. Geological Survey GQ Map Series, scale 1:62,500.

Hamblin, W. K., in press, b, Geologic map of the St. George 15-minute quadrangle, Washington County, Utah: U.S. Geological Survey GQ Map Series, scale 1:62,500.

Hamblin, W. K., Damon, P. E., and Bull, W. B., 1981, Estimates of vertical crustal strain rates along the western margins of the Colorado Plateau: Geology, v. 9, no. 7, p. 293-298.

Hem, J. D., 1970, Study and interpretation of the chemical characteristics of natural water: U.S. Geological Survey Water-Supply Paper 1473, 363 p.

Kappelmeyer, O., and Haenel, R., 1974, Geothermics with special reference to application: Berlin, Gebruder Borntraeger, $238 \mathrm{p}$.

Lachenbruch, A. H., and Sass, J. H., 1978, Models of an extending lithosphere and heat flow in the Basin and Range province in Smith, R. B., and Eaton, G. P., eds., Cenozoic tectonics and regional geophysics of the western Cordillera: Geological Society of America Memoir 152, p. 209-250.

Lachenbruch, A. H., and Sass, J. H., 1980, Heat flow and energetics of the San Andreas fault zone: Journal of Geophysical Research, v. 85, no. B11, p. 6185-6222.

Laughlin, A. W., 1982, Exploration for geothermal energy in Edwards, L.M., Chilingar, G.V., Rieke, H.H. III, and Fertl, W.H., eds., Handbook of Geothermal Energy: Houston, Gulf Publishing Company, p. 229.

Lumb, J. T., 1981, Prospecting for geothermal resources in Ryback, L., and Muffler, L. P. J., eds., Geothermal systems: principles and case histories: New York, John Wiley and Sons, p. 77-108.

Macdonald, G. A., and Katsura, T., 1964, Chemical composition of Hawaiian lavas: Journal of Petrology, v. 5, pt. 1, p. 82-133.

Mundorff, J. C., 1970, Major thermal springs of Utah: Utah Geological and Mineral Survey Water Resources Bulletin $13,60 \mathrm{p}$.

Murphy, P. J. compiler, 1980, Geothermal Resources of Utah, 1980: Map prepared by the National Oceanic and Atmospheric Administration for the U.S. Department of Energy, scale 1:500,000.

Peale, A. C., 1886, Lists and analyses of the mineral springs of the United States: U.S. Geological Survey Bulletin 32, 235 p. 
Petersen, S. M., 1983, The tectonics of the Washington fault zone, northern Mohave County, Arizona: Brigham Young University Geology Studies, v. 30, pt. 1, p. 83-94.

Proctor, P. D., 1953, Geology and ore deposits of the Silver Reef (Harrisburg) mining district, Washington County, Utah: Utah Geological and Mineral Survey Bulletin 44, 169 p.

Reed, M. J., 1983, Introduction in Reed, M. J., ed., Assessment of low-temperature geothermal resources of the United States-1982: U.S. Geological Survey Circular 892 , p. 1-8.

Rowley, P. D., and Barker, D. S., 1978, Geology of the Iron Springs mining district, Utah inShawe, D. R., and Rowley, P. D., eds., Field excursion C-2-Guidebook to mineral deposits of southwestern Utah: Utah Geological Association Publication 7, p. 49-58.

Sandberg, G. W., and Sultz, L. G., 1985, Reconnaissance of the quality of surface water in the upper Virgin River basin, Utah, Arizona, and Nevada, 1981-82: Utah Department of Natural Resources Technical Publication, no. 83, 69 p.

Stokes, W. L., 1977, Subdivisions of the major physiographic provinces in Utah: Utah Geology, v. 4, no. 1, p. 1-7.

Withrow, Carol, 1983, ELE an elemental analysis program, a user's guide to version 2.1: Earth Science Laboratory/University of Utah Research Institute Report, no. ESL 501, 28 p.

Yoder, H. S., Jr., and Tilley, C. E., 1962, Origin of basalt magmas; an experimental study of natural and synthetic rock sytems: Journal of Petrology, v. 3, pt. 3, p. 342-532. 


\title{
UTAH GEOLOGICAL AND MINERAL SURVEY
}

\author{
606 Black Hawk Way \\ Salt Lake City, Utah 84108-1280
}

THE UTAH GEOLOGICAL AND MINERAL SURVEY is one of eight divisions in the Utah Department of Natural Resources. The UGMS inventories the geologic resources of Utah (including metallic, nonmetallic, energy, and ground-water sources); identifies the state's geologic and topographic hazards (including seismic, landslide, mudflow, lake level fluctuations, rockfalls, adverse soil conditions, high groundwater); maps geology and studies the rock formations and their structural habitat; and provides information to decisionmakers at local, state, and federal levels.

THE UGMS is organized into five programs. Administration provides support to the programs. The Economic Geology Program undertakes studies to map mining districts, to monitor the brines of the Great Salt Lake, to identify coal, geothermal, uranium, petroleum and industrial minerals resources, and to develop computerized resource data bases. The Applied Geology Program reponds to requests from local and state governmental entities for site investigations of critical facilities, documents, responds to and seeks to understand geologic hazards, and compiles geologic hazards information. The Geologic Mapping Program maps the bedrock and surficial geology of the state at a regional scale by county and at a more detailed scale by quadrangle.

THE INFORMATION PROGRAM distributes publications, and answers inquiries from the public and manages the UGMS Library. The UGMS Library is open to the public and contains many reference works on Utah geology and many unpublished documents about Utah geology by UGMS staff and others. The UGMS has begun several computer data bases with information on mineral and energy resources, geologic hazards, and bibliographic references. Most files are not available by direct access but can be obtained through the library.

THE UGMS PUBLISHES the results of its investigations in the form of maps, reports, and compilations of data that are accessible to the public. For future information on UGMS publications, contact the UGMS sales office, 606 Black Hawk Way, Salt Lake City, Utah 84108-1280 


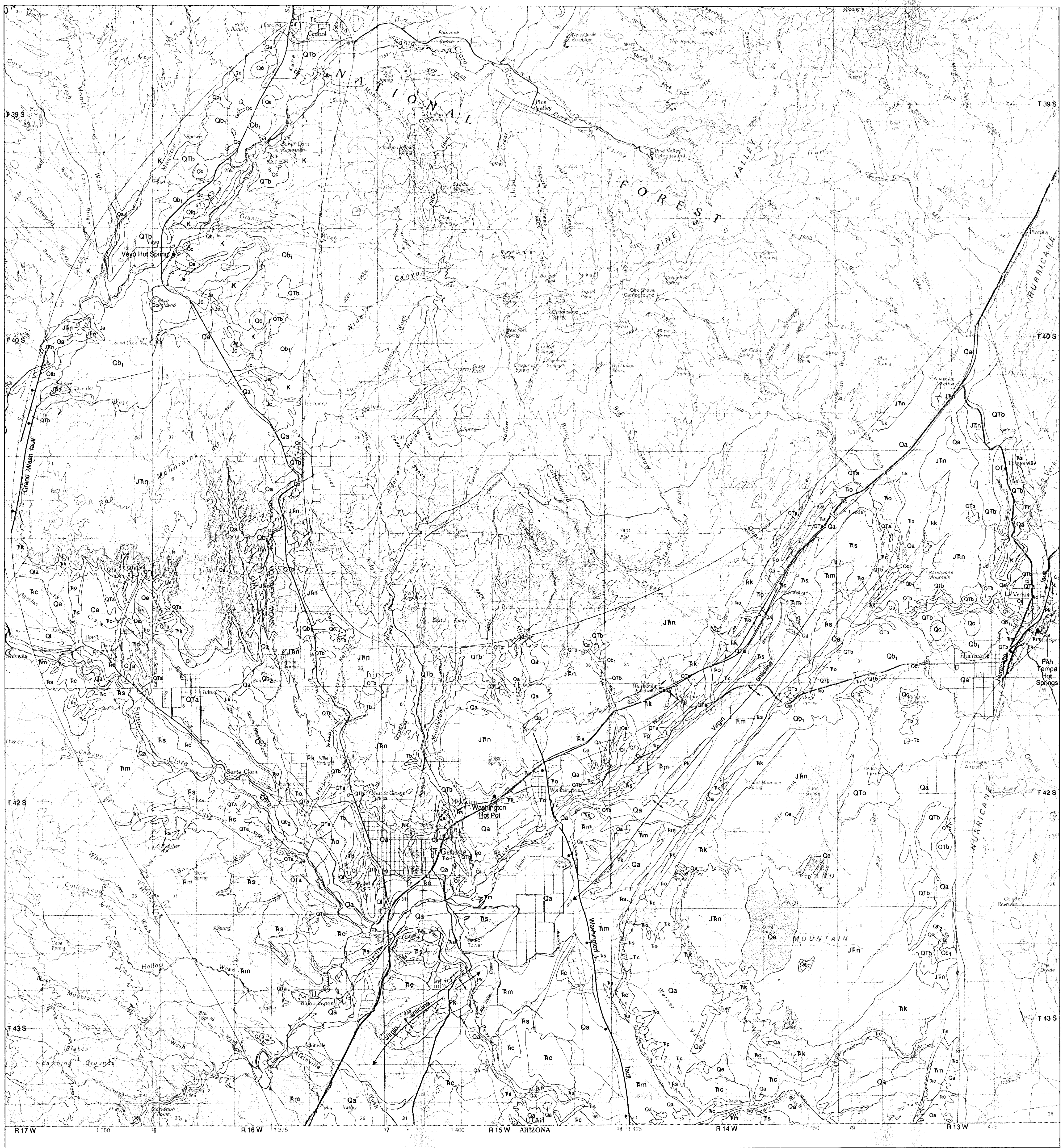

Plate 1

GEOLOGIC MAP OF THE

ST. GEORGE BASIN

Modified from Hamblin

(1986; in press $a$ and $b$ )

and Cook (1960)

DESCRIPTION OF MAP UNITS

SEDMENTARY ROCKS

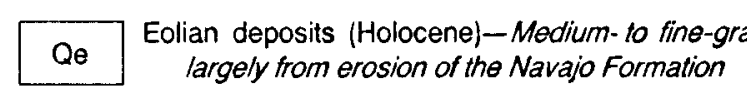

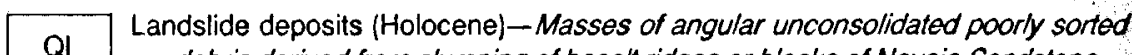

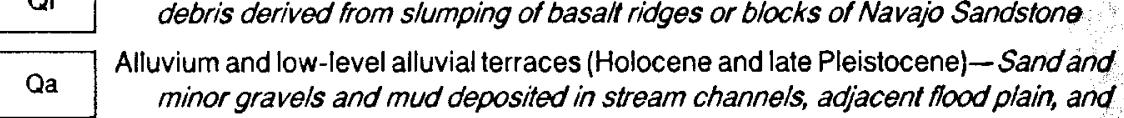

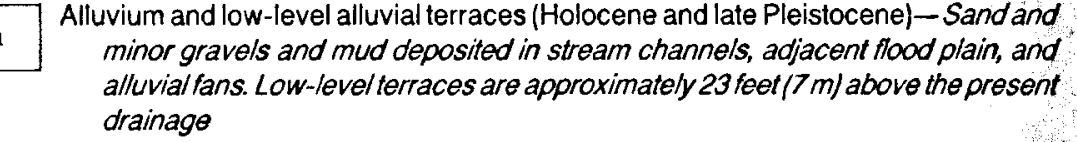

OTa

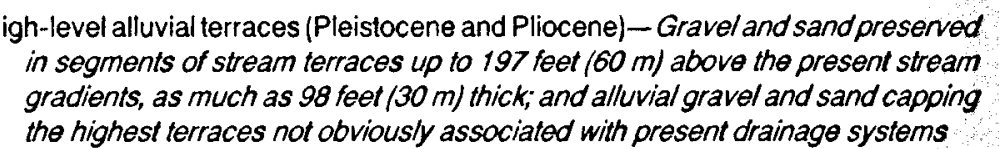

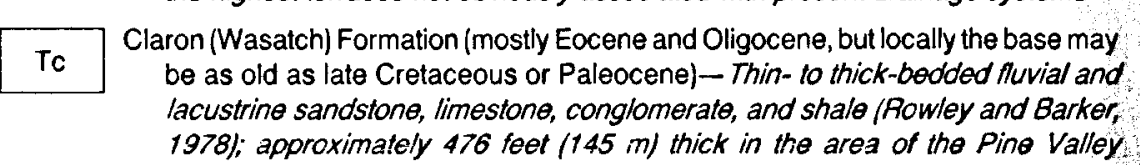

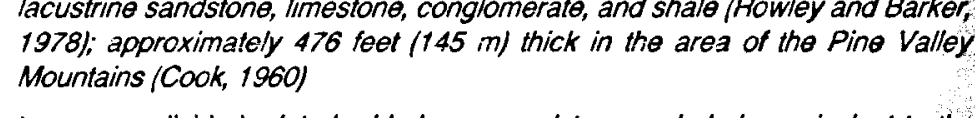

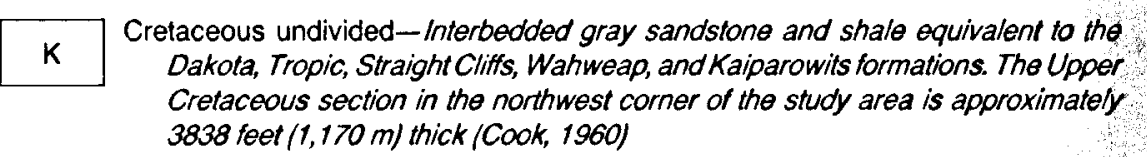

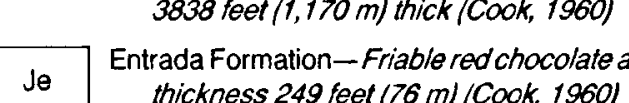

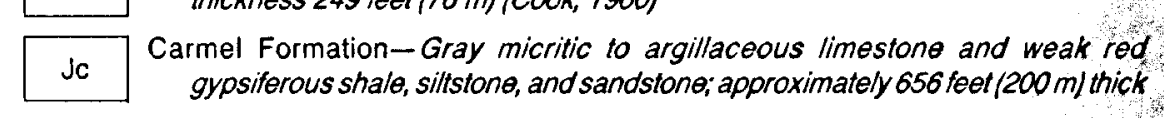

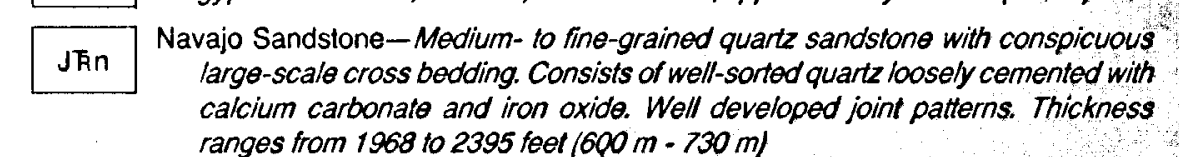

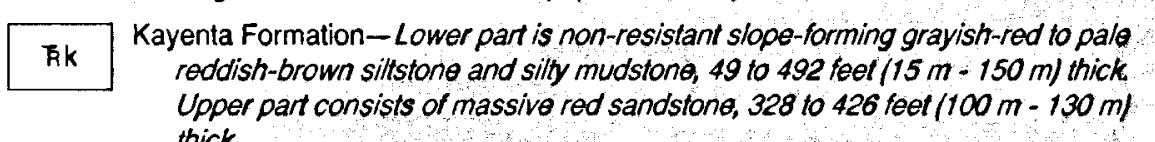

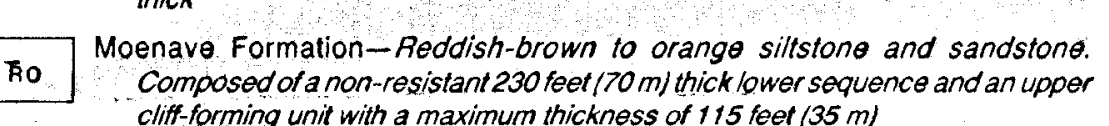

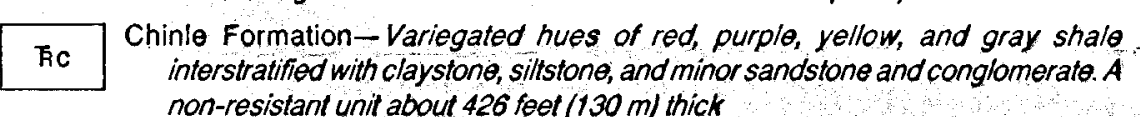

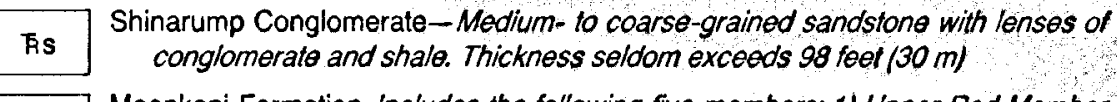

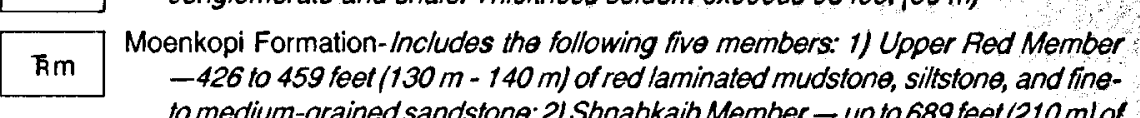

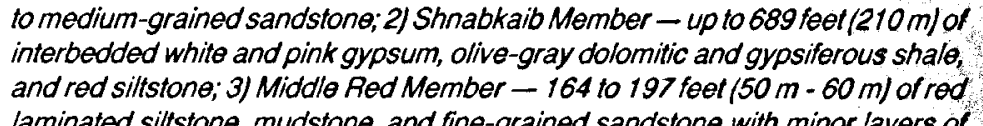

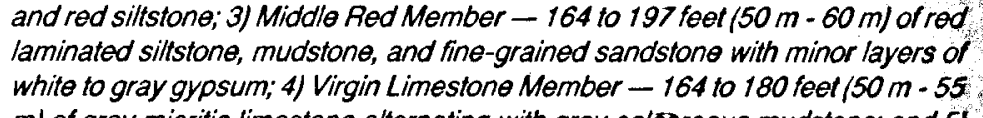

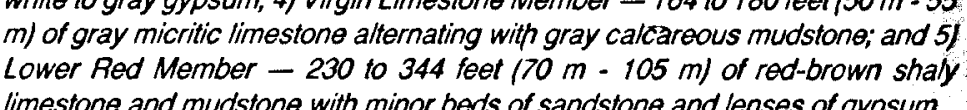

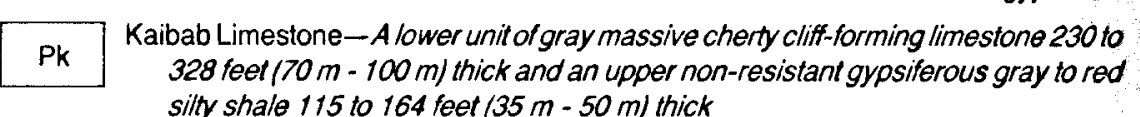

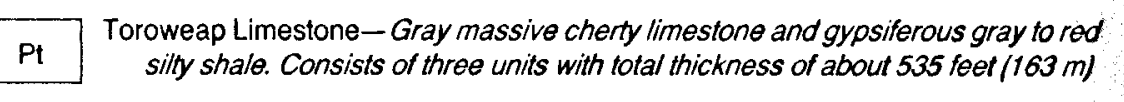
IGNEOUS ROCKS

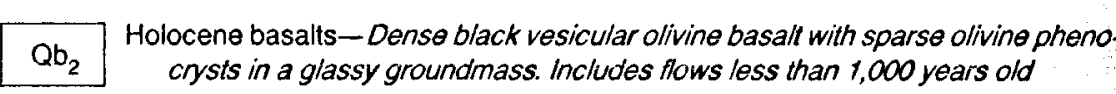

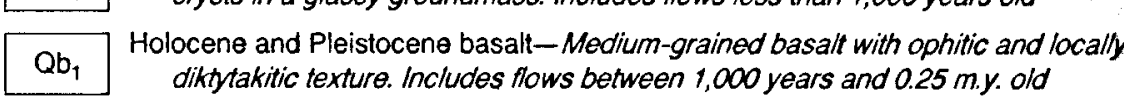

Qc Volcanic cinders Holocenen and Pleistocenene)-Basathic cinder cones

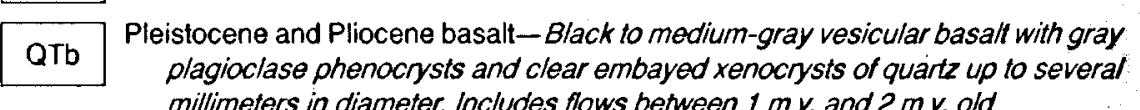

$\mathrm{Tb}^{\mathrm{Te}}$

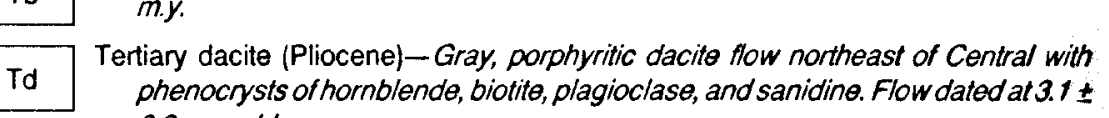
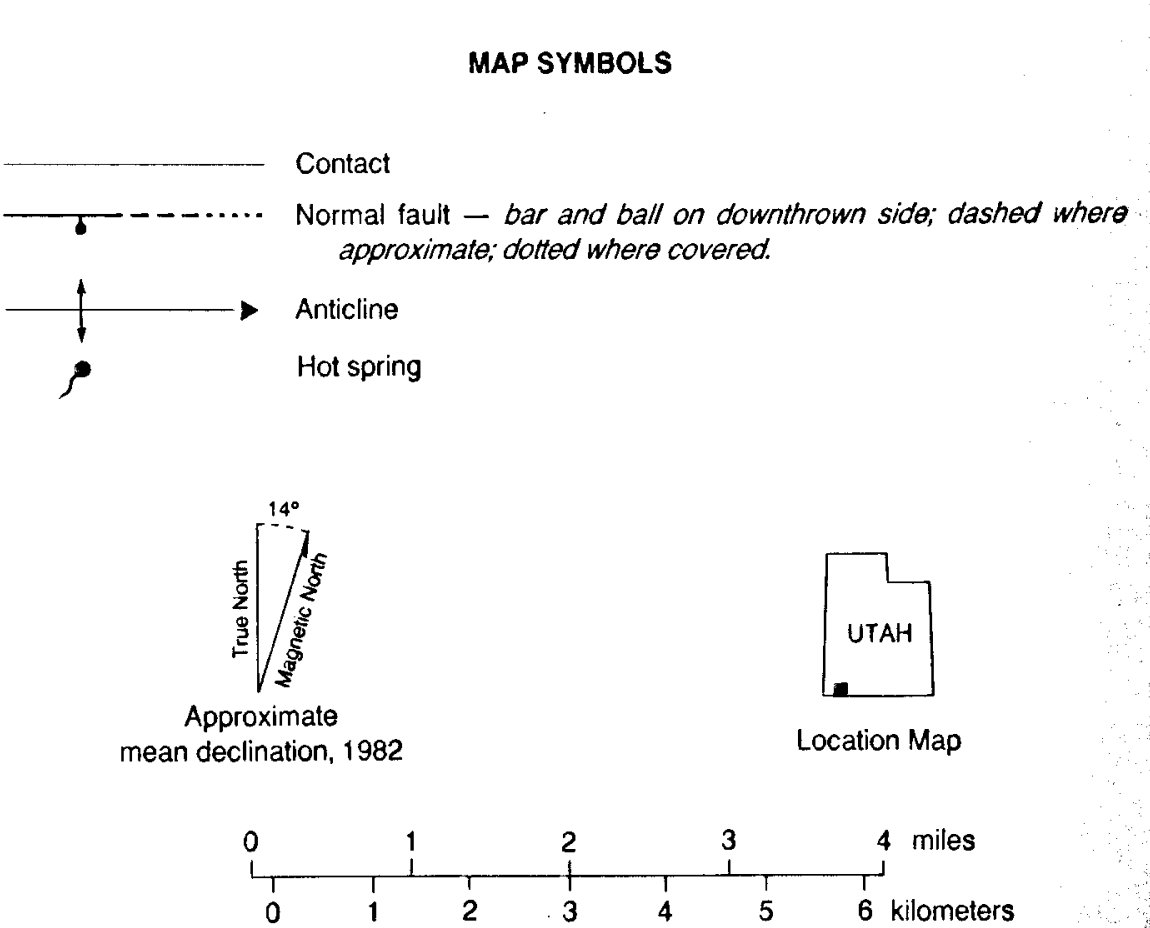